\title{
LAURENCE STERNE AND THE TRADITION OF CHRISTIAN FOLLY
}

By

BYRON PETRAKIS

\begin{abstract}
A DISSERTATION PRESENTED TO THE GRADUATE COUNCLL OF TIIE UNIVERSITY OF FLORIDA

IN PARTIAL FULFILLMENT OF THE REQUIREMLNTS FOR TIE DEGREE OF DOCTOI OF P'IHLOSOPHY
\end{abstract}



Copyright by Byron Petrakis 1968 


\section{Acknowledgments}

It is a pleasure to acknowledge the assistance which I have received from the members of my supervisory committee, Professor George M. Harper, and Professor E. Ashby Hammond.

To Professor Thomas R. Preston, under whose guidance this dissertation was begun, I owe the debt of inspiration and encouragement. To Professor Aubrey L. Williams, I owe the debt of the scholarly example and patient criticism which enabled me to complete this dissertation.

Finally, I thank my wife, Gayle, for loving me enough to avoid Mrs. Shandy's error of giving her "assent and consent to any proposition" which her husband "laid before her." 
Preface

The subject of this study is Sterne's use of the Pauline concept of Christian folly: that is, that wisdom in the eyes of the world may be folly in the eyes of God, while folly in the eyes of the world may lead to wisdom in the eyes of God. My thesis is that the various aspects of the concept of Christian folly which appear. throughout Sterne's work reflect traditional Christian attitudes toward what this world calls wisdom and folly. Focusing particularly on Tristram Shandy, I argue that several of the characters in the novel personify various aspects of wisdom and folly, ranging from Walter Shandy's obsession with worldly-wise hypotheses to Parson Yorick's apparently "foolish" martyrdom to truth, and that the novelistpreacher Sterne accomplishes a transvaluation of the terms "wisdom" and "folly." Because Sterne's employment of the concept of Christian folly is rooted in earlier treatments of the idea of the wise fool in Christ, Chapter I of this study traces the history of the Idea of Christian folly from the Middle Ages through the seventeenth century. Chapter I shows how early Fathers of the Church and medieval mystics such as Thomas à Kempis shaped the idea of Christian folly into two related, yot distinct strands. For members of what Etienne Gilson has called the "Tertullian family," Christian folly took the form of intellectual humility in order to combat the challenge of gnosticism, while for members of the "Augustine family," notably St. 
Augustine and Nicholas of Cusa, Christian folly took the form of "learned ignorance" in order to meet the challenge of scholasticism. With the advent of the Renaissance, and the work of the great Christian humanists, Erasmus and Rabelais, the idea of the wise fool in Christ leaves the confines of Biblical commentary and polemical theology, and enters the realm of imaginative literature. The wise fools in Christ, praised by the medieval Church Fathers as personifications of a theological idea or concept, become in the works of Erasmus and Rabelais drematis personae, capable of acting as court jesters, receptacles of divine truth, enemies of the proud and worldly wise, and exemplars of charity and humility. In the person of Sir Thomas More, these various facets of Christian folly combined to give to the Renaissance and the world a living example of how folly in the eyes of men leads to wisdom in the eyes of God. At the conclusion of the Renaissance and up to the eighteenth century, the idea of Christian folly was most evident in the form of Biblical commentaries and sermons upon Pauline texts by Anglican divines, such as Henry Hammond and Robert South.

Chapter II shows how the idea of Christian folly which appears in Tristram Shandy is related to traditional Christian views of not only the dangers resulting from man's obsession with worldly wisdom, but also the temporal and spiritual benefits accruing from man's recognition of his own foolishness. More specifically, Chapter II attempts to demonstrate that the characters in Tristram Shandy comprise 
a catalogue of fools, whose "folly" is sometimes "wisdom," depending upon the perspective of the viewer. Because Sterne views Solomon's observation that "the number of fools is infinite" from the sympathetic point of view of Erasmian irony, he ridicules folly in Tristram Shandy instead of inveighing against it in the manner of some of his Augustan predecessors. While Sterne's narrator, Tristram, exposes the foolishness of the novel's worldly wise men, particularly his father's obsession with speculative hypotheses, he exhibits an Erasmian perspective on human folly by himself speaking as a fool. Parson Yorick, Tristram's more "foolish," but paradoxically "wiser," counterpart, complements Tristram's satire upon worldly wisdom by exposing the foolishness of "vile canonists" and "polemic divines." In ridiculing the pretensions and shortcomings of his clerical colleagues, Yorick also reveals himself as "a man of infinite jest" and as a model of Christian humility and charity, thereby personifying several of the virtues eulogized by Renaissance praisers of folly.

Chapter III shows how Toby and Trim, often dismissed as ineffectual simpletons or amusing eccentrics, illustrate the Pauline paradox that "God hath chosen the foolish things of the world to confound the wise; and... the weak things of the world to confound the things which are mighty" (I Cor. 1.27). More particularly, the first section of Chapter III attempts to demonstrate that Tristram's uncle, Toby, functions as an unlearned instrument of divine wisdom and resembles the "natural" fools praised by the medieval Fathers of 
the Church for their Christ-like simplicity and charity. Functioning as a foil to the worldly wisdom of the novel's pedants, Toby also exemplifies the Christian virtues of charity, humility, and trust in divine providence, which Sterne expresses in The Sermons of Mr. Yorick. The second section of Chapter III attempts to demonstrate that Corporal Trim, as seen particularly in his funeral oration upon Bobby's death, is Sterne's projection of the ideal preacher. Dramatizing the essence of Sterne's concept of preaching, a direct appeal to the heart, Trim rejects both the affectations of pre-Restoration pulpit eloquence and the emotionless severity of the Restoration pulpit. Speaking in the rich, but unaffected, language of the Scriptures, Trim demonstrates to the Shandeans the wisdom of what St. Paul called "the folly of preaching" (I Cor。1.21)。

Chapter IV shows how Parson Yorick's Christian folly, in both Tristram Shandy and A Sentimental Journey, is the highest manifestation of wise folly which appears in Sterne's writings. Sterne's allusions to Hamlet and Don Quixote, throughout Volume I of Tristram Shandy, provide a context for establishing Yorick's Christian folly as a norm to test the various kinds of worldly wisdom represented in the novel. Although Tristram praises Yorick's quixotic martyrdom to truth in Volume I of Tristram Shandy, he also blames his "Hero" for his lack of discretion and prudence. Corresponding to his wavering, as a narrator, between praise and blame for Yorick's Christian folly, is Tristram's failure, as a character, to achieve the perfect wisdom of Yorick's Christian folly. Chapter IV also shows how Yorick's wise folly in Christ becomes evident in his similarity to Paul's "New Man," who 
represents the Christian fool's joyful vision of death as the beginning of life. In contrast, Tristram, like Paul's "Old Man," subverts the moral and spiritual imperative of man's journey through this world to the next by foolishly attempting to outrace Death in Volume VII of Tristram Shandy. The "Sentimental Traveller" Yorick of A Sentimental Journey concludes the program of wise folly in Christ which Sterne presents throughout his writings.

My prefatory remarks would be incomplete without an acknowledgment of my indebtedness to Walter Kaiser's Praisers of Folly, which introduced me to the study of the wise fool in Christ. I am also generally indebted to John Traugott's Tristram Shandy's World, John Stedmond's The Comic Art of Laurence Sterne, and Gardner D. Stout, Jr. 's edition of A Sentimental Journey Through France and Italy by Mr. Yorick for pointing out ways in which Sterne's use of the idea of Christian folly could be developed and discussed. 
Contents

Acknowledgments iil

Preface iv

One The Tradition of Christian Folly I

Two The Folly of Wisdom 43

Three The Wisdom of Folly 78

Four The Transcendent Wisdom of Yorick's

Christian Folly 122

$\begin{array}{ll}\text { Works Cited } & 177\end{array}$ 


\section{One: The Tradition of Christian Folly}

In his sermon "Advantages of Christianity to the World," based upon Romans 1.22 ("Professing themselves to be wise, they became fools"), Laurence Sterne states that the wisdom of the learned Greeks and Romans was "specious" and nothing "but a more glittering kind of ignorance." I In "Our Conversation $/$ in Heaven," whose text is Phillipians 3.20 ("For our conversation is in heaven; from whence also we look for the Saviour, the Lord Jesus Christ"), Sterne encourages his readers to follow the example of St. Paul, who "accounted all things but loss, that is, less than nothing, for the excellency of the knowledge of Jesus Christ" (Sermons, II, 93). These two quotations from The Sermons of Mr. Yorick illustrate a Pauline concept or idea which may be called "Christian folly." The essence of the idea of Christian folly is Paul's teaching that the truly wise man rejects this world's wisdom and becomes "a fool for Christ's sake" (I Cor. 4.10). "The wisdom of this world is foolishness with God" (I Cor. 3.19), argues Paul, and "the foolishness of God is wiser than men" (I Cor. 1.25).

Expressed in various forms from the time of St. Paul, the idea of Christian folly became a common place tradition in the Middle Ages. ${ }^{2}$ For one large group of writers, hereafter called the "Tertullian family, ${ }^{3}$ Christian folly demands that man imitate Cnrist's 
meekness and humility and sacrifice his reason before God's omniscience. For these praisers of Christian folly, including Tertullian, Saints Jerome and Gregory, and the medieval mystics, Jacapone da Todi and Thomas à Kempis, the idea of Christian folly is closely Iinked to the idea of contemptus mundi. Writing in the fifteenth century, Kempis, for example, instructs man "to conform his whole life to that mind of Christ" so that he may "willfully and with true wisdom understand the words of Christ" (Imitatio, 1.1.4). 4 By imitating Christ, Kempis argues, man will learn that the highest form of wisdom is to "despis $[e]$. . this world [and] to draw daily nearer and nearer to the kingdom of heaven" (Imitatio, 1.1.4).

In contrast to the version of Christian folly advocated by the "Tertullian family," the members of the "Augustine family," including St. Augustine and Nicholas of Cusa, do not instruct man to renounce all wisdom, but only to reject those kinds of worldly wisdom which might prevent him from achieving the wisdom of Christ. In a letter, Augustine wrote that "wisdom is not to be avoided because there is also false wisdom, to which Christ crucified is foolishness." 5 For Augustine, and his intellectual heir, Nicholas of Cusa, the paradoxical phrase "knowing ignorance" (docta ignorantia) expresses the proper relation between human and divine wisdom. "There is in us a certain knowing ignorance," Augustine writes, but it is "an ignorance taught by the spirit of God which comes to the help of our weakness" (Fathers, XVIII, 398)。 Exhibiting a kinship to the members of the "Augustine family," who taught that man should not renounce the world 
so much as the wisdom of the world, the Renaissance humanists, Erasmus and Rabelais, encouraged man's participation in the God-given joys of creation and urged a rejection of only those kinds of wisdom which prevented him from becoming a fit receptacle for the wisdom of Christ. In a letter to Martin Dorp, who is called Erasmus" "first critic," 6 Erasmus said about The Praise of Folly, that "to be ignorant of certain things is a part of knowledge. "7

As I hope to show, the idea of Christian folly appearing throughout Sterne's work is more simflar to the AugustinianRenaissance version than to the Tertullian-medieval version of the idea of Christian folly. As Sterne states in his sermon "Penances," one of the "many prejudices which at one time or other have been conceived against our holy religion.. Iis that it is our duty . . to renounce the world, and abstract ourselves from it, as neither to interfere with its interest, or taste any of the pleasures, or any of the enjoyments of this life" (Sermons, II, 175). For Sterne, as for William Wycherley, in his poem "Upon the Discretion of Folly," the Christian fool is happy in this world and the next:

Thus Fools are here, as likewise thought elsewhere, But for their want of Thought much happier Which is most Wisdom: Heav'nly Wisdom, whence Men have their Faith, their Truth, and Innocence; Whence Heav'n to Fools wise Turks in next Life give; But Christian Fools are happy whilst they live.

As the persona Stultitia observes in Erasmus' The Praise of Folly, the Pauline paradox that human wisdom is foolishness with God 
is rooted in 0ld Testament condemnations of the vanity of human learning. In the concluding section of her oration, Stultitia quotes extensively from various old Testament writers who maintain that, in the final analysis, man's wisdom is folly in the eyes of God. Following the rhetorical practice of quoting authorities, Stultitia ironically argues that all wisdom is folly:

In his tenth chapter Jeremiah states.. 'Every man is made foolish in his own wisdom.' It is to God alone that he attributes wisdom, relegating foolishness to mankind. A little bit before this he says: 'Let no man glory in his wisdom' ... But let us turn again to Ecclesiastes. When he writes, 'Vanity of vanities, all is vanity,' what else does he mean other than ... that human life is nothing but a sport of folly?

Stultitia's transposition of the terms folly and wisdom early in her oration prepares the reader for her serious, concluding argument that the "Fool in Christ" is, in the eyes of God, the wisest of men. While St. Paul's epistles to the Corinthians echo Old Testament condemnations of the vanity of human learning, his identification of wisdom with Christ and Christ's suffering ${ }^{10}$ is, of course, a radical departure from Solomon's teaching that wisdom lies in fearing God and obeying His commandments. According to Earle Ellis, moreover, Paul's identification of wisdom with Christ and His suffering is also unique in terms of the New Testament:

There are no definite New Testament parallels with Paul's Wisdom typology in which Christ and His Cross are declared to be the true wisdom. But the apostle's several quotations (I Cor。1.19; 2.9,16; 3.19f) describing the vanity of the 'wisdom of this world' and its barren and foolish goal reflect somewhat the attitude of Christ: 'I thank thee, 0 Father, Lord of Heaven and earth, because thou hast hid these 
things from the wise and prudent and hast revealed them unto babes' (Mat. 11.25; Luke 10.21). The thought in each is that God reveals Himself not to the 'wise' but to the humble 11 and simple; Paul, of course, carries the theme much further.

Paul's rejection of vain human wisdom in favor of the wisdom of Christ does not, it should be noted, constitute a refutation of all wisdom other than Christian Revelation. 12 François Amiot reminds us that "Paul does not . . condemn reason itself but only its abuse and its refusal to accept supernatural enlightenment."13 Etienne Gilson points out, however, that there have been writers, such as Tertullian, St. Bernard, and Jacopone da Todi, who are "partisans of exclusive otherworldliness in the order of knowledge" (Gilson, p. 114). The contribution made by some of these "extremists in theology" (Gilson, p. 5) to the concept of Christian folly merits examination. Writing in the second century A.D., Tertullian, to use Gilson's words, expresses "absolute conviction in the self-sufficiency of Christian Revelation" (Gilson, p. 8). The concept of Christian folly which emerges from Tertullian's writings reflects a dichotomy between faith and reason, particularly as seen in passages from Tertullian against Marcion and The Body of Christ (De Carne Christi), where Tertullian argues that belief in the crucified Christ is sufficient for man's knowledge and salvation:

Since, then, the man... of this 7 world in his wisdom knew not God, whom indeed he ought to have known (both the Jew by his knowledge of the Scriptures, and all the human race by their knowledge of God's works), therefore that God, who was not acknowledged in His wisdom, resolved to smite men's knowledge with His foolishness, by saving all those who believe in the folly of the preached cross.14 
In its simplest terms, Christian folly appears in Tertullian as an act of faith in which the reason humiliates itself before the omniscience of God. 15 Tertullian's concept of faith as intellectual humility is clearly seen in his belief in the crucifixion because it is "absurd." The famous passage from De Carne Christi illustrates what James Edie calls Tertullian's concept of faith as "an experience of the absurd,"16 a "decision to act before one 'knows,' to act, if necessary, against the evidence, against the evident" (Edie, Christianity and Existentialism, p。29):

The Son of God was crucified; I am not ashamed because men must needs be ashamed of it. And the Son of God died; it is by all means to be believed, because it is absurd. 17

To Tertullian, man's only hope for salvation lies in rejecting philosophy, which he calls "the material of the world's wisdom, "I8 in favor of the wisdom of Christ. While such a choice results in man's being "a fool to the world," Tertullian argues, he paradoxically cannot be wise unless he does become a fool to the world by believing "the foolish things of God."19 One of "the foolish things of God Which7 is wiser than men," the Christian apologist explains in his tract against Marcion, is the "cross and death of Christ."20

It is no exaggeration, then, to say that Tertullian shapes the Pauline paradox central to the idea of Christian folly--that wisdom may lead to folly, and folly to wisdom--into a concept of intellectual humility which entails, to use George Boas's terms, "a sacrifice of human reason" (Boas, p. 121). Tertullian seems to demand this sacrifice so that man will grasp the paradox of Christian folly, and unlike the 
heretics and vain reasoners, understand why "God hath chosen the foolish things of the world to confound the wise" (I Cor. 1.27). ${ }^{21}$

St. Bernard and Jacopone da Todi are two members of the "Tertullian family" in whose works Christian folly appears in one form or another. Bernard, George Boas points out, "is... clearly in the tradition of Tertullian ... and seems indeed to be quoting the words of some of the] members" of the "Tertullian family" (Boas, p. 124). In a passage from De gradibus humilitatis et superbiae (On the Steps of Humility and Pride), Bernard distinguishes between various kinds of ignorance. "Not all ignorance is to be condemned," he says, "for there are... countless things which one may be ignorant of without lessening one's chance of salvation" (On the Steps of Humility and Pride, quoted by Boas, p. 124).

After explaining that ignorance of neither the "mechanical arts," such as carpentry, nor of the "liberal arts" of the university would impede one's chance of salvation, Bernard reminds his readers that

Peter and Andrew and the sons of Zebedee and all their fellow disciples were not taken from the schools of rhetoricians and philosophers, and none the less the Saviour through them wrought salvation upon the earth. Not in wisdom, which in them. was more than in all the living... but in their faith and meekness did He save them and make them saints and masters (On the Steps of Humility and Pride, quoted by Boas, pp. 124-25).

Jacopone da Todi, the Franciscan poet and mystic of the thirteenth century, was probably familiar with the works of St. Bernard, as he was with the writings of other medieval theologians, 
because of his studies at the convent of San Forunato. ${ }^{22}$ The first five verses of Jacopone's poem entitled "How it is the Highest Wisdom to be Reputed Mad for the Love of Christ" express a radical type of Christian folly analogous to both Tertullian's and Bernard's:

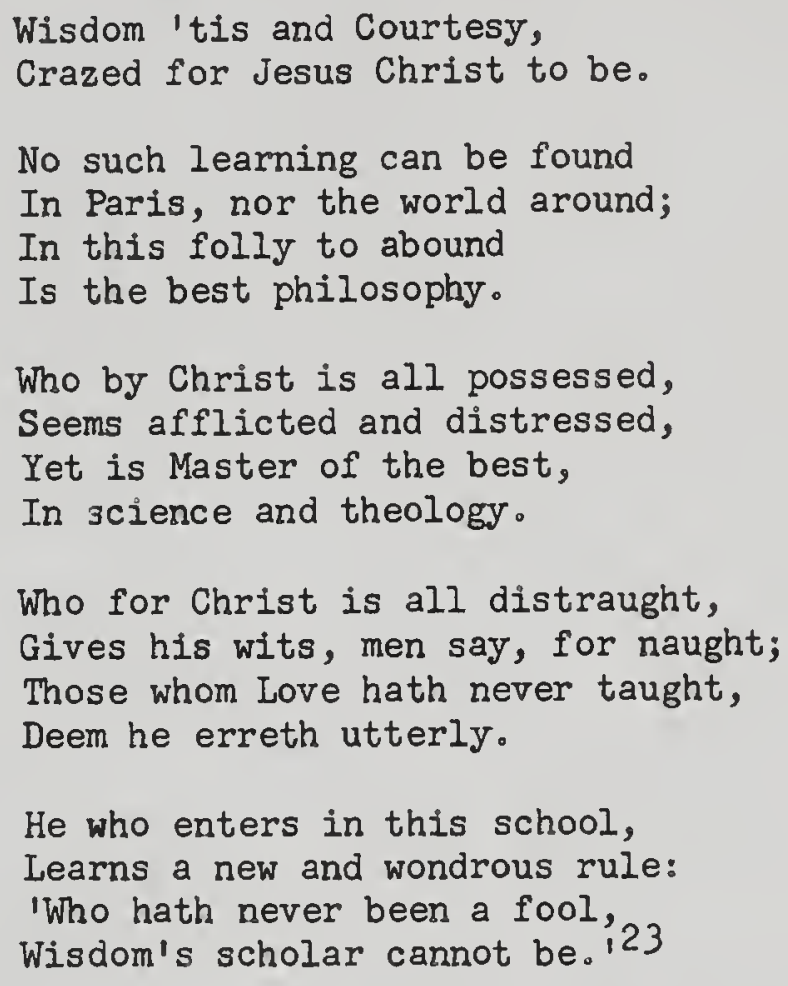

In another poem, which illustrates what Gilson calls the "radical theologism" of the Spirituals, an extremist group in the Franciscan Order (Gilson, p.13), Jacopone expresses a mistrust of philosophy similar to Tertullian's. For Jacopone, "only a pure and simple mind" can find its way "straight to heaven . . while far behind/Lags the world's philosophy" (quoted by Gilson, p. 13). Jacopone's stress upon the virtues of simplicity, purity, and humility may be traced back to the first chapter of First Corinthians. According to Evelyn Underhill, Jacopone's biographer, the "ruling 
conception of Jacopone's first period--that of the 'fool for Christ's sake'"--comes directly from St. Paul (Underhill, p. 227).

The Church Fathers Jerome and Gregory the Great, who may be classified as "distant relations" of the "Tertullian family," merit attention because their idea of Christian folly is less polemical than Tertullian's on the one hand, while still lacking, as we shall see, the sophistication of Augustine's and Cusa's, on the other. In his polemical tract The Dialogue Against the Pelegians, Jerome echoes the theme of intellectual humility which appears in the works of Jacopone and Thomas à Kempis. In discussing the gulf between worldly and divine wisdom, Jerome alludes to Ecclesiastes 1.18 to illustrate the orthodox argument that man "lacks perfection and realizes how much he does not know when he considers what he knows "(Fathers, LIII, 302). To Jerome, man attains wisdom by recognizing his own limitations and contrasting them to God's omnipotence. His commentary on Romans 16.27 in The Dialogue Against the Pelegians epitomizes his argument that man must be humble before God's wisdom: "God alone is wise, although both Solomon and many other holy men are called wise" (Fathers, LIII, 305). God's wisdom, moreover, manifests itself in His providential plan, and man's duty is to trust the wisdom of the divine architect:

We are God's tillage; we are God's building. According to His grace, God lays the foundation like a wise architect. 'Do not deceive yourselves,' he says. 'If any one of you thinks himself wise in this world, let him become a fool, that he may come to be wisel (Fathers, LIII, 307). 
Jerome expresses the concept of Christian folly not only in his polemical works, such as The Dialogue Against the Pelegians, but also in his commentaries on St. Paul's epistles. Jerome does not seek to denigrate worldly wisdom per se, but to indicate its pretentiousness and Iimitations. In his gloss of First Corinthians 3.18-19, he stresses Paul's condemnation of the Corinthians for claiming to be Christians while still clinging to worldly wisdom and the retributive justice of the old law:

If anyone thinks that he is wise because, for the sake of revenge, he has exacted an eye for an eye, let him be reckoned a fool. For, in the opinion, of this world, the fool is he who has tried to heed the teachings of the holy gospel; and the man who turns his other cheek to his attacker is a voluntary fool, but not a natural one.

No thing is as foolish as for one who is unable, to seek revenge himself and not to leave to God the /repaying/ of the wrong that has been done him. For thus will he the spiteful $\operatorname{man} 7$ lose the revenge of God for the wrong he has suffered, and, also, the reward of patience.24

Although the seeking of revenge is wisdom to the world, Jerome argues that it is foolishness before God. The man who willfully turns the other cheek is, in the world's eyes, "foolish," but since his voluntary action implements Christ's teaching, his "foolishness" will earn him justice in the court of God.

Jerome's contribution to the tradition of Christian folly, then, lies in his further emphasis on the humility, meekness, and charity of the fool for Christ. It is no coincidence that in his textual notes to the Vulgate Jerome suggests a comparison between First Corinthians 1.19 and Matthew 11.25: "I thank thee, 0 Father, Lord of heaven and earth, because thou hast hid these things from 
the wise and prudent, and hast revealed them unto babes." 25

Much Iike Jerome, Gregory the Great (Gregory I), advocates the humble simplicity of Christian folly as an alternative to the sophisticated prudence of worldly wisdom. As Barbara Swain points out in her study of fools and folly in the Middle Ages and the Renaissance, Gregory's

- . eloquent indictment of the wisdom of the world denied that right conduct like that described in Solomon's proverbs and the Cato would win man the bliss of eternal life, and he pleaded for an opposite way of life which it was only logical to call folly.26

In leading the "innocent and pure life," however, man paradoxically becomes, as Miss Swain suggests, a "heroic fool" (Swain, p. 36). 27

Gregory further develops his concept of the heroic fool by distinguishing the Christian or "noble" fool from his worldly or "base" counterpart:

It is right for us to know that some within the pale of Holy Church are styled 'fools,' but yet 'noble,' whilst others are 'fools,' and 'base.' For they are called 'fools,' but cannot be 'base,' who contemning the wisdom of the flesh, desire foolishness that shall stand them instead. . who set at naught the foolish wisdom of the world, and covet the wise foolishness of God . . But contrawise they are 'fools' and 'base' men, who while 8 in following themselves ... flee from the wisdom Above. 28

Both Jerome and Gregory, then, in their praise of the Christian fool's humility, meekness, and innocence, manifest a kinship in their views to the concept of wise folly which characterizes the "Tertullian family."

Similar to the type of folly praised by Jerome and Gregory, is Thomas a Kempis' praise of a life dedicated to the imttation of 
Christ. In his influential treatise entitled of the Imitation of Christ, the fifteenth-century monk relates the idea of Christian folly to the concept of contemptus mundi. ${ }^{29}$ Man exhibits the highest kind of wisdom, Kempis writes in the first chapter of his treatise, by "despising . . this world [in order 7 to draw daily nearer and nearer to the kingdom of heaven" (Imitatio, 1.1.4). Like Jerome and Gregory, Kempis instructs man to be humble: "thou mayst not right wisely think thyself learned but oughtest rather to confess thine ignorance and folly" (Imitatio, 1.2.6), for "if thou wilt be exalted in heaven, humble thee here on earth" (Imitatio, 3.56.207). By imitating Christ, he argues, the humble man will "receive in short time more perfectly the true wisdom of God, than another that studieth ten years in schools and lacketh meekness" (Imitatio, 3.43.174)。

Emblematic of the entire Imitatio, the chapter entitled "That we should eschew vain secular learning" indicates how Kempis' view of Christian folly is both similar to, and different from, the kind of Christian folly praised by Tertullian and his more theologically radical disciples. After quoting First Corinthians 4.20 ("For the kingdom of God is not in word, but in power"), Kempis paraphrases Psalm 94.10 ("I am He that teacheth man knowledge"):

When thou hast read and understood many doubts, yet nevertheless it behoveth thee to come to one who is the beginning of all things, that is God himself, and else thy knowledge shall little avail thee.

I am he that teacheth a man wisdom and giveth more understanding to meek persons, than can be given by man's teaching. And he to whom I speak shall soon be made wise and much shall he profit in spirit (Imitatio, 3.43.173-74). 
Kempis' assertion that the "natural wisdom" of "meek persons" exceeds the acquired learning of learned men echoes Matthew 11.25 and parallels the arguments of Jacopone and Bernard that God rejects the learned in favor of the simple-minded as receptacles of His wisdom. Deviating from the idea of Christian folly praised by members of the "Tertullian family," however, Kempis suggests that man achieves the wisdom of folly after he has experienced the folly of wisdom ("when thou hast read and understood many doubts"). In his deviation from the Tertullian school, Kempis may be seen as a transitional figure among the praisers of folly. While in agreement with those advocating Grace alone as sufficient for salvation, Kempis, to an extent less than St. Augustine and Nicholas of Cusa, anticipates the type of Christian folly praised by Erasmus and Rabelais. For these two Renaissance humanists, as we shall see, man chooses the wisdom of Christian folly only after recognizing the limitations of worldly wisdom.

For Kempis, then, man becomes "wise in spirit" by imitating Christ's humility and charity: "not to presume of himself, and always to judge and to think well and blessedly of others, is a sign and a token of great wisdom" (Imitatio, 1.2.6). Kempis' central thesis that man should emulate the life of Christ because His teaching is superior to that of the worldly wise is reflected throughout the Imitatio and informs his statement of Christian folly. 30 Like Gregory's "noble" fool, Kempis' neophyte in the school of true wisdom sacrifices his reason before the omniscience of Christ the teacher, while learning that the way to divine wisdom is through 
the folly of humility. Kempis' importance to the tradition of Christian folly should not be overlooked, Walter Kaiser reminds us, for both "Kempis and Nicholas of Cusa gave the medieval world its final theological apologies for the fool" (Kaiser, p. 9).

\section{II}

Thus far we have noted the general agreement among members of the so-called "Tertullian family" concerning the type of Christian folly which they praised as an alternative to worldly wisdom. We have also seen that some members of the loosely related "Tertullian family," such as Thomas a Kempis, have expressed a type of folly less radical than that expressed by Tertullian or Jacopone. To a lesser extent than his school companion at Deventer, Nicholas of Cusa, Kempis anticipates the concept of wise folly which Kaiser shows is peculiar to the Renaissance. ${ }^{31}$ A fuller understanding of the Renaissance concept of wise folly may be achieved by pointing out how it emerged from the Augustinian concept of "learned" or "knowing ignorance" (docta ignorantia).

Although Augustine's version of Christian folly is similar in many minor respects to the version expressed by the "Tertullian family," the Augustinian concept of Christian folly radically differs from that of the "Tertulilan family" in one major respect. Whereas Tertullian would argue that the fool for Christ must sacrifice his reason to be worthy of receiving divine wisdom, Augustine would maintain that man can be a Christian fool and still exercise his reason 
in pursuit of temporal things (scientia) provided that he perceive that the knowledge of temporal things is only a step on the ladder leading to sapientia or wisdom--"the contemplation of things eternal." 32

Underlying Augustine's idea of Christian folly is his concept of docta ignorantia, a paradoxical phrase which indicates the distinction between human and divine wisdom。 ${ }^{33}$ As expressed in one of his letters, "knowing ignorance Is] an ignorance taught by the spirit of God which comes to the help of our weakness" (Fathers, XVIII, 398). This "knowing ignorance" manifests itself in the believer's ability to comprehend, to some degree, the mysteries of the faith. For example, even though the trinity is "far removed from the hearts of the prideful wise," Augustine writes in a letter entitled "On the Presence of God," it is not removed "from Christian hearts; consequently not from the truly wise" (Fathers, $x x x, 237$ ).

Other statements expressing the Augustinian concept of Christian folly appear in various sermons and commentaries on Pauline texts. For example, the sermon entitled "On the Resurrection of the Body, against the Pagans," develops the Pauline argument that folly is a stepping stone to wisdom (I Cor. 1.18). "If the wisdom of this world is foolishness in the eyes of God," Augustine argues, "then how far from God is the true foolishness of the world?" (Fathers, XXXVIII, 243) Christian folly is distinguished from the "true foolishness of the world," however, because it is a "foolishness . . which has led to God, concerning which the Apostle says: 'since, in God's wisdom, 
the world did not come to know God by "wisdom," it pleased God, by the foolishness of our preaching, to save those who believe'" (Fathers, XXXVIII, 253).

The Augustinian concept of Christian folly becomes more apparent in Augustine's correspondence with his boyhood friend Bishop Evodius. In a letter to Augustine, circa 415, Evodius asks Augustine to comment upon the various meanings of wisdom, such as "God is wisdom, the wise mind is wisdom; and how it is spoken of as light, as the wisdom of Beseleel . . as the wisdom of Solomon or any other, and how they differ from each other" (Fathers, XX, 363). Augustine replies that God has blessed "the clean of heart, for they shall see [Him]," and then comments upon the necessity for the foolishness of preaching:

This foolishness of preaching and 'foolishness of God which is wiser than men' draws many to salvation, and so, not only those who are not yet able to perceive with sure understanding the nature of God which they hold by faith, but also those who do not yet distinguish in their own mind incorporeal substance from the common nature of the body, and do not know how to live, know, and will, are still not deprived of salvation which that foolishness of preaching bestows on the faithful (Fathers, XXX, 53). 34

The words "those who are not yet able to perceive with sure understanding the nature of God wich they hold by faith" epitomize the distinction between Augustine's concept of Christian folly and that of Tertullian and his disciples. The phrases "with sure understanding" and "hold by faith" express the Augustinian dictum that whereas faith is a prerequisite to understanding, "understanding is the reward of faith." 35 summarizing the relationship between 
understanding and faith in Augustinian thought, Gilson argues that, for Augustine,

...we are invited by Revelation itself to believe, that unless we believe we shall not understand; [and] that far from inviting us to do away with reason, the Gospel itself has promised to all those who seek truth in the revealed word the reward of understanding (Gilson, p. 20).

Unlike Tertullian, Gilson continues, Augustine encouraged the "passionate effort to investigate the mysteries of Revelation by the natural light of reason" (Gilson, po18). Whereas Tertullian condemns all wisdom except faith in "the foolishness of God," Augustine rejects only that misuse of wisdom which manifests itself in condemning the cross:

I would say . . . that wisdom is not to be avoided because there is also false wisdom, to which Christ crucified is foolishness, though He is 'the power of God and the wisdom of God' (Fathers, XVIII, 304-5).

Thus, although St. Augustine expresses several common aspects of the idea of Christian folly, such as the contrast between worldly wisdom and divine wisdom, he clearly does not exhibit the extremism of those like Tertullian who demand that man completely humiliate his reason in order to qualify as a receptacle of divine wisdom.

The fifteenth-century treatise-writer Nicholas of Cusa is known not only as St. Augustine's spiritual descendant, but also, along with Thomas à Kempis, as an instrumental figure in laying "the philosophical foundations for the concept of the wisdom of folly" in the Renaissance. ${ }^{36}$ In the Augustinian tradition, Cusa uses the paradoxical concept of docta ignorantia, as F. Edward Cranz notes, to "vanquish the proud spirit of reason" (Cranz, 131). In a passage from 
De docta ignorantia, which first appeared in 1440 , one year after Kempis' Imitatio, 37 Cusa explains that the highest manifestation of "learned ignorance" is its ability to comprehend the fact that God's word is incomprehensible: 38

This knowledge of its incomprehensibility is the most joyful and desirable comprehension, not as it relates to the comprehender, but to the loveliest treasure of his life. For if any man should love anything because it were lovable, he would be glad that in the lovable there should be found infinite and inexpressible causes of love... This is the most joyful comprehension of the incomprehensible and lovable learned ignorance: to know partially and yet to have no perfect knowledge. 39

In agreement with other advocates of Christian folly, Cusa argues that God "cannot be apprehended within the context of this world, for 7 here we are led by reason, opinion, or doctrine from the better known to the less known by symbols; whereas he is grasped only when movement ceases and faith takes its place."40 In the eleventh chapter of of Learned Ignorance, entitled "The Mysteries of Faith," Cusa further develops the idea that only the simple and humble are fit receptacles for God's wisdom by alluding to Matthew 11.25: "The greatest and profoundest mysteries of God, though hidden from the wise, may be revealed to little ones and bumble folk living In the world by their faith in Jesus: for in Jesus are hidden all the treasures of wisdom and knowledge, so that without Him no man can do anything" (Cusa, p. I61)。Cusa's contribution to the tradition, however, lies neither in his similarity to the advocates of Christian folly in general, nor to Augustine, in particular. Among the praisers of Christian folly, Cusa is most important in providing the Renaissance 
with an "oxymoronic concept of the wise fool."4l

In light of Walter Kaiser's full-length treatment of the Erasmian and Rabelaisian concept of wise folly, any attempt here to expand upon what has already been so admirably done would be superfluous. It may be useful, however, to summarize briefly what Kaiser has said about the Renaissance concept of wise folly, particularly since Sterne's Tristram may be seen as a maverick descendant of the Renaissance wise fool. It may also be useful to conclude the second section of this chapter by seeing how Sir Thomas More, whom Erasmus considered the exemplary Christian fool, embodied the oxymoronic concept of wise folly.

While Erasmus' persona, Stultitia, devotes the first part of her oration to ironically praising the "foolish folly" (as distinct from "wise folly") of her many followers--"the number of fools is infinite," she reminds her audience by quoting Solomon--she laces her satire with sympathy for mankind. Her equivocal attitude toward folly is evident in her very appearance. Ridiculing human folly by ironically praising its many forms, Stultitia stands before her audience dressed not in the lofty robes of the academician, but in the simple garb of the fool. "Even when Stultitia turns her invective against her followers," Walter Kaiser reminds us, "we are aware that it is done out of pity for the victims of such fools--and not wholly without pity for the fools themselves" (Kaiser, p.99). Emblematic of her attitude toward human folly is her observation that men listen to "clowns and jesters" (Folly, p. 101), but sleep through sermons, 
because "to live in folly, to err, to be deceived, and to be ignorant -. is . . to be human" (Folly, p. 122).

But if Stultitia ironically praises all kinds of folly, she seriously praises one kind in particular--the wise folly of the fool for Christ. In contrast to the foolish folly of the scholastics, Stultitia holds up as a norm the wise folly of Paul, "who could present faith . . but .. . did not define it doctorally" (Folly, p. 144)。 Significantly, Stultitia cites Paul as the great advocate of wise folly, for, like Stultitia, Paul taught the lessons of wisdom although he publicly claimed to "speak as a fool" (II Cor. II.23). 42 As soon as she quotes from Paul's epistle to the Corinthians, Walter Kaiser observes, her "tone changes once more, [and] a new and higher seriousness enters her jest" (Kaiser, p. 87).

Because she is a wise fool, Stultitia holds up the perfection of St. Paul's Christian folly as a norm to gauge the foolishness of this world's wisdom. The Christian basis of her concept of wise folly is epitomized by her observation that "the whole of the Christian religion seems to have a certain relationship with some kind of folly but fails to agree at all with wisdom" (Folly, p. 169). Some fools, however, never make the distinction between foolish and wise folly and thus fail to achieve the transcendent vision of the Christian fool. One such imperfect fool is Rabelais' Panurge.

Like Stultitia, Walter Kaiser remarks, Panurge is "the fool as court jester, the fool as companion, the fool as goad to the wise and challenge to the virtuous, the fool as critic of the world 
(Kaiser, p. 127). However, "In the last analysis," Kaiser continues, Panurge "is not so perfect a fool as she, for he lacks the ultimate wisdom of folly. . . That final wisdom is .. reserved for someone else. At the end of the book, as at the beginning, it is Pantagruel, not Panurge, who possesses Stultitia's highest wisdom" (Kaiser, p. 127). In Book III of The Histories of Gargantua and Pantagruel, the Rabelaisian idea of Christian folly emerges from the dialectical interaction of the two fools, Panurge and Pantagruel. A "fool may well give lessons to a wise man," the wise fool Pantagruel says to his foolish, but not as wise counterpart, and the entire third Book may well be seen as "a story of l'education du fou. "43

Rather than tell Panurge, Pantagruel attempts to show him that Christian folly is the highest wisdom. At the beginning of Book III, Panurge asks Pantagruel whether or not he should marry. Desiring Panurge to reach his own decision, Pantagruel suggests that Panurge must first know himself and that "all the rest is fortuitous and depends on the disposition of the heavenly fates" (R., 3.10.313).44 Because he does not know himself, however, Panurge seeks the answer to his question from various classical sources of truth, such as Virgilian lots, the divination of his dreams, and a sibyl. The climax of Panurge's quest for truth ${ }^{45}$ comes in his meeting with a theologian, a doctor, and a philosopher, all representing different kinds of human wisdom. The failure of these representatives of human wisdom in providing Panurge with a satisfactory answer is epitomized in the dialogue between Panurge and the philosopher, "Wordspinner." The 
dialogue begins as Pantagruel poses the question of whether Panurge should marry or not.

'Both,' replied Wordspinner.

'What are you saying to me?' asked Panurge.

'What you heard, ' replied Wordspinner.

'What did I hear?' demanded Panurge.

'What I said,' replied Wordspinner ( $R_{0}, 3.35 .384-85$ ).

As indicated by his conversation with "Wordspinner," Panurge does not realize that self-knowledge is a necessary step on the road to wisdom. Walter Kaiser reminds us that Panurge

- - must accept the fact that he does not and cannot know, and leave the rest to God; but God will not assist him until he has achieved the wisdom of knowing that he is a fool. As long as he rests in the doubt of worrying whether or not he will be cuckolded, he is an unfit receptacle for the grace of God. That is what Pantagruel had told him at the outset: that he should make up his mind whether or not he wishes to get married and then follow his will, prepared to leave the question of cuckoldry to God and equally prepared to accept whatever God determines. The problem is, of course, that he cannot make up his mind and cannot be "assured of his will" about getting married until he is able to accept his own ignorance about the future. As long as he tries to determine the future, so long will the future worry him and prevent his will from being free.

Panurge never learns the lesson that the events of the Tiers Livre ought to teach him, however, and his final

appearance, when he confronts the fool Triboullet, is intended to show us that (Kaiser, p. 174).

Dissatisfied with the answers of the wise, Panurge is

rescued from despair by Pantagruel's suggestion that he should "take counsel of some fool" ( $\left.R_{0}, 3.37 .390\right)$. The argument that Pantagruel offers for seeking wisdom from a fool echoes the teaching of the wise fool Stultitia that man must reject this world's wisdom before he can achieve the transcendent wisdom of Christian folly. In order to be wise "in the estimation of the celestial spirits," Pantagruel 
tells Panurge, a "man must forget himself . . rid his senses of all earthly affection... and view everything with unconcern: all of which are commonly supposed to be symptoms of folly" ( $R_{0}, 3.37 .390-91$ ). Unlike the answers given Panurge by the representatives of worldly wisdom at the symposium, the cryptic answer of the fool, Triboullet ("By God, God, mad fool, beware of the monk!") ${ }^{46}$ carries the weight of divine prophecy. As Walter Kaiser points out, Triboullet

. . is a "natural" fool, a witless individual with no capacity for reason... But . . he is capable of being a receptacle for the wisdom of God--a potentiality that Pantagruel made clear when he first suggested him, explaining that a fool could be "not only sage, but [able] to presage Events to come by Divine Inspiration" (Kaiser, pp. $174-75)$.

During his meeting with Panurge, Triboullet reveals his divinely inspired prophetic abilities when, "with a violent wag of [his] head," he denounces Panurge as a "mad fool" and warns him to "beware of the monk" ( $\left.R_{0}, 3.45 .412\right)$. Triboullet calls Panurge a "mad fool" because Panurge pompously "expound $[$ his problem to Triboullet in rhetorical and elegant language" ( $R_{0}, 3.45 .412$ ), thereby indicating his desire "to receive some putative source of wisdom" instead of "being prepared to receive the decree of heaven." 47 Paradoxically, then, the "fool" Triboullet wisely perceives that the source of Panurge's problem during his entire quest for truth is his failure to know himself. Triboullet's warning about the monk is a direct response to Panurge's often-posed question a bout being cuckolded. Significantly, as Pantagruel reminds Panurge 
(R., 3.46.414), it is Triboullet, and not the worldly wise men, who both exhibits the power of divine prophecy and provides Panurge with an answer about the danger posed by the licentious monk.

The contrast between Pantagruel's ability to perceive the wisdom of Triboullet's folly and Panurge's failure to do so is further suggested by the various interpretations which Pantagruel and Panurge assign to Triboullet's violent head-wagging. Whereas Pantagruel maintains that Triboullet's epileptic movement was "caused by the invasion and inspiration of the prophetic spirits which shook it" (R., 3.45 . 412-13), Panurge dismisses it as a sign of Triboullet's unwise folly. "He's a fool all right," Panurge says of Triboullet, "and I am a perfect fool for explaining my thoughts to him" (R., 3.45.412). "To be sure," Kaiser argues, both Panurge and Triboullet "are fools, but they are quite different kinds of fools" (Kaiser, p. 176). Panurge is a fool because, in his frustrated rage with the antics of Triboullet, he refuses to accept Triboullet's judgment that he (Panurge) is a fool. It is worth recalling Kaiser's observation that "God will not assist _Panurge] until he has achieved the wisdom of knowing that he is a fool" (Kaiser, p. 174). Because Panurge rejects Triboullet's judgment that he is a fool, he therefore becomes incapable of accepting the possibility that the power of divine prophecy could reside in a fool.

Unlike Panurge, Pantagruel knows that the wisdom of Christian folly is reserved only for those who can perceive the limitations of what this world calls wisdom. Whereas the depressed Panurge knows no 
more about himself at the end of the Third Book than at the beginning of his quest for truth, Pantagruel's knowledge of the wisdom of folly enables him to become "the exemplar and paragon of perfect jollity" (R., 3.51.426). Because he knows that worldly wisdom is not a substitute for self-knowledge, Pantagruel, and not Panurge, manifests what Walter Kaiser calls "the true happiness.. [017. Christian folly" (Kaiser, p. 181).

Summarizing the similarity between the Rabelaisian and Erasmian versions of Christian folly, Walter Kaiser cogently remarks that - In Rabelais' hands, the Erasmian fool is split up. By means of her irony, Stultitia was able simultaneously to be the foolish and the wise fool; but when, in the drama of Rabelais' narrative, these two contradictory types of fool confront each other, each is personified by a separate character. Foolish and wise folly are dymamically opposed in the dialectic between Panurge and Pantagruel . . . Such a bifurcation does not, however, signify any substantial difference between Erasmus' and Rabelais' concepts of the fool: it is simply the artistic result dictated by two different modes of presentation (Kaiser, pp. 127-28).

The Erasmian and Rabelaisian ideas of wise folly may become more meaningful if they are presented in the light of the words and deeds of Sir Thomas More, who personified for his age the humanistic concept of wise folly.

The relationship of Sir Thomas More to Erasmus' The Praise of Folly is well known. More's family name literally means "fool" in Greek, and, Walter Kaiser reminds us, "it was in More's house that the Moriae encomium was written; it was at his suggestion that it was expanded; and it is to him that it is dedicated" (Kaiser, p. 27). In his dedication to The Praise of Folly, Erasmus explains the nature 
of More's proximity to folly: "your family name of More . . is as close to the Greek word for folly as you are far from the meaning of the word" (Folly, p.99).

The irony of Erasmus' dedication is that while More was far from being a foolish or worldly fool, he embodied the wise type of Christian folly praised by his fellow humanist, Erasmus. Indeed, More, who kept a fool as part of his household, seems to have exemplified for Erasmus the perfect combination of wisdom and folly fitting a Renaissance man of this world who did not neglect his duty to the next. In one of his letters (Epist. 447, to Ulrich von Hulten, 1519), Erasmus points out that More was "a second Democritus, always full of gaiety, excelling in witty repartees, and conversing with ease with men in every rank of life. 148 More's public speeches, as recorded by his biographer and son-in-law, William Roper, bear out his friend's observation and secure More's reputation as a wise jester in public office. For example, in a speech before Henry VIII soon after his appointment as speaker of Commons, the learned More hoped that his "simpleness and Folly" would not "hinder or impair" the "prudent devises and affaires" of Commons. 49

More's favor with Henry, who employed him as an adviser and speech-maker because of his "wisdome and learninge" (Roper's Life, p. 22), waned as soon as More staunchly opposed the King's declaration of supremacy as the head of the Church of England. His opposition to Henry's means of validating his marriage to Anne Boleyn first cost More the loss of public office and royal favor, and soon 
led to his imprisonment and execution. More's actions and statements during this period of his life merit attention because they dramatically illustrate his stature as a fool for Christ.

Typical of More's reaction to his loss of political and social prestige was his proclamation to his family of "what an happie and blessed thinge it was, for the love of god, to suffer losse of goods, imprisonment, losse of lands and life also" (Roper's Life, p. 56). 50 To More, man's religious duty and the imminent possibility of martyrdom were not matters for jest. His life-long dedication to the teachings of the Church and his unpretentious personal faith ${ }^{51}$ exemplify the highest standards of Christian folly.

During one of his wife's visits to the Tower of London, his place of imprisonment, More demonstrated the high seriousness of his religious conviction. Upon seeing a priest and three monks marching to their execution for opposing Henry's Act of Supremacy, More envied their cheerfulness in "goinge to their deathes as bridegroomes to their Mariage" (Roper's Life, p.80). More's envy of the condemned men is characteristic of the spirit of Christian folly. Typical of the cautiousness of worldly prudence is his wife's condemnation of his course of action:

I mervaile that you, that have bine alwaies hitherto taken for so wise a man, whill nowe so play the foole to lye heare in this close, filthy prison... when you might be abroade at youre libertye (Roper's Life, p. 82).

In the eyes of his wife, as in the eyes of the world, More was a fool because he refused to sacrifice his personal standards and his 
faith for the rewards of this world. If More is judged not by worldly standards, but by the Pauline-Erasmian paradox that worldly wisdom is folly, and Christian folly is wisdom, his apparently absurd actions form the basis of a transcendent faith in God's grace. Right up to the last few moments of his life, More was the perfect wise fool. After the death sentence was passed against him, he prayed for his judges and reminded them of Saint Paul who "consented to the death of St. Stephen, and kepte their clothes [i。e, the clothes of St. Stephen's attackers7 that stoned him to death" (Roper's Life, p.96). Thereafter, More fervently wished to die on the Eve of St. Thomas; expressed sincere gratitude to the King for ridding him so soon "of the miseries of this wretched woorld" (Roper's Life, p. 100); and sent his executioner "one Angell of gold" (Roper's Life, p。 102). All of More's actions set the stage for his final jest in which the comic and the serious are perilously balanced in true Erasmian fashion. Noting that the scaffold at the place of execution was so weak that it was about to fall, More observed: "'I pray you, master Leiuetenaunte, see me salf vppe, and for my cominge downe let me shifte for my selfi" (Roper's Life, p. 103). A fool who goaded vain authority on the one hand, More was simultaneously a profound Christian on the other, for he desired that the crowd pray for him and bear witness that he was dying "in and for the faith of the holy catholik churche" (Roper's Life, p. 103). Only after his affirmation of martyrdom did More "put his beard out of the way when he laid his head on the block, remarking to the headsman, that it at least had 
not committed treason." 52

More's jests do not negate the horror of his execution, but they do make bearable the absurdity of its occurrence. By the same token, his jests do not negate his martyrdom, for More provided the Renaissance with the living example of Christian folly. In his life and death, then, Sir Thomas More demonstrated the Pauline doctrine that the folly of Christianity is the highest wisdom. In addition, More showed that Christian folly was more than an abstract theological concept, for he made it a concrete way of life in this world. The manifestation of the tradition in this world is the legacy which More and the Renaissance humanists provided to posterity, and it is to the way in which some late seventeenth-and early eighteenth-century writers treated this legacy that we turn next.

\section{III}

In Book VIII of Paradise Lost, the angel Raphael expresses a Miltonic version of the Augustinian concept of "learned ignorance" when he instructs Adam to be "lowlie wise" and to "think onely what concernes [him7 and [his 7 being" (VIII, 173-74). 53 Echoing the words of Paul in Romans 1.22 ("Professing themselves to be wise, they became fools"), Milton's Raphael warns Adam in Book VII that the abuse of carnal knowledge "soon turns/Wisdom to Folly" (VII, 129-30). One of the strongest arguments for embracing one of the forms of Christian folly, such as "learned ignorance" or "lowlie wisdom," is precisely Milton's reminder that the pursuit of forbidden knowledge often leads 
to folly in the eyes of God. Seventeenth-century Anglican divines, such as Henry Hammond ${ }^{54}$ and Robert South, ${ }^{55}$ and the French moralist, Nicolas Malebranche, 56 also reminded man that while abuses in carnal wisdom lead to folly in the eyes of God, Christian folly is the highest wisdom. A brief examination of the expressions of the concept of Christian folly appearing in the works of these late seventeenthcentury writers will provide a clearer understanding of Sterne's use of Christian folly in the eighteenth century.

The form of Christian folly which appears in Milton's Paradise Lost--the concept of "lowlie wisdom"--emerges from the contrast between the two opposing conceptions of wisdom held by Satan and by Adam, at the end of the poem. Even after the defeat of his rebellious forces at the hands of God's angels, Satan feels that wisdom lies in disobeying God by attempting to subvert His plan for mankind. As the angel Gabriel scornfully warns Satan in Book IV, however, Satan's "wisdom" in leaving Hell and attempting to subvert the divine plan is sheer folly:

So judge thou still, presumptuous, till the wrath, Which thou incurr'st by flying, meet thy flight

Sevenfold, and scourge that wisdom back to Hell (IV, 912-14).

For Satan, then, wisdom lies in the exercise of revenge and force. On the other hand, Adam sees, at the end of the poem, that wisdom is to "love with feare the onely God" (XII, 561). By grasping the paradox of Christian folly--that God, "by things deem'd weak/ Subvert S worldly strong, and worldly wise/By simply meek" (XII, 567-69), 57 Adam attains nothing less than "the summe of wisdome" (XII, 575-76)。 
In Paradise Lost, the idea of Christian folly, which appears as Milton's concept of "lowlie wisdom," is a further example of the continuation of the tradition of Christian folly in imaginative literature. In general, however, the most common expressions of the idea of Christian folly in the seventeenth century appeared in the Biblical commentaries and sermons upon Pauline texts by Anglican divines. The commentaries of Henry Hammond, Daniel Whitby, 58 and John Locke $e^{59}$ are relevant to this discussion of Christian folly because they contain some of the terms which preachers such as Robert South and Sterne himself use in translating the idea of Christian folly out of the realm of Scriptural exegesis and into the sphere of seventeenth and eighteenth-century life. In his commentary upon Paul's Epistles, Hammond, chaplain to King Charles I, glosses the "wise" men and scribes mentioned in I Cor. 1.20 as the "philosophers and learned or searching men... whose7 deep wisdom of the world ... is absolute folly" in comparison with "the doctrine of Christ." 60 To John Locke, the "wisdom of the world" which Paul denounces in First Corinthians is "the knowledge, arts, and sciences attainable by man's natural parts and faculties; such as man's wit could find out, cultivate and improve, 61 and to Hammond, the wisdom of the world which Paul attacks in I Cor. 1.19 is "an habit of science or prudence" (Hammond, p. 512)。 As Daniel Whitby sums up in his "Preface" to A Paraphrase and Commentary upon St. Paul's First Eplstle to the Corinthlans, "the Apostle spends the latter part of the first chapter [i.e., of First Corinthians7, from verse twenty to the end, in showing 
the vanity of the wisdom which the philosophers pretended to, in comparison to the wisdom discovered by the Gospel, preached by the Apostles" (p. 101)。

In a sermon preached at Westminister Abbey on April 30, 1676, Robert South presents the idea of Christian folly in terms of the contrast between the worldly prudence of "policy . . Which7 consists in a certain dexterity or art of managing business for a man's secular advantage" 62 on the one hand, and the divine "folly of being sincere, and without guile; without traps and snares in our converse" (South, p. 371), on the other. South points out that "the wisdom of the world. . Is taken in Scripture, in a double sense . . that sort of wisdom, that consists in speculation; called Philosophy .. . [and] such a wisdom as lies in practice, and goes commonly by the name of policy" (South, p. 335). To South, it is this latter kind of wisdom which Paul "intended in the text; namely, that practical cunning that shows itself in political matters, and has in it the mystery of a trade or craft" (South, p. 336).63

The first part of South's sermon consists of a discussion of the four "principles" by which "policy or wisdom governs its actions" (South, p. 336). The first is dissimulation; the second, the notion "that conscience, and religion ought to lay no restraint upon men at all, when it lies opposite to the prosecution of their interest" (South, p. 336); the third, "that a man ought to make himself, and not the public, the chief, if not the sole end of all his actions" (South, p. 346); and the fourth, "that in showing kindness... no 
respect at all is to be had to friendship.. sense of honor; but that such favors are to be done only to the rich or potent, from whom a man may receive a further advantage" (South, p. 346).

In the second part of his sermon, South demonstrates "the folly and absurdity" of the four principles by which policy governs its actions "in relation to God" (South, p. 352). From the perspective of God, man is foolish for following these principles, for, in the first place, he "pitch_es] upon such an end which7 is unsuitable to his condition" and second, he "pitch_es] upon means unsuitable to the compassing of his end" (South, p. 352). "There is folly enough in either of these," South continues, "and my business shall be to show, that such as act by the fore-mentioned rules of worldly-wisdom, are eminently foolish upon both accounts" (South, p. 352). In opposition to these principles for success in the world, which the world applauds as wisdom, South exhorts his audience to embrace his version of the idea of Christian folly:

Let us not be ashamed of the folly of being sincere, and without guile; without traps and snares in our converse; of being fearful to build our estates upon the ruin of our consciences ... I say, let us not blush to be found guilty of all these follies, (as some account them) rather than be expert in that kind of wisdom, that God himself ... has pronounced to be earthly, sensual, devilish; and of the wretched absurdity of which, all histories . . have given us such... convincing examples (South, p. 371).

In the seventeenth and eighteenth centuries, the idea of Christian folly also took the form of a reaction against neo-stoicism. Rae Blanchard reminds us that "the Stolc exaltation of reason had been revived at the end of the sixteenth century and the beginning of the 
seventeenth . . and was still a potent force at the time Steele wrote." 64 According to the neo-stoics, the wise man combats his passions by means of his reason. In the words of one propagandist for stoicism:

Reason is then Man's only benefit; he must use it to climbe heaven, he must consult it to govern his Life, and if he do but hearken unto her, he shall be vertuous, and tame the most insolent of his Passions. 65

For the advocates of such hyper-rationalism, the doctrines of Christianity were all but worthless. As one writer sums up, . . neo-stoicism $[$ is 7 . . made for rational people, for intellectuals who rationalize everything; their faith and the deeds which it prescribes for them, but who will never have the folly of the cross. Neo-stoicism is finally a Christian rationalism, in which Christianity does not always appear as essential, but rather as superadded. 66

The reaction of Christian apologists to the dictums of neostoicism may be viewed, in part, as an attempt to eulogize those who possessed and rejoiced in "the folly of the cross." In The Christian Hero (1701), for example, Richard Steele describes the primitive Christians as "the most truly Gallant and Heroick [men] that ever appear'd to mankind."67 Another defense of Christianity, Nicolas Malebranche's Treatise concerning the Search after Truth, rejects the wisdom of the stoic's virtue in favor of the folly of the early Christians' faith. In the chapter entitled "Of the Imagination of Seneca," Malebranche states:

The Vertue of the Stoicks could never render them impregnable; since 'tis not inconsistent with true Vertue for a Man to be Miserable, and pitiable at the time of his Suffering some evil: St. Paul and the Primitive Christians, had doubtless more Vertue than Cato and all the Stoicks: and 
yet they confess'd they were miserable through the Pains they endur'd; though they were Happy through the Prospect of an Eternal Retribution . . . Alas, poor Cato! thou fanciest thy Vertue raises thee above all things: whereas thy Wisdom is Folly, and thy Magnanimity abominable before God; whatever the Wise-Men of the World may think of it (Malebranche, p. 94).

Similar to the Patristic writers, medieval theologians, and Renaissance humanists who preceded them, then, some of the late seventeenth and early eighteenth-century apologists for orthodox Christianity utilized the idea of Christian folly to combat the particular evils of their age. Tertullian presented Christian folly in the form of intellectual humility vs. gnosticism; Cusa, in the form of "learned ignorance" vs. scholasticism; Milton, in the form of "lowlie wisdom" vs. forbidden knowledge; South, in the form of sincerity and honesty vs. opportunism and "practical cunning"; and Malebranche, in the form of piety and faith in providence vs. stoical morality. Regardless of its various forms, the idea of Christian folly is based upon the Pauline paradox that the foolishness of God is wiser than the wisdom of this world. Both as a preacher and a novelist, Laurence Sterne incorporated some of these traditional forms of Christian folly into a norm against which he tested the foolishness of this world. 


\section{Notes}

1. The Sermons of Mr. Yorick, 2 vols., in The Writings of Laurence Sterne, The Shakespeare Head Press ed。 (Oxford and New York, 1927), Vol. II, p. 56. Subsequent references are to this edition and will be cited hereafter as Sermons.

2. In Praisers of Folly (Cambridge, Mass., 1963), Walter Kaiser points out that "all through the Middle Ages the tradition of the Fool in Christ, whether articulated precisely as such or not, was preserved by such figures as Gregory the Great, Scotus Erigena, Francis of Assisi, Jacopone da Todi, and Raimond Lull" (pp.8-9).

3. For a discussion of the distinction between the "Tertullian family" and the "Augustine family" of Christian thought, see Etienne Gilson, Reason and Revelation in the Middle Ages (New York, 1938), pp. 8-33.

4. Thomas a Kempis, The Imitation of Christ, trans Richard Whitford, ed. Edward J.Klein (New York and London, 1941), Book I, chap. I, p. 4. Subsequent references are to this edition and will be noted in the text as Imitatio.

5. St. Augustine, "Letter No. 120," trans. in The Fathers of the Church, ed。Roy Joseph Deferrari (Washington, D. $\bar{C}$, , 1965), vol. XVIII, p. 304. The title The Fathers of the Church will hereafter appear as Fathers.

6. Kaiser, Praisers of Folly, p. 38.

7. Quoted by Kaiser, Praisers of Folly, p. 88.

8. William Wycherley, Works, ed. Montague Summers (Soho, 1924), vol. III, p. 25.

9. Erasmus, The Praise of Folly, trans. John P. Dolan in The Essential Erasmus (New York, 1964), pp. 162-63. Subsequent references are to this edition and will be cited hereafter as Folly.

10. In The Renaissance Idea of Wisdom (Cambridge, Mass., 1958), Eugene F。Rice, Jr, observes that "since Paul named Christ 'the power of God and the wisdom of God' II Cor. 1.23-24 7 ... and Augustine elaborated this suggestion into coherent doctrine in the De Trinitate, this identification had been a Christian commonplace" (p.2I)。 
11. Earle Ellis, Paul's Use of the Old Testament (Edinburgh, 1957), p. 92.

12. For a discussion of those who had "absolute conviction in the self-sufficiency of Christian Revelation," see Gilson, pp. 8-14.

13. Francois Amiot, The Key Concepts of St. Paul, trans. John Dingle (New York, 1962), p. 129.

14. Tertullian, The Body of Christ, trans. In The Ante-Nicene Fathers (Buffalo, N.Y., 1885), vol. III, p. $439^{\circ}$

15. In his Essays on Primitivism and Related Ideas in the Middle Ages (Baltimore, 1948), George Boas points out that "it may very well be that this famous Father maintained simply that man could not completely humiliate himself before God, so long as he retained his reasoning powers. The belief in the absurd is a belief in the Incarnation and Resurrection, and the words ... 'Certum est quia impossibile est,' and 'Prorsus credibile est quia ineptum est,' may be taken as a sacrifice of human reason analogous to the sacrifices demanded by the vows of chastity and obedience" (p. 121).

16. James M. Edie, "Faith as Existential Choice," in Christianity and Existentialism, ed.William Earle et al (Evanston, Ill., 1963), p. 29.

17. Tertullian, The Ante-Nicene Fathers, III, 525.

18. Ibid.

19. Tbid., p. 526.

20. Ibid., p. 440.

21. Quoted by Gilson, p. 8. Cf. Tertullian, On Prescription Against Heretics, Chapter VII: "What indeed has Athens to do with Jerusalem? What concord is there between the Academy and the Church? what between heretic and Christians?" (quoted by Gilson, p. 9)

22. Gilson, p。8.

23. Jacopone da Todi, "How It Is The Highest Wisdom To Be Reputed Mad For The Love Of Christ," trans. Mrs. Theodore Beck, in Evelyn Underhill, Jacopone da Todi: \& Spiritual Biography (London, 1919), p. 283.

24. Saint Jerome, B. Pauli ad Corinthios prima, Patrologiae cursus vol. XXX, col. T26: 
Illic proprie mundi increpat sapientes, quos humana sapientia non permittebat entire divina, Aliter: Si quis ad reddendam vicem injuriae, si eadem fecerit, iputet se esse sapientem, stultus fiat. In hoc enim saecula stultus est, qui evangelica voluerit implere praecepta: Qui enim percutienti aleram praebat maxillam: voluntate stultus est, non natura.

Nihil stultius est, quam ut velit se, qui non potest, vindicare, et Deo suam non reservat injurium. Et ita de contimelia vindictum apud Deum perdet, et de patientia mercedem.

I am indebted to Professor Joseph Brunet, of The University of Florida, for translating Jerome's commentary on I Cor. 3.18-19.

25. Bibliorum Sacrorum, Iuxta Vulgatum Clementinam. Nova Editio (The Vatican, 1959), po 1070.

26. Barbara Swain, Fools and Folly During the Middle Ages and the Renaissance (New York, 1932), p. 36.

27. Miss Swain cites the following passage from Gregory's Moralium libri sive exposito in librum B. Job (PL, LXXV, col. 947), in which he describes the "innocent and pure life":

The wisdom of this world is, to conceal the truth of one's heart by trickery, to veil one's meaning in words, to make those things which are false appear to be true, to present the truth as falsehood ... But on the other hand the wisdom of the just is, to make no pretences for a show, to make plain one's meaning by one's words, to pursue those things which are true, to shun the false, to do good deeds gladly, to bear evil more willingly than to do it . . . . But this simplicity of the just is laughed to scorn, for worldly wise men believe the virtue of purity to be foolish. Indeed all things that are done innocently seem to them undoubtedly foolish (trans. and quoted by Swain, pp. 198-99)。

28. Gregory the Great, PL, LXXVI, col. 161-62, trans and quoted by Swain, pp.199-200.

29. For a study of the concept of "the contempt of the world" and its relevance to fourteenth-century English literature, see Donald R. Howard, "The Contempt of the World: A Study in the Ideology of Latin Christendom with Emphasis on Fourteenth Century English Literature," unpubl.dissertation, University of Florida, 1954. 
30. In Chapter XLIII, for example, Kempis becomes a mask for Christ: "I teach without sound of words, without diversity of opinions, without desire of honour, and without strife and arguments. I am he that teacheth all the people to despise earthly things, to loathe things that be present [and7 io seek and to savour eternal things" (Imitatio, 3.43.175).

31. For the influence of Kempis and Cusa on Erasmus, see Kaiser, pp. 9-10.

32. In his article, "Saint Augustine and Nicholas of Cusa in the Tradition of Western Christian Thought, "Speculum, XXVIII (1953), 297-316, F. Edward Cranz points out that "Augustine begins his discussion of faith and wisdom by making a general distinction between two types of knowledge. There are two offices of the mind, the one higher and the one lower, and there are two corresponding types of knowledge. In the first case, there is wisdom (sapientia), devoted to the contemplation of things eternal; in the second case, there is science (scientia), devoted to action in things temporal" (306).

In De Trinitate (Bk。13, chap. 19, para。24), St. Augustine maintains that Christ "places within us the faith of things temporal; He exhibits to us the truth of things eternal. We move through Him to Him. We move through science to wisdom" (quoted by Cranz, 306-307).

33. For a discussion of Augustine's concept of wisdom, see Rice, The Renaissance Idea of Wisdom, pp. 11-14.

34. Cf. St. Augustine, The Divination of Demons: "In truth, the Christians' very foolishness of ignorance. . to the humble and the holy and to those diligently devoted to it appears the lofty and the only true wisdom" (Fathers, XXVII, 439).

35. Gilson, p. 19.

36. Kaiser, p. 9.

37. Ibid.

38. For Cusa's identification of divine wisdom with the "incomprehensible word of God," see Eugene F. Rice, Jr., "Nicholas of Cusa's Idea of Wisdom," Traditio, XIII (1957), 345-68.

39. Quoted by Rice, "Nicholas of Cusa's Idea of Wisdom," 363. Cf. Cusa's "Sermon of 1454" where, after quoting Rom.1.20 ("For the invisible things of him from the creation of the world are clearly seen, being understood by the things that are made, even his eternal power and Godhead; so that they are without excuse"), 
Cusa defines "knowing ignorance" as "the sight of invisible things" (quoted by Cranz, "Saint Augustine and Nicholas of Cusa," 312).

40. Nicholas Cusanus, Of Learned Ignorance, trans. Germain Heron (New Haven, Conn., 1954), p. 161.

4l. Kaiser, p. 9.

42. Cf. I Cor. 4.10: "We [apostles] are fools for Christ's sake."

43. Kaiser, p. 127 .

44. Rabelais, The Histories of Gargantua and Pantagruel, trans.

J. M. Cohen (Baltimore, 1955), Book III, chapter 10, p. 313.

Subsequent references are to this edition and will be noted in the text.

45. As Walter Kaiser points out, "the subject of the Tiers Livre is truth and not, as has so generally been said, marriage" (p. 125).

46. R., 3.45.412.

47. Kaiser, p. 175.

48. Quoted in The Dictionary of National Biography, ed. Sirs Leslie Stephen and Sidney Lee (London, 1917), vol. XIII, p. 886.

49. William Roper, Esq., The Life of Sir Thomas Moore, Knight, ed. Elsie Vaughan Hitchcock (London, 1935), p. 13. All subsequent references are to this edition and will be noted as Roper's Life.

50. More may possibly have been thinking of Philippians 3.8, where Paul states: "I count all things but loss for the excellency of Christ Jesus my Lord; for whom I have suffered the loss of all things, and do count them but dung, that I may win Christ." In his sermon "Our Conversation in Heaven," based on Phil. 3.20, Sterne exhorts his congregation to imitate the Apostle Paul's wise and exemplary Iife.

51. The day before his execution More sent his wife a letter together with his hair-shirt, which he always wore, because he was "not willinge to haue it seene" (Roper's Life, p.99).

52. Quoted in The Spectator, No. 349, ed. George Aitken (London, 1898), vol. V, p. 155 n.l.

53. John Milton, Paradise Lost, in The Student's Milton, ed. Frank Allen Patterson (New York, 1930), Book VIII, Iines 173-74. Subsequent references are to this edition and will be noted in the text. 
54. In reply to Boswell's question concerning which Biblical commentators he should consult, Johnson replied: "I would recommend Lowth and Patrick on the Old Testament and Hammond on the New" (James Boswell, Life of Johnson, ed. L. F. Powell [Oxford, 19347, vol. III, p. 58). Hammond's A Paraphrase, and Annōtations Upoñ All the Books of the New Testament, first published in 1654, had gone through its seventh edition in 1702 .

55. Robert South was installed canon of Christ Church in 1670 and was known for his use of humor in the pulpit and for his "direct... dealing with the vices of the age" (DNB, XVIII, 684-85)。

56. Malebranche's De la Recherche de la Verite first appears in 1674 and passed through six editions during the author's lifetime. It was first translated into English by To Taylor (Oxford, 1694) as Father Malebranche's Treatise Concerning the Search after Truth.

57. Cf. I Cor. 1.27: "For God hath chosen the foolish things of the world to confound the wise; and God hath chosen the weak things of the world to confound the things which are mighty."

58. Daniel Whitby's A Paraphrase and Commentary upon all the Epistles of the New Testament (London, 1700) went through eight editions in the eighteenth century.

59. Sterne's general indebtedness to the "sagacious" Locke whom he praises in Tristram Shandy is well known. Lansing van der Heyden Hammond cites Sterne's particular indebtedness to Locke's theological works in Laurence Sterne's 'Sermons of Mr. Yorick' (New Haven, 1948), pp. $138-4 \overline{1}$ 。

60. Henry Hammond, A Paraphrase and Annotations Upon all the Books of the New Testament (London, 1659), p. 511. All subsequent references are to this edition and will be cited in the text by the author's name. Cf. Whitby's paraphrase of I Cor. 1.20: "What hath been done by the wisdom of the philosopher, or by the Jewish doctor, or by the searcher into Nature's secrets, to bring men to the true knowledge of God, and of his will? Hath not God discovered their wisdom to be but folly, in comparison of this way which he hath chosen to bring men to the knowledge of himself?" (p. 113)

61. John Locke, A Paraphrase and Notes on St. Paul's First Epistle to the Corinthians, in The Works of John Locke (London, 1823), vol. VIII, p. 86.

62. Robert South, Twelve Sermons Preached upon Several Occasions (London, 1715), vol. I, p. 335. All references are to this edition and will be cited in the text by the author's name. 
63. In his sermon on "The Advantages of Christianity to the World," Sterne expresses the falseness of worldly wisdom in terms similar to South's: "The politicians of this world . . admit of no other claims of wisdom, but the knowledge of men and business . . . the little men of this world . . . thinks the main point of wisdom is to take care of himself 。 . to make use of opportunity whilst he has it" (Sermons, II, 54-5).

64. Rae Blanchard, ed., "Introduction" to Richard Steele's The Christian Hero (London, 1932), po xvii.

65. Le Grand, Man Without Passion or the Wise Stoick (trans.

G. Ro, 1675), p. 27, quoted by Blanchard, "Introduction," p. xviii.

66. Translated from Leontine Zanta's La Renaissance du Stoicisme au XVI Siecle (Paris, 1914): "En résumé, le néo-stoicisme reste tout proche d'un christianisme moyen, fait pour des gens raisonnables, pour des intellectuels qui raisonnent tout, leur foi et les acts qu'elle leur dicte, mais qui n'auront jamais le folie de la croix. Le né-stoicisme est en définitive un rationalisme chrétien, dans lequel le christianisme n'apparait pas toujours comme essentiel, mais plutot comme surajouté" (p. 337).

67. Richard Steele, The Christian Hero, p. 15. 
Two: The Folly of Wisdom

In Tristram Shandy, Sterne presents the idea of Christian folly in terms of two general contrasts between foolish wisdom and wise folly. The first contrast is between the folly of the novel's worldly wise pedants, represented by Walter Shandy, and the wisdom of the novel's fools, represented by Tristram the narrator, Toby, Trim, and Parson Yorick. The second basic contrast between wisdom and folly which Sterne presents is between the wisdom of Parson Yorick's view of Death and the folly of Tristram's. Whereas Yorick views Death from the perspective of the Christian fool--as the beginning of life, Tristram foolishly fails to achieve the wisdom of folly as a character in attempting to outrun Death in Volume VII even though he exposes the folly of worldly wisdom as a narrator. Before attempting to demonstrate how Sterne projects the idea of Christian folly into the sphere of the Shandean universe, it may be helpful to examine the confusing relationship between Sterne's two personae, Tristram and Parson Yorick. This relationship, I hope to show, illuminates the concept of Christian folly which appears throughout Sterne's work。

Since the publication of Tristram Shandy, there has been a general tendency to associate Sterne with the "heteroclite" (IS, $1.11 .25)^{2}$ Parson of Shandy Hall. ${ }^{3}$ Sterne's biographer, Wilbur Cross, 
contends that Steme's "more ideal self . obears the name of Parson Yorick:"4 while James Work agrees by viewing Yorick as "a sublimated, idealized Sterne" (TS, "Introduction," p. Iviii)。 In an article on "The Laughter of Laurence Sterne," Norman N. Holland suggests that "parson and jester are one. . [ for 7 behind the face of piety, the skull of Yorick laughs." 5 As Henri Fluchere has recently summed up, however, "the character of Yorick tends to be neglected. He is often merely identified with Laurence Sterne the parson, without any real examination into the validity or consequences of such an identification."6 Fluchere's observation that Yorick functions as a court jester in "castigating the proud . . on the dim outskirts of Shandy Hall" (Fluchere, p. 444) indicates, I think, a way of grasping how Sterne exposes the foolishness of worldly wisdom in order to present the wisdom of Christian folly.

Sharing Yorick's function in Tristram Shandy as a kind of court jester is the narrator, Tristram, ${ }^{7}$ who Iikewise satirizes man's pride in the "weakness and imbecility of human reason" (TS, 8.4.543). By exposing the proud spirit of human reason, both Tristram and Yorick develop Sterne"s "plan" in Tristram Shandy, which he said was to satirize not only "the weak part of the Sciences, in which the true point of Ridicule lies--but every Thing else, which I find laugh-atable in my way--" (Letters, No。36, p。74). Unlike Tristram, however, Yorick combines the court jester's satirical function with the Christian fool's dedication to the humility and wisdom of Christ. The relationship between Tristram and Yorick is reminiscent of the 
relationship between Rabelais' Panurge and Pantagruel。 Like Panurge, Tristram fails to become a Christian fool because he is, paradoxically, not "foolish" enough. Even though Yorick's perfect folly earns Tristram's "esteem," It also earns his "blame" (IS, 4.27.324), thus indicating his failure, like that of Panurge, to achieve the final vision of Christian folly. The relationship between Tristram and Yorick becomes less complex if both personae are seen as dramatic representations of complementary aspects of Sterne's "foolish" nature. 10 If Cross' contention that Sterne's "more ideal self. . bears the name of Parson Yorick" is correct, we can, on the basis of Tristram's actions in the novel, view him as representing a more prudent and discrete Sterne. ${ }^{11}$ Although he personally condemned the "understrapping Virtue of Prudence" (Letters, No.38A p.76), Sterne was both well aware and wary of the world's treatment of its fools 12 In Tristram's eyes, Yorick's humility and his imprudent refusal to abandon his "open war" against the affectation of "gravity" (TS, 1.12.26) inform him with an "heroic cast" (TS, 4.27.324) which reflects Sterne's praise of what the world calls "folly。" Wilbur Cross reminds us that "prudence, caution, discretion, the virtues that smooth one's way through life, were ever classed by [Sterne] among the evil propensities of human nature" (Iife, p. 64). By examining certain biographical evidence which shows Sterne's impatience with prudence, we may more clearly view Parson Yorick as an idealized Sterne. In the summer of 1759 , a few months before the publication of the first installment of Tristram Shandy, Sterne replied to a 
friend who had advised him to exercise more prudence as a clergyman:

Mr. Fothergil, whom I regard in the Class I do you, as My best of Criticks \& will wishers--preaches daily to Me Upon your Text--"get Your Preferment first Lory! he says-\& then Write \& Welcome" But suppose preferment is long acoming (\& for aught I know I may not be preferr'd till the Resurrection of the Just) and am all that time in labour- how must I bear my Pains? (Letters, No. 38A, p.76)

Sterne's condemnation of the "understrapping Virtue of Prudence," expressed in the same letter as his "promise to be Cautious" (Letters, No. 38A, p。76), provides a larger context for understanding the respective roles of Yorick and Tristram in Tristram Shandy. In his fearless castigation of the affectation of "gravity" (TS, 1.11.26), Yorick becomes an idealized Sterne who would never admit, as did Sterne himself, under the pressure of public criticism, to having "Burn'd More wit, then [sic7 I have publish'd" (Letters, No。38A, p. 77)。 In his wavering between "esteem" and "blame" (TS, 4.27.324) for Yorick's indiscretion, then, Tristram may be seen as representing Sterne's more cautious self in Tristram Shandy, for he is more aware than Yorlck of the penalties this world exacts upon its fools.

A further indication of Yorick's role as an idealized Sterne is revealed in a letter Sterne wrote to Elizabeth Montagu, shortly before his death in March, 1768. In a likely attempt to remind his wife's cousin of Yorick's jest in the face of death (TS, 1.12.3I), Sterne expressed a desire to die laughing: mon nom dans le liste de et quand Je serai mort, on mettra
plaisantant (Letters, No. 234, p. 416). 
As I hope to show later on in this study, Sterne idealizes Yorick's "jest in death" at the beginning of the novel in order to illustrate a kind of folly which becomes increasingly more wise in Christ as the novel unfolds.

I

Like Erasmus' Stultitia, Sterne's Tristram shows that all men are fools, but that the folly of some fools is wiser than that of others. Tristram's ability to distinguish between kinds of folly is, as we shall see, indicative of his own wisdom. In Tristram Shandy, Sterne's narrator, Tristram, participates in the Erasmian tradition of imparting wisdom while speaking as a fool. Sterne's employment of a "foolish" narrator indicates that the novelist heeded Stultitia's observation that men who are bored at sermons are responsive to fools. ${ }^{13}$ By employing a foolish narrator in Tristram Shandy, Sterne not only assured himself of a more captive audience, but a larger one as well. On one occasion, Sterne recorded that his entire congregation consisted of "one Bellows Blower, three singing men, one Vicar, and one Residentiary."14 Samuel Richardson was hardly exaggerating when he remarked to the Bishop of Sodor and Man that Sterne "passed unnoticed by the world till he put on a fool's coat, and since that everybody admires him!"15

In Tristram Shandy, Sterne's Tristram reveals his "fool's coat" whenever he claims to be a fool. Tristram's claim at the 
beginning of his story that he is not "a wise man" (IS, 1.8.14) echoes

Stultitia's remark at the beginning of her oration, that her outward appearance reveals she is not "Minerva, or Wisdom" (Folly, p. 103)。 Like Stultitia, moreover, Tristram's claim of folly is ironic, for the folly which both of these fools appropriate to themselves paradoxically leads to wisdom. Unlike Stultitia, however, who states that her outward appearance "tell $\sqrt{\mathrm{s}}$ well enough" who she is, ${ }^{16}$ Tristram begs the reader, at the beginning of his story, not to accept his outward appearance at face value:

- . If I should seem now and then to trifle upon the road, - or should sometimes put on a fool's cap with a bell to it, for a moment or two as we pass along, --don't fly off, --but rather courteously give me credit for a little more wisdom than appears on my outside (TS, 1.6.11).

At the end of the story of his life and opinions, Tristram reminds the reader that a book must "keep up that just balance betwixt wisdom and folly" if it is to "hold together a single year" (TS, 9.12.614)。

Tristram's praise of Yorick's wise folly demonstrates such a "just balancell insofar as Tristram, a foolish narrator, is wise enough to praise the wisdom exhibited by Parson Yorick.

Tristram begins his praise of Yorick's wise folly early in Volume I when he eulogizes the Parson of Shandy Hall as his "Hero" (TS, 1.12.28). The remainder of the novel indicates that the phrase "my Hero" is more than a stock narrative formula, for it accurately describes Tristram's esteem for Yorick's courage in refusing to abandon the virtues of humility and righteous indignation in the name of prudence and discretion. Observing that Yorick, unlike his famous 
Shakespearean ancestor, ${ }^{17}$ was more than just "'a man of jest'" (TS, 4.27.324), Tristram claims that his "hero's" character was "temper'd with something which witheld . . him from ... many ... ungracious pranks, of which he ... undeservedly bore the blame" (IS, 4.27.324). Because "his spirit was above it," Tristram adds, Yorick refused to deny false accusations which "he could have explained... to his honour" (TS, 4.27.324). Instead of setting himself right in the eyes of the world, Yorick "trusted to time and truth to do it for him" (TS, 4.27.324). In telling the story of Yorick's brief life, Tristram may be seen as executing this trust, for like Erasmus' Stultitia, he shows that what this world calls folly may well lead to wisdom.

Not only does Tristram show that folly may lead to wisdom, but he also shows that false learning may pervert wisdom into folly. Tristram is a wise fool because he sees both the wisdom in folly and the folly in wisdom. In his "Author's Preface," which appears between chapters twenty and twenty-one of Volume III, Tristram addresses himself to the issue of false learning when he says that "the main and principal point I have undertaken to clear up... is, How it comes to pass, that your men of least wit are reported to be men of most judgment" (TS, 3.20.200). For Locke, wit lies "most in the assemblage of ideas, and putting those together with quickness and variety, wherein can be found any resemblance... judgment, on the contrary, lies quite on the other side, in separating carefully, one from another, ideas wherein can be found the least difference."18 In disagreement with Locke, Tristram argues that there is as little difference between 
wit and judgment as there is between "farting and hickuping" (TS, 3.20.193). As Tristram indicates by his choice of similes, he wishes to reduce to absurdity the claims of worldly wise men, such as "Agelastes," "Triptolemus," and Phutatorius," 19 which forced Locke to make his distinction between wit and judgment. Tristram's "Author's Preface," which openly invites comparison to the "Author's Prologue" in Book I of Rabelais, ${ }^{20}$ deals with Locke's distinction in order to show how the practitioners of false learning can pervert wisdom into folly. The object of Tristram's satire here is not "the great Locke," who "freed the world from the lumber of a thousand vulgar errors" (TS, 3.20.202), but the false learning and worldly wisdom of the "graver gentry" (TS, 3.20.201) who duped or "bubbled"(TS, 3.20.202) Locke into making his distinction.

In showing how Locke was "bubbled" into making his distinction between wit and judgment, Tristram explains that since the "graver gentry" realized that they lacked wit, they appropriated judgment to themselves and successfully persuaded Locke to make his distinction between wit and judgment in favor of the latter. Tristram's description of the manner in which the "graver gentry" beguiled Locke into making his distinction indicates Tristram's low opinion of worldly wisdom:

I need not tell your worships, that this was done with -. such cunning and artifice... The cry [i.e., of the "graver gentry,"7, it seems, was so deep and solemn a one, and what with the help of great wigs, grave faces, and other implements of deceit, was rendered so general a one against the poor wits in this matter, that the philosopher himself Ii.e., Locke was deceived by it (TS, 3.20.202). 
By discrediting the manner in which the distinction between wit and judgment was made, Tristram discredits the distinction itself as "one of the many vile impositions which gravity and grave folks have to answer for hereafter" (IS, 3.20.202).

By recognizing that Locke's distinction between wit and judgment resulted from the pressures brought to bear by the worldly wise "graver gentry," Tristram shows that he is wiser than his cap and bells might indicate. He also shows that he is a wise fool by avoiding a "set dissertation" (TS, 3.20.200), such as Locke's distinction between wit and judgment, because such a distinction would involve "placing a number of tall, opake words, one before another... betwixt [his] own and [his Instead of relying upon the philosophical rhetoric of a "set dissertation, "Tristram utilizes the two knobs on the back of his "cane chair" to illustrate that the isolated presence of either wit or judgment merely emphasizes the absence of the other:

Now would any man who valued his character a straw, have turned a piece of work out of his hand in such a condition? -- nay, lay your hands upon your hearts, and answer this plain question, Whether this one single knobb [sic7 which now stands here like a blockhead by itself, can serve any purpose upon earth, but to put one in mind of the want of the other? (TS, 3.20.201)

In order to justify his use of two knobs on the back of his chair as a means of illustrating the extent to which Locke was fooled into making his distinction, Tristram quotes from Book III of Rabelais: "'for what hindrance... doth the laudable desire of knowledge bring to any man, if even from a sot, a pot, a fool, a stool... or a cane 
chair, 1" (TS, 3.20.200)..$^{21}$ As Indicated by his quotation from Rabelais, Tristram is asking the reader to identify him with other wise fools who have imparted lessons of wisdom.

Tristram's satire on Locke's distinction between wit and judgment in his "Author's Preface" serves as a parable for the entire novel. By showing how the "grave folks" (IS, 3.20.202) of this world can beguile someone like the "sagacious Locke" (TS, 1.5.9) into accepting false reasoning as true wisdom, Tristram alerts the reader to the dangers posed to society by false learning. His exposé of "gravity and grave folks" for beguiling Locke into distinguishing between wit and judgment is a Shandean variation upon Milton's theme of the abuse of carnal knowledge. More particularly, Tristram's warning to the reader is analogous to Raphael's warning to Adam in Paradise Lost, that the abuse of carnal knowledge "soon turns/Wisdom to Folly" (VII, 129-30). Tristram's "Author's Preface," then, reminds the reader that the "knowledge" which emerges from the mouths of "grave folks" may well be folly, whereas the knowledge which comes from "a fool" (IS, 3.20.200) may well lead to wisdom.

Walter Shandy's hypotheses likewise demonstrate how worldly wisdom may lead to folly. Tristram describes his father as a "philosopher in grain--speculative--systematical" (TS, 1.21.68), whose way "was to force every event in nature into an hypotheses, by which means never man crucified TRUTH at the rate he did" (TS, 9.32.644). Walter's theory of auxiliary verbs, which is part of his Tristrapoedia, or "system of education" for Tristram (IS, 5.16.372), 
exemplifies his "crucifixion" of truth. Hoping to salvage his son from the misfortunes of his misconception, crushed nose, and misnaming, Walter fabricates his theory that auxiliary verbs are "a North-west passage to the intellectual world" (TS, 5.42.404). The folly of Walter's faith in his theory of auxiliary verbs is seen in his claim that the "right use" of auxiliary verbs will allow Tristram to convert "every word .. Into a thesis or hypothesis" (TS, 6.2.409). "No one idea can enter [Tristram's 7 brain how barren soever, "Walter asserts, "but a magazine of conceptions and conclusions may be drawn from it" (TS, 5.43.406).

Walter attempts to demonstrate his assertion that auxiliary verbs are a short-cut to the intellectual world in the "white bear" scene at the end of Volume $\mathrm{V}$ of Tristram Shandy. As John Stedmond points out, Walter attempts to demonstrate "the efficacy of his method by showing how Trim might discourse on a white bear without ever having seen one" (Stedmond, p. 115). In the first part of his demonstration, Walter runs through a partial conjugation of the verb to see, using the auxiliary verbs have, be, ought, would, and should:

A WHITE BEAR! Very well. Have I ever seen one? Might I ever have seen one? Am I ever to see one? Ought I ever to have seen one? Or can I ever see one?

Would I had seen a white bear! (for how can I imagine it?)

If I should see a white bear, what should I say? If

I should never see a white bear, what then? (TS, 5.43.406-07)

In the second part of his demonstration, however, Walter seems to disprove his assertion about auxiliary verbs. Whereas the grammatical emphasis in the first part of Walter's discourse is upon 
the auxiliary verbs have, be, ought, would, and should, the grammatical emphasis in the second part shifts to a variation of adjectives (alive, painted, described), nouns (father, mother, uncle, aunt, brothers, and sisters), and predicate adjectives (wild, tame, terrible, rough, and smooth):

If I never have, can, must or shall see a white bear alive; have I ever seen the skin of one? Did I ever see one painted? --described? Have I never dreamed of one? Did my father, mother, uncle, aunt, brothers or sisters, ever see a white bear? What would they give? How would the white bear have behaved? Is he wild? Tame? Terrible? Rough? Smooth? (TS, 5.43.407)

In the conclusion of his discourse, Walter raises evaluative and theological questions when he asks whether the white bear is "worth seeing," whether there is any "sin" in seeing one, and whether seeing a white bear is better than seeing "a BIACK ONE" (TS, 5.43.407)。 Because he has distorted a simple grammatical exercise in the use of auxiliary verbs into an absurd philosophical discourse involving questions of value judgment and theology, Walter has disproved his assertion that auxiliary verbs are a short-cut to the inteliectual world; in spite of himself, he has succeeded in showing how his worldly wisdom has perverted truth by imposing an untenable hypothesis upon reality.

The failure of Walter's theory of auxillary verbs, which constitutes a chapter in his Tristra-poedia, is emblematic of the failure of the Tristra-poedia as a whole. In spite of his expectations about its educational value, Walter's "system of education" does not accomplish its task of redeeming Tristram from the ill effects of his 
misconception, crushed nose, and misnaming. Ironically, Walter spends so much time on his Tristra-poedia that Tristram's education is left to his mother, a woman whose lack of interest in intellectual pursuits is suggested by her habit of "using a hard word f for 7 twenty years ... and replying to it too ... without giving herself any trouble to enquire about it" (TS, 9.11.613). Furthermore, Tristram points out, one half of Walter's system of education was outdated by the time that it was ready to be used:

That is the best account I am determined to give of the slow progress my father made in his Tristra-poedia; at which (as I said) he was three years and something more, indefatigably at work, and at last, had scarce compleated [sic7, by his own reckoning, one half of his undertaking: the misfortune was, that I was all that time totally neglected and abandoned to my mother; and what was almost as bad, by the very delay, the first part of the work, upon which my father had spent the most of his pains, was rendered entirely useless, --every day a page or two became of no consequence (TS, 5.16.375).

The fallure of Walter's Tristra-poedia epitomizes the foolishness of worldly wise schemes which fail to square with the realities of human experience. In his comment upon the failure of his father's educational scheme, Tristram again reveals his wise foolishness by recognizing the Tristra-poedia as a moral lesson in the dangers of human pride: "Certainly it was ordained as a scourge upon the pride of human wisdom, That the wisest of us all, should thus outwit ourselves, and eternally forego our purposes in the intemperate act of pursuing them" (TS, 5.16.375).

The Tristra-poedia's lack of success also illustrates the fallure of the "speculative man" described in Sterne's sermon, 
"Advantages of Christianity to the World," to make the Augustinian distinction between wisdom and knowledge. In his sermon, Sterne applies his Pauline text--"Professing themselves to be wise, they became fools" (Rom. 1.22)--to those "pretenders [who7 think our titles to wisdom built upon the same basis with those of our knowledge, and that they will continue for ever" (Sermons, II, 55). To the foolish "speculative man," Sterne continues, true "wisdom dwells ... in finding out the secrets of nature; sounding the depths of arts and science, measuring the heavens" (Sermons, II, 55). Reminiscent of the Triboullet-Panurge episode in Book III of Rabelais, Tristram's recognition of the foolishness of Walter's worldly wisdom amounts to one fool calling another foolish. ${ }^{22}$ While both Tristram and Walter are fools, they are different kinds of fools. ${ }^{23}$ Tristram's comment upon the foolish vanity of Walter's Tristra-poedia and his observation that Walter "crucified" truth indicates that Tristram is a "wise fool" because he recognizes that in worldly wisdom there is folly. As I hope to show in Chapter IV of this study, Tristram's failure to achieve the transcendent wisdom of Christ results, paradoxically, from his failure to be foolish enough. Walter, on the other hand, has been made foolish by his useless, pedantical learning. In Pauline-Erasmian terms, Tristram professes to be a fool and emerges with some degree of wisdom; Walter professes to be wise, and becomes a fool.

In commenting upon his father's speculative schemes, Tristram does not inveigh against them so much as he ridicules them with a 
laughter moderated by sympathy. While pointing out that "where an hypothesis was concerned," Walter gave more pain than he received, Tristram at the same time observes that his father was "frank and generous in his nature [and] at all times open to conviction" (TS, 2.12.114). Sterne's sympathy for his characters in Tristram Shandy and tolerance for their obsessions, ranging from Walter's speculative flights to Tristram's hobby-horsical hypotheses about writing in his "own way" (TS, 2.6.11), prevents him from engaging in the sharp invective characteristic of the Augustan satirists. "The propensity of ridicule to overreach itself," A. E. Dyson has pointed out, "is exactly one of those things which Sterne's ridicule sets out to check." 24 In the tradition of Erasmus, whose "sense of humanity" all but excluded the possibility for "railing satire, 125 Sterne loves and accepts his characters or "dear creatures" (TS, 5.9.364) for what they are. By accepting human nature, foolish as it may be, Sterne calls attention to his greater wisdom in siding with the wise fool Stultitia who claimed that "to live in folly . . is what it is to be human" (Folly, p. 122).

Far from viewing Walter's hypotheses as threats to society, Tristram views them as signs of man's foolish, but natural attachment to his hobby-horse. Man's attachment to his hobby-horse is so natural, Tristram argues, that from "a clear description of Its nature, " one could "form a pretty exact notion of the genius and character" of its rider (TS, 1.24.77). Early in his story, Tristram observes that 
. . the wisest of men in all ages, not excepting Solomon himself, --have . . had their HOBBY-HORSES; --their running horses, --their coins and their cockle-shells.. --their maggots and their butterflies--and so long as a man rides his HOBBY-HORSE peaceably and quietly along the King's highway, and neither compels you or me to get up behind him, --pray, Sir, what have either you or I to do with it? (TS, 1.7 .13 )

Soon after making his observation about the popularity of hobbyhorses among wise men, Tristram states that he himself is not exempt from riding one:

Be it known to you, that I keep a couple of pads myself, upon which, in their turns, (nor do I care who knows it) I frequently ride out and take the air; -- tho ${ }^{\text {s }}$ sometimes, to my shame be it spoken, I take somewhat longer journies than what a wise man would think altogether right. --But the truth is, --I am not a wise man (TS, 1.8.14)。

Tristram's claim that he is "not a wise man" is offset by the conclusion which follows from his statement about owning a hobbyhorse himself。 ${ }^{26}$ Because he recognizes that he, like the "wisest of men in all ages" has a hobby-horse, then he is not as foolish as he may at first appear. Indeed, Tristram's observation that hobbyhorses are harmless as long as a man does not become obsessed with one implies a distinction between the natural condition of possessing a hobby-horse and the unnatural condition of being possessed by one. Tristram later makes this distinction between possessing a hobby-horse and being possessed by one explicit when he warns that "when a man gives himself up to the government of a ruling passion, --or, in other words, when his HOBBY-HORSE grows head-strong, --farewell cool reason and fair discretion!" (TS, 2.5.93) Tristram's observation that hobbyhorses, in spite of their apparent foolishness, have traditionally 
been the natural possessions of wise men echoes what Walter Kaiser has called Erasmus' "belief in the benevolence of the force of nature in man" (Kaiser, p. 95). Because Tristram shares Erasmus' conviction that man's natural inclination toward folly is not an inclination toward evil, he would support Stultitia's claim that "if it is . . natural to be a fool, to be a fool is also to be natural." ${ }^{27}$

In spite of his Erasmian tolerance for man's natural foolishness, Tristram ridicules his father's speculative hypotheses because Walter has allowed them to become an unnatural obsession. In distinguishing his hobby-horse from his father's, Tristram says:

I must here observe to you, the difference betwixt My father's ass and my hobby-horse--in order to keep characters separate as may be, in our fancies as we go along.

For my hobby-horse . . Is no way a vicious beast; he has scarce one hair or lineament of the ass about him--'Tis the sporting little filly-folly which carries you out for the present hour--a maggot, a butterfly, a picture... or an any thing, which a man makes a shift to get a stride on, to canter it away from the cares and solicitudes of life --'Tis as useful a beast as is in the whole creation--nor do I really see how the world could do without it--

--But for my father's ass . . . mount him not: --'tis a beast concupiscent--and foul befall the man, who does not hinder him from kicking (TS, 8.31.584).

Walter is the wrong kind of fool, Tristram seems to be saying, not because his hobby-horse is speculative hypotheses, but because he is so obsessed with his hobby that he has become its slave. Also implicit in Tristram's statement distinguishing his hobby-horse from his father's is an appeal to the reader to recognize that he, too, will become a fool like Walter Shandy if he lets his hobby-horse possess him. For Sterne, John Traugott has observed, hobby-horsical 
schemes such as Walter's "can be the death of society... only when men refused to recognize themselves as fools. His rhetoric, like that of Erasmus, invites the reader to acknowledge himself as fool" (Traugott, p.20)。

Although Tristram implies that man must recognize his natural bent toward folly in order to prevent himself from becoming the wrong kind of fool, Tristram does not assume that he is wise and everyone else is foolish. Even if Tristram the narrator is wiser than Walter, Toby, Trim, and the reader, he rarely forsakes the traditional garb of the fool. Sitting in his study at the beginning of Volume IX, Tristram informs the reader that on "this twelfth day of August, 1766," he, Tristram, is dressed "in a purple jerkin and yellow pair of slippers" (TS, 9.1.600). ${ }^{28}$ speaking as a fool among fools, Tristram asks "Madam" the reader, "Pray reach me my fool's cap--I fear you sit upon it.. 'tis under the cushion--I'll put it on--Bless me! you have had it upon your head this half hour--There then let it stay" (TS, 7.26. 511). Because Tristram, like Stultitia, identifies himself with his fellow fools, he can remain compassionate towards those whose folly he ridicules.

In The Sermons of Mr. Yorick, Sterne's appropriation of the pseudonym Yorick, some ten years after nearly all of his sermons were written, ${ }^{29}$ does not offset their didactic tone. Alan McKillop reminds us that "It is in The Sermons of Mr. Yorick rather than in Shandy that 
we find ourselves firmly established in the world of the eighteenth century didactic novel." 30 Whereas Mr. Yorick of the Sermons often castigates man's vain desire to achieve a reputation for wisdom, Tristram, who speaks as a fool among fools, ridicules man's faith in worldly wisdom.

"There is no one project to which the whole race of mankind is so universally a bubble, as to that of being thought Wise," Yorick says at the beginning of "Advantages of Christianity to the World." Later in the same sermon, the preacher continues to castigate human pride by asserting that "in general you will find it safer to tell a man, he is a knave than a fool" (Sermons, II, 53-4). In another sermon, "The Ways of Providence Justified to Man," Yorick holds a mirror up to the self-professed wise men of this world in order to expose the limitations of worldly wisdom when seen against the standard of divine wisdom:

Go then, --proud man!--and when thy head turns giddy with opinions of thy own wisdom, that thou wouldst correct the measures of the AIMIGHTY, --go then,--take a full view of thyself in this glass; --consider thy own faculties,-how narrow and imperfect; --how much they are checquered with truth and falsehood; --how little arrives at thy knowledge, and how darkly and confusedly thou discernest even that little as in a glass (Sermons, II, 254-55).

In a third sermon, "Job's Account of the Shortness and Troubles of Life, Considered," Yorick expresses the traditional Christian view of human pride when he admonishes man to "cloath him $\sqrt{\mathrm{self}}]$ with humility, which is a dress that best becomes a short-lived and a wretched creature" (Sermons, I, 124 ). 
In Tristram Shandy's World, John Traugott argues that St. Paul's warning to the Romans ("Professing themselves to be wise, they became fools") is "Sterne's text in the profane as well as sacred pulpit" (Traugott, p.25)。Although Traugott's argument is essentially correct, it fails to point out the difference in tone between Tristram Shandy and the Sermons. In Tristram Shandy, Sterne, through his narrator, Tristram, not only exposes the folly in worldly wisdom; he exhibits an Erasmian tolerance for folly as well. The more tolerant tone of the novel is suggested by Tristram's emphasis upon his role as a fool and de-emphasis of his actual profession as a priest. 31 In repeatedly referring to his fool's garb rather than his clerical robes, Tristram indicates his desire to project himself as a fool instead of as a clergyman. This emphasis upon his identity as a fool suggests that the novel contains a greater tolerance for folly than the Sermons do for the two basic reasons that we have seen: one, because Tristram shows that a self-styled "fool" can be wise; and two, because he shares Stultitia's conviction that to be foolish is to be natural. Even though he may "preach" upon the same Pauline text as Mr. Yorick of the Sermons, then, Tristram's "preaching" is based upon a greater sympathy for the follies of mankind.

Sterne's tolerance for the foolishness exhibited by his characters distinguishes him from the Augustan satirists who preceded him. In his comment upon the "white bear" scene at the end of Volume $V$ of Tristram Shandy, Martin Price compares Walter to the "priest of Pope's Dulness" for succeeding in "confining the mind to words alone." 32 
Price's comparison is correct only if one fails to note that neither Sterne's compassion for his characters nor his tolerance for folly is contained in Pope's savage attack upon the dunces in the Dunciad. From the viewpoint of the Augustans, Walter's attempt to reduce reality to words, as reflected in his theory of auxiliary verbs, would represent the same danger to society as the schemes of the dunces in Book IV of the Dunciad, to separate words from ideas useful to the whole man. 33 Walter's abuse of language would, for Pope, not be far removed from that of the "school-master," who claims that "Since Man from beast by Words is known/ Words are Man's province, Words we teach alone" (IV, 149-50). While observing that "Tristram Shandy, in its way, is an extension of Pope's vision" in the Dunciad, John Stedmond argues that Sterne's

- approach is much more tentative, his attack much less bitter--presumably because his positive beliefs are much less surely held. Swift's writings "express" ideas, or communicate firmly held points of view, by attacking opposing ideas. Sterne, on the other hand, is seeking to reveal states of mind. Swift attacked the Grub Street hack by parodying his style; Pope sallied against the pedantic dunce by burlesquing his method; and Sterne, in his turn, donned cap and bells in order to show up foolishness by playing the fool (Stedmond, pp. 64-5).

In view of Pope's savage attack in the Dunciad upon the forces of Dulness responsible for threatening to destroy the humanistic tradition of western civilization, 34 there is little cause for disagreement with Stedmond's argument that Sterne's approach is more equivocal and his attack less bitter than that of his Augustan predecessors. As we have seen, Sterne's method of ridiculing folly 
by speaking through a fool, Tristram, results in a less bitter tone than if the novelist had chosen to satirize human folly virulently in Tristram Shandy. On the basis of what has been shown about Tristram's wise folly, however, there is reason to challenge Stedmond's assumption that "show/ing] up foolishness by playing the fool" illustrates that Sterne's "positive bellefs are much less surely held" than Swift's and Pope's. Sterne's particular method of ridiculing folly indicates that he accepts man's natural inclination toward folly because he, Sterne, is wise enough to recognize that fools differ from wise men only in degree. As Ernest Tuveson has succinctly pointed out, "the pride satirized [in Tristram Shandy] is not that which Swift or Pope had attacked.. [Sterne7 seeks to correct our smug assumption that all within our heads is neat and orderly, and that the mad and even the eccentric are different in kind from ourselves." 35

For Sterne, "playing the fool" by speaking through his foolish narrator, Tristram, reflects a positively held belief about the universal existence of folly in all men, including himself. Sterne's positive purpose in "playing the fool" by speaking through Tristram sets him apart from the distrustful Augustan attitude toward foolishness suggested in Pope's observation that although "a little [folly] is excellent ... a whole Mouthful is justly call'd the Devil." 36 As seen in his statement that "the greatest advantage . . of being thought a wit by the world is, that it gives one the greater freedom of playing the fool, "37 Pope considered "playing the fool" less a positive virtue in itself than a useful advantage in a witty man. It 
appears unlikely, then, that Pope would risk subjecting himself to the charges of frivolity leveled against Sterne when, through both Tristram and Yorick, he "played the fool" in Tristram Shandy in order to show that fools may impart lessons of wisdom. 38

Sterne's tolerance for the kinds of worldly wisdom exhibited by the Shandeans, however, did not extend to the kinds exhibited by the canonical divines, Didius, Phutatorius, and Kysarcius. To Sterne, the kinds of worldly wisdom exhibited by these "vile canonists" (TS, 4.23.302) at the canonical dinner in York represented a clearer danger to man than the danger posed by Walter because, in perverting their clerical function of preparing man for the next world, the "vile canonists" could more easily prevent man from achieving the wisdom of Christ. Together with Yorick, who is to deliver a sermon before the visiting clergy, Walter and Toby attend the canonical dinner hoping to annul Tristram's baptism. By bringing the Shandy brothers and Yorick face to face with the learned canonical divines, Sterne creates a symposium attended by spokesmen and critics of various kinds of worldly wisdom. The York dinner brings the Shandy brothers and Parson Yorick, the enemy of "vile canonist/s]" (TS, 4.23.302), together with such representatives of worldly wisdom as Didius, "the great church lawyer" (TS, 3.20.193); Kysarcius, ("probably Sterne's translation of Baise-cul, a 'great lord' in Rabelais, 2.10-13"); 39 and Phutatorius, the licentious churchman. 40 The York dinner-meeting is analogous to the symposium in Book III of Rabelais to the extent that each is a colloquy addressed to a major question concerning one of the characters: 
Pantagruel calls the symposium in Book III to debate the issue of Panurge's marriage, and the York dinner provides Walter with the opportunity to seek the annulment of Tristram's baptism. While the symposium in Rabelais dramatizes the limitations of worldly wisdom, ${ }^{41}$ the York dinner in Tristram Shandy dramatizes the perversions in reason which manifest themselves in what the world calls wisdom.

The canonical dinner at York begins with Yorick's tearing up of the sermon he had planned to deliver, because it "came from [his head instead of /his 7 heart" (TS, 4.26.317). Yorick's criticism of abstract, pedantical preaching--"'tis not preaching the gospel--but ourselves" (TS, 4.26.317)--is interrupted when Phutatorius cries out in pain after being burned by a hot chestnut. A humorous, almost slapstick scene results, as the participating clergy debate whether or not Yorick was responsible for having dropped a hot chestnut into the opening in front of Phutatorius' breeches. For some, Yorick's picking the hot chestnut up after it had fallen out of Phutatorius' breeches implicates Yorick as the prankish wrongdoer. This circumstantial evidence about Yorick's guilt, in turn, provides ballast for the churchmen's hypothesis that there was a "mystical meaning in Yorick's prank" (IS, 4.27.323) of dropping the chestnut into Phutatorius' breeches, since Yorick held Iittle respect for Phutatorius' "filthy and obscene treatise" (TS, 4.27.321) on the keeping of concubines.

Tristram's comment that the conjecture of the learned divines about the "mystical meaning" of Yorick's prank "was as groundless as 
the dreams of philosophy" (TS, 4.27.324) indicates Tristram's low opinion of the absurd uses to which the clergymen put their learning. It is worthy of note that Tristram had earlier avoided direct comment upon his colleagues' abuse of wisdom:

As for the clergy--No--If I say a word against them, I'll be shot. --I have no desire,--and besides, if I had, --I durst not for my soul touch upon the subject, --with such weak nerves and spirits, and in the condition I am in at present, 'twould be as much as my life was worth, to deject and contrist myself with so sad and melancholy an account (TS, 3.20.199).

Tristram's cautiousness in refraining from direct criticism of his fellow clergy epitomizes the more prudent, and thus, less "foolish," nature of his satire upon worldly wisdom. Whereas Yorick does not hesitate to lash out at the foolishness of the worldly wisdom exhibited by his colleagues at the canonical dinner, Tristram claims that "tis safer to draw a curtain across" (TS, 3.20.200) the Anglican priesthood's misuse and abuse of human wisdom。

Both Phutatorius' treatise on keeping concubines and the absurd attempt of the canonical divines to impose a "mystical meaning [upon] Yorick's prank" thus dramatize the way in which Yorick's fellow priests have allowed worldly wisdom to pervert the proper duties of their clerical office. For Yorick, such displays of worldly wisdom as Phutatorius' treatise on concubines had to be exposed "as thing which . . had done hurt in the world" (TS, 4.27.323). The abuses in clerical learning exhibited by Phutatorius' treatise pale in comparison to the debate over the legality of Tristram's baptism, however. Citing a pre-Reformation precedent, the Duchess of Suffolk's case, the 
canonical lawyers rule that the wishes of Mr. and Mrs. Shandy concerning their son's Christian name are irrelevant, since the parents are not of kin to their child (TS, 4.29 .328 ).

Sterne castigates such abuses in learning for beguiling man into believing in false wisdom at the expense of genuine learning. One of his aims in writing Tristram Shandy, Sterne once remarked, was "the hopes of doing the world good by ridiculing what I thought deserving of it--or of disservice to sound learning" (Letters, No. 47, p. 90). The extent to which man is beguiled by false wisdom becomes evident in Walter's reaction to the canonical debate about Tristram's baptism. Although Walter is at first "hugely tickled with the subtleties of these learned discourses" (TS, 4.31.331) about the legality of his son's baptism, his pleasure soon gives way to despair. Both the symposium in Book III of Rabelais and the canonical dinner end without resolving the issues proposed at the outset. Panurge's disappointment at the end of the symposium, resulting from his failure to find satisfaction in the counsels of the worldly wise, is similar to Walter's disappointment at the end of the York visitation dinner. While Panurge's expression reminds Pantagruel of "a mouse caught in a trap" (Rabelais, 3.37.390), Walter is bent over with "the weight of his afflictions," which returned "upon him but so much the heavier" (TS, 4.31.331)。

Whereas Walter is temporarily stimulated by the "subtleties" of the ecclesiastical court, Toby and Yorick expose the foolishness of its worldly wisdom. Yorick's reply to Toby's question about the 
court's decision on Tristram's baptism indicates his contempt for the worldly wisdom of the "vile canonists" (TS, 4.23.302):

--And pray, Yorick, said my uncle Toby, which way is this said [sic] affair of Tristram at length settled by these learned men? Very satisfactorily, replied Yorick; no mortal, Sir, has any concern with it (TS, 4.30.331).

Wilbur Cross makes a good case for reading the canonical dinner as "local satire," particularly upon Dr. Francis Topham, a Machiavellian church lawyer, whose political machinations in the York parish were unalterably opposed by Sterne. 42 According to Sterne's biographer, "Topham surely appeared as Didius and shifted into Phutatorius before the dinner was over" (Iife, pp. 261-62). In addition to being read as "local satire," the canonical dinner may be seen as a concrete illustration of Gregory's distinction between "noble" fools (those who reject this world's wisdom for the wise foolishness of God) and "base" fools (those who "flee from the wisdom Above" by following themselves). 43 The canonical dinner begins and ends with Yorick's castigating the way in which his fellow clergymen abuse their clerical office. We recall that at the outset of the dinner, Yorick castigates his colleagues for preaching themselves rather than the gospel (TS, 4.26.317) and that he exposes their pedantical practice of writing "from the head" instead of from the "heart" by tearing up his own pedantical sermon into shreds. Just as dramatic is his method of bringing the meeting to a close. During the debate about the legality of Tristram's baptism and the consanguinity of the parents to their child, Didius claims that the prohibition in levitical law of copulating with one's grandmother 
does not apply "in nature." In reply to Kysarcius' question--"But who ever thought.. of laying with his grandmother?" (TS, 4.29.330) -Yorick cites a story recorded in John Selden's Table Talk: 44

The young gentleman ... whom Selden speaks of--who not only thought of it, but justified his intention to his father by the argument drawn from the law of retaliation--"You lay'd, Sir, with my mother, said the lad--Why may not I lay with yours?" --'Tis the Argumentum commune, added Yorick, --'Tis as good, replied Eugenius, taking down his hat, as they deserve.

The company broke up-- (IS, 4.29.330-31).

Yorick's function of castigating the proud again becomes evident in his description of "polemic divines." Wishing that there "was not a polemic divine... in the kingdom," Yorick tells Walter that "one ounce of practical divinity--is worth a painted ship load of all their reverences have imported these fifty years" (TS, 5.28. 387). Yorick further ridicules "polemic divines" by comparing their mental gymastics to the tumbling feats of the Rabelaisian characters Gymnast and captain Tripet. ${ }^{45}$ The point of Rabelais' story is to show the irrelevancy of Gymnast's tumbling tricks to the battle he fights with Tripet. In his slightly altered version of the story, Yorick, who carries a copy of Rabelais in his pocket, describes how the two combatants "battle" without striking a blow. In the context of Yorick's version of Rabelais' story, polemic divines are satirized for their reliance upon pedantic and irrelevant mental gymnastics at the expense of executing their proper function of "practical divinity"-preparing man for the next world by teaching him right conduct in this. Trim's frustration with Yorick's account of Gymnast's curious way of doing battle--"Good God! . . . one home thrust of a bayonet is 
worth it all" (TS, 5.29.389)--corresponds to Yorick's contempt of churchmen whose worldly wisdom lacks "one ounce of practical divinity." Significantly, Yorick agrees with Trim's comment, while Walter is of a "contrary opinion" (TS, 5.29.389).

By reducing the canonical debate over the legality of Tristram's baptism to absurdity, and by ridiculing the pretensions of "polemic divines," Yorick thus exhibits what Henri Fluchere calls the court jester's traditional function of "castigating the proud" (Fluchere, p. 444). While the York dinner reveals Yorick functioning in the satiric capacity of castigating the vain churchmen who preach themselves instead of the gospel, it also reveals him as a model of the type of humility traditionally praised by the exponents of Christian folly. Yorick, like the "noble" fools praised by Gregory, would rather preach the gospel than himself, and his theory of preaching as a direct appeal to the heart recalls the anti-scholasticism of Stultitia in The Praise of Folly.

Toby's humility and lack of intellectual pretension also exposes the folly of the worldly wise debates taking place at the York dinner. When Kysarcius pompously cites the Duchess of Suffolk's case as the precedent establishing that "the mother is not of kin to the child" (TS, 4.29.328), Toby asks: "And what said the duchess of Suffolk to it?" In "confound_ing] Kysarcius more than the ablest advocate" (TS, 4.29.330), Toby's question may be seen as a concrete illustration of the warning enunciated by Paul and the Old Testament prophets that the simple and unlearned shall destroy the wisdom of the wise. 
As will become more evident in Chapter III of the present study, the corrective wisdom of the novel's simple, but wise fools, such as Toby and Trim, complements the satirical ability of Tristram and Yorick in their "open war" on the "affectation of gravity." Foils to the worldly wisdom of the novel's pedants, Trim and Toby function as unlearned instruments of divine wisdom and prepare us for the victory of wise folly's most perfect form in Tristram Shandy--the transcendent wisdom of Parson Yorick's Christian folly. Like Tobias in the apocryphal Book of Tobit, who brings the power of sight to his father, Tristram's uncle, Toby, helps bring the illuminating power of wise folly to Shandy Hall by showing that the proud spirit of reason must be vanquished before man may become a receptacle worthy of the wisdom of Christian folly. 
1. In Yorick and the Critics: Sterne's Reputation in England, 17601868 (New Haven, Conno, 1958), Alan B. Howes observes that "Yorick, Tristram Shandy, and Laurence Sterne became hopelessly entangled in the public mind" ( $p .5)$ upon publication of the first installment of Tristram Shandy in December, 1759.

2. The Life and Opinions of Tristram Shandy, Gentleman, ed. James A. Work (New York, 1940), Vol. II, chap. il, p. 86. AII subsequent references are to this edition.

3. See Howes, pp. $4 \mathrm{ff}, 9 \mathrm{ff}$, ana $24 \mathrm{ff}$, for a discussion of Yorick's character by Sterne's contemporaries. According to Howes, the Royal Female Magazine for February, 1760 described "the character of Yorick to illustrate the 'consequences of indiscretion and the licentious indulgence of satirical wit'" ( $p .4)$.

4. Wilbur L. Cross, The Life and Times of Laurence Sterne, 3rd ed. (New Haven, Conn., 1929), p. 2--hereafter cited as Iife.

5. Norman N. Holland, "The Laughter of Laurence Sterne," Hudson Review, IX (1956), 430。

6. Henri Fluchère, Laurence Sterne: From Tristram to Yorick, an Interpretation of "Tristram Shandy," trans. Barbara Bray (London, 1965), p. 273.

7. For a brief discussion of Tristram as a court jester in the Erasmian tradition, see John Traugott, Tristram Shandy's World (Berkeley and Los Angeles, 1954), pp. 39, 138-39.

8. Letters of Laurence Sterne, ed. Lewis P. Curtis (Oxford, 1935), Number 36, p. 74. A?I subsequent references to Sterne's letters are to this edition and will hereafter be cited as Letters.

9. See Chapter I, above, pp. 2l-23.

10. In "Laurence Sterne, Apostle of Laughter," in The Age of Johnson: Essays Presented to Chauncey Brewster Tinker, ed. Frederick W. Hilles (New Haven, Conn., 1949), Rufus D. S. Putney reminds us that Sterne "possessed an impulse to folly that had driven him, while his reputation was merely local, to play the fool agriculturally, politically, clerically, and domestically"(p. 166). 
11. In The Comic Art of Laurence Sterne (Toronto, 1967), John Stedmond points out that with the publication of the first selection of The Sermons of Mr. Yorick "between the publication of the first two volumes Lof Tristram Shandy7 and the second two," Sterne "could now count on his readers to think of him as a clergyman, to some extent equivalent to Yorick, and thus not to identify him with Tristram, or only in so far as he could be imagined as deliberately donning cap and bells for the performance" ( $p .90)$.

12. William Warburton's relationship to Sterne is a case in point. Although he patronized Sterne after the novelist's triumphant visit to London in 1760 as the successful author of Tristram Shandy, Warburton soon became concerned about the effect of Sterne's "playing the fool" upon his clerical reputation. Writing to David Garrick, Sterne's friend and admirer, Warburton said of the novelist: "I have done my best to prevent his playing the fool in a worse sense than, I have the charity to think, he intends. I have discharged my part to him. I esteemed him as a man of genius, and am desirous he would enable me to esteem him as a clergyman" (quoted by Howes, pp. 6-7).

13. At the beginning of her praise of folly, Stultitia says to her audience: "The reason why I appear today in this unusual garb you will presently hear, if you listen to me with attention; not as you do in sermons, but as you do to salesmen in the market, to clowns and jesters" (Folly, p. 101).

14. According to Cross, Sterne endorsed a manuscript copy of his sermon "Our Conversation in Heaven" with the following memorandum: "Made for All Saints and preached on that Day 1750 for the Dean. --Present: 1 Bellows Blower, 3 Singing men, 1 Vicar \& 1 Residentiary" (quoted in Iife, p, 620).

15. Quoted by Cross, Iife, p. 236.

16. Stultitia's statement that her "face and visage 。. tell well enough who I am" must be read in the ironic context of her next remark: "As if anyone, who thought I was Minerva, or Wisdom, could not easily be convinced otherwise by only looking at me" (Folly, pp. 102-03). Like all wise fools, Tristram and Stultitia intentionally confuse the categories of appearance and reality in order to achieve their transvaluation of the ideas of folly and wisdom.

17. In Hamlet, $v, i, 172-73$, Hamlet says to Horatio as he picks up Yorick's skull, "Alas, poor Yorick! I knew him, Horatio, a fellow of infinite jest."

18. John Locke, An Essay Concerning Human Understanding, 2.11.2, quoted by Work, TS, p. 193, n。2. 
19. James Work points out that Agelastes means "one who never laughs"; Triptolemus, a "judge in the infernal regions"; and Phutatorius, "copulator, lecher" (Work, IS, p. 193, n。1)。

20. Work, TS, p. 194, n. 4.

21. In Tristram Shandy's World, John Traugott observes that "for Shandeans or Rabelaisians there may be a world of significance in a sot, a pot, a fool, a stool" (pp. 70-71).

22. Throughout this section, I am greatly indebted to Walter Kaiser's discussions of the relationship between Panurge and Triboullet on pp. 176-77 of his Praisers of Folly.

23. Cf. Stedmond: "Most of the characters in Tristram Shandy are 'fools,' though they represent different kinds of folly" (p. 92).

24. A. E. Dyson, "Sterne: The Novelist as Jester," Critical Quarterly, IV (1962), 33 .

25. Kaiser, p.99.

26. As Tristram reveals in the middle of his life and opinions, his hobby-horse is his unique way of telling his story: "What a rate have I gone on at, curvetting and frisking it away, two up and two down for four volumes together, without looking once behind, or even on one side of me, to see whom I trod upon!" (TS, 4.20.298) In "The Hobbyhorsical World of Tristram Shandy," MLQ, XXIV (1963), 131-43, Joan Joffe Hall points out that "the exaggeration of the particular ideas in Tristram's train $\sqrt{i} . e_{0}$, of thought 7 and his obsession with the reader define Tristram's own hobby" (139).

27. As Kaiser has shown (Praisers of Folly, p. 95), Stultitia's belief that man is naturaliy foolish becomes explicit at several points in her oration. One such time occurs when Stultitia disagrees with the philosophers who say that "it is misery itself to live in folly, to err, to be deceived, and to be ignorant." "On the contrary," she argues, "this is what it is to be human. I cannot see why they call this kind of life miserable when it is the common lot of all men to be born, brought up, and constituted in such a way. Nothing is miserable that is constant with its own nature" (Folly, p. 122).

28. Tristram refers to his fool's cap in TS, 3.29 .236 and IS, 4.20 .299$.

29. In Laurence Sterne's 'Sermons of Mr. Yorick, ' Lansing Hammond theorizes that "all but one of Mr. Yorick's sermons had been written before 1751, and most of them probably several years before then" 
(p. 58). The first two volumes of The Sermons of Mr. Yorick appeared in May, 1760 .

30. Alan Dugald McKillop, The Early Masters of English Fiction

(Lawrence, Kansas, 1956), p. 190.

31. Tristram reveals that he is a priest when he claims to be worth "two bad cassocks in the world" (TS, 3.11.179). The only other indication of Tristram's clerical profession occurs during his grand tour of the continent when he describes himself as "a person in black, with a face as pale as ashes, at his devotions" (TS, 7.34.527). In spite of Tristram's statement about his "two bad cassocks," Alan Howes is unwilling to accept the evidence that Tristram is a priest. "In Tristram Shandy," Howes writes, "the distinction between Tristram and Laurence Sterne breaks down as early as Vol. 3 (ch. 1l; Work, p. 179), unless we assume that Tristram is a clergyman too" (Howes, p。 5, n. 7).

32. Martin Price, "Sterne: Art and Nature" in To the Palace of Wisdom (Garden City, N. Y., 1964), p. 322.

33. For a discussion of Pope's treatment of the rupture between words and thought, see Aubrey L. Williams, Pope's 'Dunciad': A Study of its Meaning (London, 1955), pp. 111-15.

34. For a discussion of Pope's attack upon the threat to the humanistic tradition of the west in the early eighteenth century, see Williams' study of Pope's Dunciad, particularly chapter six, "The Anti-Christ of Wit," pp. 131-58.

35. Ernest Tuveson, "Locke and Sterne," in Reason and the Imagination: Studies in the History of Ideas, 1600-1800 (New York, 1962), p. 265 .

36. Correspondence of Alexander Pope, ed. George Sherburn (Oxford, 1956), vol. II, p. 315.

37. Quoted by Rufus Putney, "Laurence Sterne, Apostle of Laughter," in The Age of Johnson, p. 166.

38. Alan Howes cites an informative example of the representative Augustan attitude toward indiscretion in "playing the fool" in a letter from Bishop Warburton to Charles York at the time of Sterne's death: "'Poor Sterne... was the idol of the higher mob.. . and7 chose the office of common jester to the many. But what is hard, he never will obtain the frivolous end he aimed at, the reputation of a wit, though at the expense of his character, as a man, a scholar, and a clergyman... He chose swift for his model: but Swift was either luckier or wiser, who so managed his wit, that he will never pass with posterity for a buffoon; while Sterne gave such 
a loose to his buffoonery, that he will never pass for a wit" " (p. 28, n. 5).

39. Work, IS, p. 194, n. 5. In view of Sterne's satire in Vol. IV of Tristram Shandy upon abuses in clerical wisdom, it is worthy of note that his brief Fragment in the Manner of Rabelais satirizes the attempt of "Longinus Rabelaicus" to "compose a thoroughstitch'd system. . of the art of making all kinds of your theological, hebdomical, rostrumical, humdrummical" sermons (The Writings of Laurence Sterne, IV, 183). Cross points out that "The Fragment in the Manner of Rabelais. . appears to have been a discarded digression originally written for the fourth volume of Tristram Shandy" (Life, p. 522).

40. See note 19, above.

41. For a full discussion of the meaning of the symposium in Book III of Rabelais, see Kaiser, pp. 151-62.

42. For a history of Sterne's quarrel with Topham, see Life, pp. 166-74.

43. See Chapter I, above, p. 11.

44. James Work notes that "John Selden (1584-1654), English jurist, antiquary, Orientalist, and author, relates this story in his Table Talk" (TS, p. 330, n. 10)。

45. John Stedmond argues that the point of Yorick's story is to satirize Walter, not the "polemic divines": "Nalter's theories embody as many mental somersaults and caperings as any parabolized by Rabelais in his fable of Tripet and Gymnast" (p. 114). 


\section{Three: The Wisdom of Folly}

In Volume III of Tristram Shandy, Walter Shandy claims that in spite of the "worth" of his brother Toby's "honest ignorance," he will attempt to replace this "honest ignorance" with "knowledge" (TS, 3.18. 189). We have seen in Chapter Two of this study that Walter's worldly wisdom led to folly because, in Augustinian terms, he was obsessed with knowledge (speculation about temporal things) to the total exclusion of wisdom (contemplation of eternal things). Walter's conviction that "knowledge, like matter... was divisible in infinitum" (TS, 2.19.145) epitomizes his failure to maintain a proper balance between knowledge and wisdom which Augustine, among other writers that we have considered, deemed necessary in man's quest to achieve the wisdom of Christ.

Because of his "honest ignorance" and "common sense" (TS, 2.19.154) and because "of all men in the world, $\sqrt{\mathrm{he}} \mathrm{T}$ troubled his brain the least with abstruse thinking" (TS, 3.18.189), Toby, instead of Walter, is a fit receptacle for the wisdom of Christ. More than any of the novel's other characters, Toby resembles the unlearned "focl of nature." I Walter Kaiser reminds us that the "fool of nature" rejects "the Stoics. . the philosophers, the metaphysicians, the scientists, and the Schoolmen, because they employ anti-natural means 
to understand nature" (Kaiser, p. 95). Although Toby is not a wise fool in the sense that Tristram and Yorick are (nowhere in Tristram Shandy is Toby called a "fool"), the analogies between Toby and the unlearned "natural fool" identify Toby as an instrument of Christian wisdom. By exhibiting the gnomic wisdom of the "fool of nature," Toby, as we shall see, undercuts the foolish vanity of the worldly wise.

Two signs of Toby's fitness as a receptacle of divine wisdom are his child-like trust in God and his exemplary Christian charity. In the eyes of the Walter Shandys of this world, Toby's simple faith and charity are foolish because they lack the worldliness of human wisdom, but we have seen in Chapter One that simple faith, humility, and charity, instead of 'Walter's kind of worldly wisdom, enable man to become a worthy receptacle of divine wisdom. Traditionally singled out for praise by eighteenth- and nineteenth-century commentators, ${ }^{2}$ Toby's simple faith and charity have also been praised by recent critics. A.R. Towers, for example, eulogizes Toby as a "holy innocent, " 3 and John Stedmond calls him "a comic version of the saint" (Stedmond, p.81).

In the second section of this chapter, we shall see that while Trim shares Toby's function of undercutting the foolish wisdom of the novel's worldly wise men, he employs somewhat different means of executing this function. Representing Sterne's projection of the ideal preacher, Trim demonstrates that the "foolishness of preaching" (I Cor. 1.21) reveals wisdom far more rewarding than that reflected 
in the "enticing words of man's wisdom" (I Cor。2.4). In frustrating the false wisdom of the worldly wise, both Toby and Trim remind us that "God hath chosen the foolish things of the world to confound the wise; and . . the weak things of the world to confound the things which are mighty" (I Cor。1.27)。

The ability of the simple-minded Toby, whose "brain was like wet tinder" (TS, 3.39.236), to confound worldly wisdom is evinced when he subverts the speculative foundations of Walter's hypotheses. Walter's preoccupation with hypotheses about noses, indicated by his having "collected every book and treatise which had been systematically wrote upon noses" (TS, 3.34.224), provides a clear example of how Toby's "honest ignorance" and "common sense" expose the foolishness of worldly wisdom. Distraught because Erasmus' doctrine of noses (simply, that the nose makes the man) was "laid down . o with the utmost plainness [and7 without any . . speculative subtilty or ambidexterity of argumentation upon it" (TS, 3.37.229), Walter takes his penknife and literally tries to "scratch some better sense" into the humanist's sentence. When Walter ludicrously attempts to distort a sentence from one of Erasmus' Colloquia Familaria by actually altering a word on the printed page, Toby exposes the danger of man's foolish preoccupation with useless learning.

I've got within a single letter, brother Toby, cried my father, of Erasmus, his mystic meaning. --You are near 
enough, brother, replied my uncle, in all conscience. -Pshaw! cried my father, scratching on, --I might as well be seven miles off. --I've done it, =-said my father, snapping his fingers. --See, my dear brother Toby, how I have mended the sense. --But you have marr'd a word, replied my uncle Toby. - My father put on his spectacles, --bit his lip,-and tore out the leaf in a passion (TS, 3.37.230).

Functioning as an instrument of Sterne's satire upon useless learning, Toby exposes the foolish "extravagance of [Walter's] affliction" (TS, 3.30.217) --his obsession with "speculative subtilty or ambidexterity of argumentation," as exemplified in his ludicrous attempt to replace the literal meaning of Erasmus' doctrine of noses with a "mystic and allegoric" (IS, 3.37.299) meaning. Writing to Stephen Croft about the section of Tristram Shandy dealing with noses (Volume III, chapters 31-42), Sterne remarked:

- . the principal satire throughout that part is levelled at those learned blockheads who, in all ages have wasted their time and much learning upon points as foolish $\sqrt{i}$.e., as foolish as philosophical speculations upon noses (Letters, No. 70, p. 126).

In addition to functioning as an instrument of Sterne's satire upon useless learning, Toby exhibits his natural or gnomic wisdom by refusing to be taken in by his brother's claim that "learned men... don't write dialogues upon long noses for nothing" (TS, 3.37.229). The extent of Walter's obsession with philosophical speculations is indicated in his belief that "heaven had bestow'd the ability to speculate 7 upon man on purpose to investigate truth and fight for her on all sides" (TS, 3.37.229). While Walter foolishly attempts to ascertain "the mystic and the allegoric sense" (TS, 3.37.229) of Erasmus' doctrine of noses, Toby frustrates the attempt by reminding 
Walter that he has distorted Erasmus' literal meaning. By preventing Walter from marring a word, Toby has, in a small way, prevented his brother from further "crucifying" truth (TS, 9.32.644).

Besides undercutting the useless learning of Walter's speculative hypotheses, Toby exposes what Sterne considered some of the "abuses of religion" (Sermons, II, 179) practiced in the Catholic Church. 4 In his sermon "Penances," for example, Sterne lashes out at "such abuses of religion" as penances for making religion "consist in something which it ought not":

How such mockery became a part of religion at first, or upon what motives they were imagined to be services acceptable to God, is hard to give a better account of than what was hinted above; --namely, --that man of melancholy and morose tempers, conceiving the Deity to be like themselves, a gloomy, discontented and sorrowful being, --believed he delighted, as they did, in splenetic and mortifying actions (Sermons, II, 179). 5

The butt of Sterne's anti-Catholic satire in Tristram Shandy is the Papist Dr. Slop, whose religion is the object of both Trim's and Toby's satiric thrusts. During Trim's reading of Yorick's sermon upon abuses of conscience in Volume II, Dr. Slop launches into an apology for the Catholic doctrine of the seven sacraments. The brief conversation between Toby and Slop on the subject of the seven sacraments shows how Sterne utilizes Toby to expose what he, as an Anglican priest, considered abuses in religion:

Pray how many have you in all, said my uncle Toby, --for I always forget? --Seven, answered Dr. Slop. --Humph! --said my uncle Toby; tho' not accented as a note of acquiescence, --but as an interjection of . . . surprise . . Humph! replied my uncle Toby. Dr. Slop, who had an ear, understood my uncle Toby as well as if he had wrote a whole volume against the seven sacraments (TS, 2.17.129). 
Sterne's utilization of Toby to expose what Sterne considered the artificiality of Catholic doctrine is further exemplified when Toby challenges Slop's assertion about the value of the sacrament of confession. "Amongst us í.e., Roman Catholics], a man's conscience could not possibly continue to be7 long blinded," Dr. Slop asserts, for "'three times in a year, at least, he must go to confession.' 'Will that restore it to sight?' quoth my uncle Toby" (IS, 2.17.130). The effectiveness of Toby's rhetorical question illustrates the extent to which "a plain man, with nothing but common sense" (IS, 2.19.154) can undercut the false learning espoused by such worldly wise men as Walter Shandy and Dr. Slop.

Both Toby's function of exposing the folly of worldly wisdom and the efficacy of his simple faith in God become more evident in the sequence of scenes where Walter relates his theory of Christian names-that "good or bad" names determine men's characters and conducts--and his hypothesis that man can withstand adversity by relying totally on his own resources. Although Walter laments the crushing of his son's nose at birth as further proof of the "persecution against him" (TS, 4.19.297), he draws comfort from the "one cast of the dye left for $\overline{\text { his }}$ child" (TS, 4.19.298) --fulfilling his theory of Christian names by naming his son "Trismegistus." Referring to the comfort afforded by his "opinion of Christian names" (TS, 4.8.279), Walter says to Toby: "'tis wonderful by what hidden resources the mind is enabled to stand it out, and bear itself up, as it does against the impositions laid upon our nature" (TS, 4.7.277). Exhibiting the simple eloquence of 
the wise fool, Toby reminds his brother that the truly wise man relies upon God to assist him in meeting life's exigencies:

"Tis by the assistance of Almighty God, cried my uncle Toby, looking up, and pressing the palms of his hands close together--'tis not from our own strength, brother Shandy--a sentinel in a wooden centry-box, might as well pretend to stand it out against a detachment of fifty men, --we are upheld by the grace and the assistance of the best of Beings (TS, 4.7.277-78).

From the point of view of worldly wisdom, represented here by Walter Shandy, Toby's unquestioning faith in God's grace is simple-minded and characteristic of his "honest ignorance" (TS, 3.18.189). Walter's condescending attitude toward his brother's lack of "knowledge" (TS, 3.18.189) is seen in his comment upon Toby's trust in divine providence: "That $\sqrt{i} . e .$, trusting in divine providence 7 is cutting the knot ... instead of untying it. --But give me leave to lead you, brother Toby, a little deeper into this mystery" (TS, 4.7.278).

Unwilling to accept the traditional Christian view which Toby articulates, that the Lord is man's shepherd in times of distress, Walter characteristically tangles himself up in a web of distorted speculations about human nature. Describing man as a "most curious vehicle," Walter asserts that man is able to withstand his "rugged journey" through life only because of "a secret spring within him" (IS, 4.8.278). Far from being the fool that walter thinks he is, Toby undercuts his brother's unnaturally contrived assertions about the "mystery" of man's "secret spring" by identifying man's "secret spring" as "Religion" (TS, 4.8.278). Walter's reaction to Toby's faith in religion reveals the degree to which Walter's speculative 
hypotheses have prevented him from sharing his brother's fitness to receive the wisdom of Christ:

Will that set my child's nose on? cried my father, letting go his finger, and striking one hand against the other--It makes every thing straight for us, answered my uncle Toby-Figuratively speaking, dear Toby, it may, for aught I know, said my father; but the spring I am speaking of, is that great and elastic power within us of counterbalancing evil, which like a secret spring in a well-ordered machine, though it can't prevent the shock--at least it imposes upon our sense of it (TS, 4.8.279).

Several passages from two of Sterne's sermons illuminate the superiority of Toby's natural wisdom to Walter's acquired learning by showing that Toby is a spokesman for the Christian teachings expressed in The Sermons of Mr. Yorick. In "Trust in God," for example, Yorick recalls Paul's exhortation to the Corinthians "never to depend on any worldly trust, but only on God" (Sermons, II, 153), and concludes his sermon by encouraging his flock to "learn this great lesson in the text, in all thy exigencies and distresses, --to trust GOD" (Sermons, II, 156). As seen in a passage from "On Enthusiasm," Toby's trust in God and his recognition of the divine source of human fortitude echo Yorick's words in the Sermons:

However firmly we may think we stand--the best of us are but upheld, and graciously kept upright; and whenever this divine assistance is withdrawn, --or suspended, --all history, especially the sacred, is full of melancholy instances of what man is, when God leaves him to himself, --that he is even a thing of nought (Sermons, II, 192).

The discussion between the Shandy brothers about the source of man's ability to withstand adversity dramatizes the distinction between the foolishness of Walter's "knowledge" and the wisdom of 
Toby's "honest ignorance." Significantly, Toby's reminder to Walter that man is "upheld by the grace and the assistance of the best of Beings" (TS, 4.7.278) echoes Yorick's warning in his sermon "Trust in God." "Without some certain aid within us to bear us up," the preacher begins his sermon, "so tender a frame as ours, would be but ill fitted to encounter what generally befals it in this rugged journey" (Sermons, II, 147). It is precisely because Toby "troubled his brain the least with abstruse thinking" (TS, 3.18.189) that he is such an effective instrument for imparting the Christian wisdom contained in Sterne's sermon "Trust in God."

Even though Walter recognizes the existence of a "secret spring" within man which enables him to survive his "rugged journey" through life (TS, 4.8.278), his short-sighted worldly wisdom prevents him from perceiving the role of divine providence in assisting man in his voyage through life. Not only does Walter's vain worldly wisdom blind him to the workings of God's hand in providing man with a built-in "secret spring"; it also prevents him from following Toby's advice to seek "the assistance of the best of Beings" (TS, 4.7.278) when man's inner "secret spring" runs afoul of life's exigencies. Walter's foolish blindness to Christian wisdom becomes more evident in light of Sterne's expansion upon the theme of divine trust in his sermon "Trust in God." Indicative of his greater wisdom, the preacher Yorick in "Trust in God" sees through the apparent fortuitism of man's inner spring. Unlike Walter, Yorick perceives God's design in providing man with an inner power which operates "like a secret spring in a well- 
contrived machine" (Sermons, II, 148). ${ }^{6}$ The failure of Walter's worldly wisdom to understand the workings of this "secret spring" is revealed when Yorick not only identifies "the principle of self-love" as the force generating man's secret spring" (Sermons, II, 147), but also assesses the limitations of this generating force. Describing selflove as "one of the most deceitful of human passions," Yorick argues that it "too often disappoints in the end" (Sermons, II, 147), by inclin/ing] us to think better of ourselves, and conditions, than there is ground for" (Sermons, II, 149). By a process of induction, Yorick arrives at the same conclusion reached by Toby's intuitive gnomic wisdom--that "Religion" is ultimately man's only fool-proof "secret spring." Since "we still find a necessity of calling something to aid this principle" of self-love, Yorick argues, "reason and religion are called in at length, and join with nature in exhorting us to hope; -but to hope in God, in whose hands are the issues of life and death" (Sermons, II, 149). In light of the similarity between Yorick's advice to his congregation and Toby's advice to Walter, then, Walter's foolish rejection of God's assistance becomes more blameworthy, while Toby's function as an instrument for imparting Christian wisdom becomes more evident.

The short-sightedness of Walter's worldly wisdom is epitomized in his attempt to "counteract and undo" the evil of his son's crushed nose by naming him Trismegistus:

But alas! continued my father, as the greatest evil has befallen him--I must counteract and undo it with the greatest good. 
He shall be christened Trismegistus, brother.

I wish it may answer--replied my uncle Toby, rising up (TS, 4.8.279).

The folly of Walter's trust in his "opinion of Christian names" (TS, 4.8.279), and the wisdom of Toby's skeptical view of worldly wise hypotheses, become more evident in light of Walter's reasons for relying on a name to undo "evil." Because "there never was a great or heroic action performed since the world began by one called Tristram" (TS, 4.18.295), Walter believes that "there was a strange kind of magick bias which good or bad names . . irresistibly impress'd upon our characters and conduct" (TS, 1.19.150). For Walter, Trismegistus is the most fitting name for his son because he was "the greatest . . of all earthly beings . . the greatest king--the greatest lawgiver--[and] the greatest philosopher" (TS, 4.11.283-84). Typifying his interest in religion, Toby reminds Walter that Trismegistus was also "the greatest priest" (TS, 4.11.284), thereby pointing to Walter's indifference to anything of an other-worldly nature. Walter's comment upon Toby's reminder of Trismegistus' priestly fame-"in course" (TS, 4.11.284) ${ }^{7}$--confirms Walter's indifference to religion in the order of things.

Compounding Walter's indifference to religion and religious values is his selection of Trismegistus for his son's name in spite of the name's pejorative connotations in patristic literature. The "Greek name of Thoth, the Egyptian god of wisdom" (Work, ed., TS, p. 279, n。2), Trismegistus (also called Hermes) is attacked by several Church Fathers as a symbol of worldly folly. ${ }^{8}$ In The City of God, for example, St. Augustine devotes two chapters to denouncing 
Trismegistus as a fool in the eyes of God. While pointing out that Trismegistus revealed the error of his Egyptian forefathers in invent[ing7 the art of making gods" (The City of God, 8.24.129), 9 Augustine condemns Trismegistus for bewailing the future destruction of the pagan deities:

- . he bears witness to Christianity by a kind of mournful prophecy. Now it was with reference to such that the apostle said, that "knowing God, they glorified Him not as God, neither were thankful, but became vain in their imaginations, and their foolish heart was darkened; professing themselves to be wise, they became fools" . . For Hermes makes many such statements agreeable to the truth concerning the one true God who fashioned this world. And I know not how he has become so bewildered by that darkening of the heart as to stumble into the expression of a desire that men should always continue in subjection to those gods which he confesses to be made by men, and to bewail their future removal (The City of God, 8.23.127-28).

It would seem unlikely that in the systematic pursuit of his opinion of Christian names, Walter would be ignorant of Trismegistus' reputation as a symbol of worldly folly in patristic literature. Tristram reminds us that Walter, in his opinion "of the influence of Christian names... was serious; --he was all uniformity; --he was systematical, and, like all systematick reasoners, he would move both heaven and earth, and twist and torture every thing in nature to support his hypothesis" (TS, 1.19.153). In addition, Tristram points out that his father "would lose all kind of patience whenever he saw people. . who should have known better, --as careless and as indifferent about the name they imposed upon their child, --or more so, than in the choice of Ponto or Cupid for their puppy dog" (TS, 1.19. 53.54). It would seem more in keeping with Walter's obsession with worldliness to assume, then, that he would deliberately choose the 
pagan god of worldly wisdom as the name of the son he was grooming to succeed him as philosopher par excellence of Shandy Hall.

Just as walter foolishly stressed worldly rather than religious qualities in his choice of Tristram's name, so he did in his choice of qualities for Tristram's tutor. The discussion about desirable qualities in Tristram's tutor serves as another example of the superiority of Toby's natural wisdom to the foolishness of Walter's worldly wisdom. For Walter, Tristram's tutor must be "prudent, attentive to business, vigilant, acute, argute, inventive, quick in resolving doubts and speculative questions .. wise and judicious, and learned" (TS, 6.5 . 415). Once again, Toby exhibits his gnomic wisdom by siding with the wise fool, Yorick, to expose Walter's foolish obsession with worldly wisdom: "And why not humble, and moderate, and gentle tempered, and good? said Yorick: --And why not, cried my uncle Toby, free and generous, and bountiful, and brave?" (TS, 6.5.415) In commenting upon Toby's sense of humanity, John Stedmond reminds us that "Toby, 。. like the traditional 'Wise' fools, is on the side of nature against human attempts to institutionalize man's instincts" (Stedmond, p.92).

Walter's preoccupation with the muddled world of his hypotheses, with their emphasis on material, this-worldly gains, prevents him from realizing the folly of his faith in all abstract systems, epitomized by hi.s hypothesis of Christian names. Like his Tristra-poedia, Walter's theory of Christian names is foolish also in its irrelevance to the reality of human experience. Whereas the wise fool Tristram exposes the foolish wisdom of his father's educational system, the 
unlearned Toby exposes the folly of Walter's obsession with naming his son Trismegistus. "For my own part," Toby tells Trim, "I can see little or no difference betwixt my nephew's being called Tristram or Trismegistus" (IS, 4.18.294). It is fitting that Toby's unlearned counterpart Trim aids his master in puncturing Walter's theory of Christian names:

Bless your honour! cried Trim, advancing three steps as he spoke, does a man think of his christian name when he goes upon the attack? --Or when he stands in the trench, Trim? cried my uncle Toby, looking firm--Or when he enters a breach? said Trim, pushing in between two chairs --Or forces the lines? cried my uncle, rising up, and pushing his crutch like a pike --Or facing a platoon, cried Trim, presenting his stick like a fire-lock --Or when he marches up the glacis, cried my uncle Toby, looking warm and setting his foot upon his stool (TS, 4.18 .295 ).

Tristram's successful narration of his life and opinions, in spite of his name, disproves Walter's hypothesis about the "magic bies which good or bad names irresistably [sic] impress upon our characters and conducts" (TS, 4.8.279). Tristram's success, moreover, testifies to Toby's wisdom in trusting in God, rather than man's irrelevant speculative systems, as a means of confronting IIfe's exigencies. Typical of the failure of Walter's worldly wise schemes to stem the overwhelming tide of adversity resulting from his son's misfortunes is his "lamentation" after his son's baptism (TS, 4.19.296-98). Lamenting the subversion of his "last cast" for his son's success-naming him Trismegistus--Walter cries out despairingly: "Tristram! Tristram! Tristram! (TS, 4.19.298) Toby's advice to "send for Mr Yorick" (TS, 4.19.298) once again illustrates his trust in a different kind of wisdom which, Sterne seems to suggest, is not as foolish as 
it may appear to those like walter, who place all their trust in worldly wisdom.

The "wisdom" of Walter's attempt to counteract evil by relying upon his hypotheses becomes more foolish when it is seen that his deliverance from one misfortune results ironically from the arrival of another. Soon after the "learned divines" at the visitation dinner reject Walter's plea to annul Tristram's baptism, Walter receives a legacy of a thousand pounds from Tristram's aunt, Dinah. Walter's problem about whether to utilize the money on Bobby's grand tour of the continent or on cultivating the unused common next to the Shandy estate is an "evil" from which walter is delivered only by the news of Bobby's death. Tristram's comment upon his father's delivery from this "evil" necessity of making a decision suggests the folly of man's attempt to "undo" evil without God's help:

My father had certainly sunk under this evil, as certainly as he had done under that of my CHRISTIAN NAME-had he not been rescued out of it as he was out of that, by a fresh evil--the misfortune of my brother Bobby's death (TS, 4.31 .336$)$.

Walter's attempts to combat Iife's adversities with hypotheses, then, prove foolish in view of man's finite capabilities and the characteristic irrelevance of hypotheses to human experience. Tristram's observation that "the life of man... is... to shift from side to side--from sorrow to sorrow--to button up one cause of vexation! --and unbutton another!" (TS, 4.31.336) is a fitting testimony to the wisdom of Toby's reliance on God's providence and the foolishness of Walter's total reliance on man's works. 
Thus far, we have seen that Toby's simple trust in God and his skeptical attitude toward both Walter's speculative hypotheses and Dr. Slop's attempts to impose abstract schemes upon religion are signs that he is a receptacle of divine wisdom. Perhaps the most evident sign of Toby's function as an instrument of Christian wisdom is his exemplary charity and his all-suffering compassion for his fellow man. We recall Thomas à Kempis' teaching that "to judge and to think well and blessedly of others, is a sign and a token of great wisdom" (Imitatio, 1.2.6.). Toby's sense of charity and compassion is evinced in his conversation with Dr. Slop at the time of Tristram's birth. When Dr. Slop invokes "'all the angels and archangels, principalities and powers, and all the heavenly armies'" (TS, 3.11.173) to curse Obadiah, the Shandy servant who had knotted his instrument bag, Toby exclaims: "Our armies swore terrible in Flanders, . . but nothing to this. --For my own part, I could not have a heart to curse my dog so" (TS, 3.11.175). After slop has completed reading the excommunication curse, Toby, by showing compassion even for the devil, illustrates the unrestricted kind of charity which has earned him the praise of Hazlitt, among others, who eulogized him as "one of the finest compliments ever paid to human nature": 10

I declare, . . my heart would not let me curse the devil himself with so much bitterness. --He is the father of curses, replied Dr. Slop. --So am not I, replied my uncle. - But he is cursed, and dann'd already, to all eternity, --replied Dr. Slop.

I am sorry for it, quoth my uncle Toby (TS, 3.11.179).

Toby's charity and philanthropy become most evident in his compassionate care of the dying Le Fever, and in his paternal kindness 
in raising Le Fever's orphaned son. Even though Toby's attempts to save Le Fever are in vain, his compassionate philanthropy earns Tristram's esteem. "There was a frankness in my uncle Toby," Tristram writes of his uncle's offers of kindness to Le Fever,

. . which let you at once into his soul, and shewed you the goodness of his nature; to this, there was something in his looks, and voice, and manner, superadded, which eternally beckoned to the unfortunate to come and take shelter under him (TS, 6.10.426)!1

It is significant that previous commentators have singled out Toby's conduct toward Le Fever as exemplary of man's ideal behavior towards his fellow man. In 1777, an anonymous essayist wrote that in the story of Le Fever Sterne "has taught us, that the human heart is capable of the greatest improvement; and that nature never feels herself more noble and exalted, than in the exercise of benevolence and humanity。" 12 William Hazlitt, one of Sterne's most ardent admirers, acclaimed the story of Le Fever as "perhaps the finest in the English language." 13

Toby's spontaneous offers of assistance to Le Fever, which included not only the use of his house and provisions, but also Trim's services as a "nurse" and his own services as a "servant" (TS, 6.10. 426), illustrate the ideal of Christian charity expressed in many of Sterne's sermons. 14 As Sterne points out in "Philanthropy Recommended," a sermon based on the story of the Good Samaritan, Christ's command to love one's neighbor as oneself is a divine injunction for universal charity. Reminding his congregation that Christ told the story of the Good Samaritan when asked, "who is my neighbor?" (Luke, 
10.29), Sterne said: "Our blessed SAVIOUR, to rectify any partial and pernicious mistake in this matter...place d at once this duty of the love of thy neighbor upon its true bottom of philanthropy and universal kindness (Sermons, I, 26). 15

For Sterne, who once feared that "there can be little left to be said upon the subject of Charity, which has not been often thought, and much better expressed by many who have gone before" (Sermons, I, $51),{ }^{16}$ charity was as much a natural impulse as a Christian duty. Nature has "deeply .. sown the seeds of compassion in every man's breast" (Sermons, I, 64), Sterne asserts in his "Charity Sermon," "Elijah and the Widow," while in "Vindication of Human Nature," he reminds his flock that

-. God made man in his own image, --not surely in the sensitive and corporeal part of him, that could bear no resemblance with a pure and infinite spirit, --but what resemblance he bore was undoubtedly in the moral rectitude, and the kind and benevolent affectations of his nature (Sermons, I, 82).

Toby's unselfish and spontaneous offer to provide for all of Le Fever's needs and his exemplary upbringing of Le Fever's son ${ }^{17}$ dramatize Sterne's description of man's natural benevolence in his sermon "Philanthropy":

In benevolent natures the impulse to pity is so sudden - that you would think the will was scarce concerned, and that the mind was altogether passive in the sympathy which her own goodness has excited. The truth is, --the soul is generally in such cases so busily taken up and wholly engrossed by the object of pity, that she does not attend to her own operations, or take leisure to examine the principles upon which she acts (Sermons, I, 32).

The London Times reviewer, Desmond MacCarthy, was hardly exaggerating 
when he remarked that the "Christianity Sterne preached was at bottom that of Uncle Toby." 18

Toby's benevolence and charity would hardly be judged "foolish" by an age which was exhibiting a renewed "sensitiveness to human need and was developing fresh instruments for dealing with it."19 Henry Fielding voiced this renewed "sensitiveness" in 1749 when he proclaimed that charity "is the very characteristic virtue at this time. I believe that we may challenge the whole world to parallel the examples which we have of late given of this sensible, this noble, this Christian virtue. ${ }^{20}$ However, in view of the worldly wisdom that Robert South described as "a wisdom which7 lies in practice, and goes commonly by the name of policy" (South, p. 335), Toby's universal charity would be considered foolish for not restricting itself to "the rich or potent, from whom a man may receive a further advantage" (South, p. 346). Tristram's "tribute" to his uncle's "goodness" (TS, 3.32.224) suggests that, for Sterne, wisdom manifests itself neither in "the knowledge of man and business... nor in mak [ing] use of opportunity whilst [one] has it" (Sermons, II, 54-5), but in an allsuffering compassion:

Thou envied'st no man's comforts, --insulted'st no man's opinion. --Thou blackened'st no man's character, --devoured'st no man's bread: gently with faithful Trim behind thee, didst thou gamble round the little circle of thy pleasures, jostling no creature in thy way; --for each one's sorrows, thou hadst a tear, --for each man's need, thou hadst a shilling (TS, 3.32.224).

Two more examples of Toby's unrestricted charity toward and his compassion for his fellow man will suffice to show the degree of his Christian wisdom. Exemplifying the orthodox Anglican doctrine 
that "charity is . . to love every man, good and evil, friend and foe," 21 Toby admonished Trim for attacking clerical hypocrjsy ("God only knows who is a hypocrite, and who is not" $)^{22}$ and forgives walter for "wish/ing 7 the whole science of fortifications, with all its inventors, at the devil" (TS, 2.12.113). Tristram reports that after Walter virulently attacked Toby's hobby-horse Toby looked at his brother "with a countenance spread over with so much good nature; --so placid; --so fraternal . . it penetrated [Walter] to his heart":

He rose up hastily from his chair, and seizing hold of both my uncle Toby's hands as he spoke: --Brother Toby, said he, --I beg thy pardon; --forgive, I pray thee, this rash humour which my mother gave me。--My dear, dear brother, answer'd my uncle Toby, rising up by my father's help, say no more about it; --you are heartily welcome, had it been ten times as much, brother (TS, $2.12 .115)$.

In view of Hammond's assertion that "there is not a great deal of evidence to show that [Sterne] was particularly concerned with the doctrines peculiar to or distinctive of the Christian religion" (Hammond, p. 92), it is necessary to point out that Sterne's plea for Christian charity in the Sermons, and his projection of Toby as the personification of Christian charity in Tristram Shandy, underscore the orthodox Anglican teaching that a truly charitable man must extend his benevolence to all, and not just to a few. Emblematic of the type of unselfish charity which we have seen Sterne advocate in the Sermons are his remarks that "true charity is always unwilling to find excuses," and that "in generous spirits, compassion is sometimes more than a balance for self-preservation" (Sermons, I, 55). 
In light of the emphasis on charity in The Sermons of Mr. Yorick, Sterne would hardly disagree with the anonymous author of "Homily of Almsdeeds" for castigating "the manner of wise worldly men among us, -. Who7, if they know a man of meaner estate than themselves to be in favour with the prince or any other noble man..., such a one they will be glad to benefit and pleasure."123 As we have seen, Sterne would also support Robert South's rejection of the calculated practice of "showing kindness ... only to the rich or potent, from whom a man may receive a further advantage" (South, p. 336). In his sermon on the wisdom of Christian folly, South reminds his listeners that the calculated practice of bestowing kindness upon a select few exemplifies one of the four "principles" by which "policy or wisdom governs its actions" (South, p. 346). In his charitableness towards both friend and foe, then, Toby personifies the ideal of Christian charity as found in the sermons of Sterne and other orthodox Anglican divines.

With regard to his liberal practice of Christian charity, Toby may be called a "fool" in so far as he guilelessly practices what the gospels preach. Toby's kind of "folly" exemplifies what Robert South praised as the "folly of being sincere, and without guile; without traps and snares in our converse" (South, p. 37I). "Let us not blush to be found guilty to all these follies, "South continues, "rather than be expert in that kind of wisdom [I.e., wordly wisdom, that God himself . . has pronounced to be earthly, sensual, [and7 devilish" (South, p. 371). 
Although it can never be proved that Sterne modeled the character of Toby upon the Biblical character of Tobias, in the apocryphal Book of Tobit, it is interesting to note an analogy between Tristram's uncle and his Biblical counterpart. Whereas Toby is the model of charity in Tristram Shandy, King Tobias grooms his son of the same name to be charitable:

Give alms of thy substance; and when thou givest alms, let not thine eye be envious, neither turn thy face from any poor, and the face of God shall not be turned away from thee. 24

The analogy to the apocryphal story is instructive. Tristram's uncle is like King Tobias in that both men set examples of charity for their younger relatives: King Tobias for his son, and Toby, in his refusal to "retaliate upon a fly," for his nephew Tristram. In commenting upon his uncle's refusal to kill a bothersome fly, an event which took place when Tristram was only ten, Tristram observes: "I owe one half of my philanthropy to that one accidental impression" (TS, 2.12.114). Tristram's uncle is also like the son of King Tobias: while the young prince literally brings the gift of sight to his father the King, the unlearned and benevolent Toby symbolically brings the gift of sight (Christian wisdom) to Shandy Hall, thereby revealing the distorted vision of this world's foolish wisdom. 
Like Toby, Corporal Trim also demonstrates the truth of Paul's reminder that "God hath chosen the foolish things of the world to confound the wise; and ... the weak things of the world to confound the things which are "mighty" ( I Cor。 1.27). More than just a "mechanical man" 25 or a "puppet, moved by unseen strings," 26 Trim, like his master Toby, demonstrates the mid-eighteenth-century Anglican conviction, expressed by Bishop Butler, that Christianity was essentially "a plain and obvious thing" that could be understood by "common men." 27 In his dramatic reading of Yorick's sermon at the end of Volume II of Tristram Shandy and in his own eloquent funeral oration upon Bobby's death, moreover, Trim becomes not just "a mask for Tristram, ${ }^{28}$ but Sterne's projection of the ideal preacher. His funeral oration, in particular, dramatizes the conviction of the praisers of folly from the time of St. Paul--that the words of wisdom are often uttered by those humble and unlearned men whom the worldly wise often consider to be fools.

Trim, as I hope to show, is a "fool" in much the same way that Toby is. Unlearned and unsophisticated in the eyes of the world, Trim, like his master, is a receptacle of divine wisdom. Whereas Toby manifests his wise folly primarily in his charity and compassion, Trim manifests his wise folly primarily in his speech, particularly in his extemporaneous funeral oration upon Bobby's death. Similar to the speech of the "medieval Idiot" which "for all its ignorance, at times managed to pierce through the veils of convention and propriety to the 
profound simplicity of Christlike truth, "19 Trim's simple speech contains a high degree of Christian wisdom lacking in the speech of the worldly wise.

Trim's Christian wisdom is evinced in his ability to undercut the foolishness of worldly wisdom as seen when he gives Walter a lesson in what Yorick calls "practical divinity" (TS, 5.28.387). During a discussion between Walter and Yorick concerning a child's duty to his parents, Toby informs his brother that Trim could "repeat every word of the Catechism7 by heart" (TS, 5.32.392). Although Walter did not wish his speculations about "the natural relation between a father and his child" to be "interrupted with Trim's saying his Catechism" (TS, 5.31.391;32.392), Toby leads Trim through a religious exercise of repeating the Ten Commandments. After Trim has repeated the first five commandments to Toby's satisfaction, Walter exclaims:

--SCIENCES MAY BE LEARNED BY ROTE, BUT WISDOM NOT. Yorick thought my father inspired. --I will enter into obligations this moment, said my father, to lay out all my aunt Dinah's legacy, in charitable uses (of which, by the bye, my father had no high opinion) if the corporal has any one determinate idea annexed to any one word he has repeated. --Prythee, Trim, quoth my father, turning round to him, --What do'st thou mean, by "honouring thy father and mother?" (TS, 5.32.393)

Although Walter "abuses Trim with straight Lockean cant for his lack of determinate ideas when the corporal recites the Ten Commandmerts, "30 Trim nevertheless understands the divine injunction to honor his parents more satisfactorily than Walter, whose only concern with Trim's familiarity with the commandment is to expose him as a mechanical puppet. When Trim tells Yorick that he fulfilled the divine injunction 
by allowing his parents "three halfpence a day out of my pay, when they grew old" (TS, 5.32.393), Yorick points out that Trim is not the kind of fool Walter thinks he is:

Then, Trim, said Yorick, springing out of his chair, and taking the corporal by the hand, thou art the best commentator upon that part of the Decalogue; and I honour thee more for it, Corporal Trim, than if thou hadst had a hand in the Talmud itself (TS, 5.32.393).

Unlike Walter, whose concern with determinate ideas about religion reveals him as the wrong kind of fool, Trim exhibits the natural wisdom of the common man by embodying the "practical divinity" which Yorick had praised earlier:

I wish there was not a polemic divine, said Yorick, in the kingdom; --one ounce of practical divinity--is worth a painted ship load of all their reverences have imported these fifty years (TS, 5.28.387).

Trim's function as an instrument of divine wisdom becomes more evident in his dramatic reading of Yorick's sermon "The Abuses of Conscience, Considered" to the Shandy brothers and Dr. Slop. Martin Price has remarked that Trim's reading of Yorick's sermon manifests a "power of sympathy $\sqrt{\text { which }}$ ] breaks through all the forms of language and achieves a terrifying immediacy" (Price, p. 323). When Trim comes to the passage in the sermon dealing with the Inquisition, he interjects a bitter denunciation of the institution which has kept his brother Tom prisoner for fourteen years:

"Behold Religion, with Mercy and Justice chained down under her feet, -there sitting ghastly upon a black tribunal, propp'd up with racks and instruments of torment. Hark! -hark! what a piteous groan!" (Here Trim's face turned as pale as ashes.) "See the melancholy wretch who utter'd it," -- (Here the tears began to trickle down) "just brought forth 
to undergo the anguish of a mock trial... (D--n them all, quoth Trim, his colour returning into his face as red as blood.) -- "Behold this helpless victim delivered up to his tormentors...."-- (Oh! 'tis my brother, cried poor Trim in a most passionate exclamation, dropping the sermon upon the ground, and clapping his hands together) (TS, 2.17.138).

After praising Yorick's sermon for its "dramatic" quality (TS, 2.17. 141), ${ }^{31}$ Walter praises Trim's emotional delivery. When Trim apologizes to Walter that his "full heart" prevented him from reading the sermon more effectively, Walter says:

That was the very reason, Trim.. . which has made thee read the sermon as well as thou hast done; and if the clergy of our church . . . would take part in what they deliver, as deeply as this poor fellow has done, --as their compositions are fine: (I deny it, quoth Dr. Slop) --I maintain it, that the eloquence of our pulpits, with such subjects to inflame it, --would be a model for the whole world: --But alas! -. and I own it, Sir, with sorrow, that, like the French politicians in this respect, what they gain in the cabinet they lose in the field (TS, 2.17.141).

Through Trim's emotional reading of Yorick's sermon, Sterme projects his image of the ideal preacher as being naturally versed in dramatic arts. When Steme remarks that "lessons of wisdom have never such power over us, as when they are wrought into the heart, through the groundwork of a story which engages the passions" ("The Prodigal Son, "Sermons, I, 227), he expresses a conviction similar to that contained in Stultitia's observation that men pay more attention to clowns and jesters than to sermons. In a letter to his wife, Sterne praises a well-known Parisian preacher for his ability to captivate his congregation:

I have been three mornings together to hear a celebrated pulpit orator near me, one Pere Clement, who delights me much - his matter solid, and to the purpose; his manner, more than theatrical, and greater, both in his action and delivery, 
than Madame Clarion, who, you must know, is the Garrick of the stage here; he has infinite variety, and keeps up the attention by it wonderfully; his pulpit . . . in short, 'tis a stage, and the variety of his tones would make you imagine there were no less than five or six actors on it together (Letters, No. 84, pp.154-55).

Sterne's projection of Trim as the ideal preacher, wise in the ways of the heart, becomes more apparent in Trim's funeral sermon to the Shandy servants on the occasion of Bobby Shandy's death. Trim begins his funeral sermon by dramatizing man's mortality:

"Are we not here now;" --continued the corporal, "and are we not" -- (dropping his hat plumb upon the ground--and pausing, before he pronounced the word) --"gone! in a moment?" The descent of the hat was as if a heavy lump of clay had been kneaded into the crown of it. --Nothing could have expressed the sentiment of mortality, of which it was the type and fore-runner, like it (TS, 5.8.362).

By using a gesture, Trim, whom Tristram describes as "no mean actor" (TS, 3.23.207), exhibits the ability of the wise fool to penetrate the conventions of language and communicate directly to the heart.

In contrast to Trim's genuine expression of sorrow for the death of Bobby is the unnaturalness of Walter's philosophical oration upon death. Although Walter "was by nature eloquent," his eloquence, Tristram observes, was ironically "his weakness--for he was hourly a dupe to it" (TS, 5.3.352). Instead of lamenting his son's death, Walter embarks upon what Tristram calls the "entire set" of "fine saying $\sqrt{\text { s }}$ " which "Philosophy has.. for Death" (TS, 5.3.353). An excerpt from Walter's oration will suffice to show the unnaturalness of his reaction to his son's death: 
"There is not such great odds, brother Toby, betwixt good and evil, as the world imagines"--(this way of setting off, by the bye, was not likely to cure my uncle Toby's suspicions.)

--"Labor, sorrow, grief, sickness, want, and woe, are the sauces of life." --Much good may it do them--said my uncle Toby to himself.--

"My son is dead! --so much the better; --'tis a shame in such a tempest to have but one anchor" (TS, 5.3.355).

In view of Tristram's account that Walter had become so enmeshed in his philosophical consolations that "he had absolutely forgot my brother Bobby" (TS, 5.3.356), few would disagree with Ernest Tuveson's observation that Trim's "simple, perfectly managed gesture of dropping his hat. . produc [ed] a much greater effect on the heart than did Mr. Shandy's rhetorical philosophizing" (Tuveson, p. 269).

As Trim continues his funeral oration, it becomes increasingly evident that his simple appeal to the heart exposes the folly of Walter's worldly-wise philosophical "sayings." Before further considering Trim's funeral oration, however, we should emphasize Sterne's conviction that the method of the actor in the pulpit was the most direct way of appealing to the heart. Although Sterne once claimed that he did not "know .. . whether the remark is to our honour or otherwise, that lessons of wisdom have never such power over us, as when they are wrought into the heart" (Sermons, I, 227), he seems to agree with Stultitia's observation that men will listen to those who appeal to the "heart" rather than the "head." To see Trim as Sterne's personification of a pulpit actor is to understand how Trim functions as an instrument of divine wisdom and to understand Sterne's concept of preaching. 
Sterne reveals the essence of his concept of preaching--a direct, emotional appeal to the heart--in a letter written to George Whatley concerning Sterne's promise to deliver a "charity sermon" on April 5, 1761, at the Foundling Hospital in London:

- . I will give you a short sermon, and flap you in my turn: --preaching (you must know) is a theological flap upon the heart, as the dunning for a promise is a political flap upon the memory: --both the one and the other is useless where men have wit enough to be honest (Letters, No. $74, p .134), 32$

Lansing Hammond has noted that "Sterne's 'definition' of preaching was doubtless suggested to him by a passage in the third book of Swift's Gulliver's Travels (chap. ii)" (Hammond, p. 100, n. 4). While on his travels in Book III, Gulliver observes that one of the curious customs of the Laputians is their employment of servants to "flap" them with bladders which are attached "like a Flail to the End of a short Stick" (Travels, 3.2.132).33 The function of these "flappers," Gulliver learns, is to stimulate communication between the Laputians whose "Minds -. are so taken up with intense Speculations, that they neither can speak, or attend to the Discourses of others, without being rouzed by some external Taction upon the Organs of Speech and Hearing" (Travels, $3.2 .132)$.

In Tristram Shandy, Trim theologically "flaps" worldly wise men like Walter Shandy by appealing directly to their hearts in order to remind them that man's "conversation is in heaven" (Phil.3.20). 34 Trim functions as an instrument of divine wisdom by rejecting philosophical arguments in favor of the simple language of the Scriptures. 
In order to remind his listeners of their mortality, for example, he utilizes a Biblical metaphor found in Jeremiah 2.27 and 3.9: 35

I said, "we were not stocks and stones" --'tis very well.

I should have added, nor are we angels, I wish we were,

--but men cloathed with bodies, and governed by our

imaginations (TS, 5.7.361).

To Tristram, Trim's description of man as neither a senseless image

nor an angel warrants the reader's careful attention:

Now as I perceive plainly, that the preservation of our constitution in church and state, --and possibly the preservation of the whole world . . may in time to come depend greatly upon the right understanding of this stroke of the corporal's eloquence--I do demand your attention (TS, 5.7.361).

The essence of Sterne's distinction between the "simple" eloquence of preaching the gospels and the "false" eloquence of flaunting man's wit is seen in Yorick's criticism of the sermon he had intended to deliver at the church visitation dinners:

To preach, to show the extent of our reading or the subtleties of our wit--to parade it in the eyes of the vulgar with the beggarly accounts of a little learning, tinseled over with a few words which glitter, but convey little light and less warmth--is a dishonest use of the poor single half hour in a week which is put into our hands--'Tis not preaching the gospel--but ourselves--For my own part. . . I had rather direct five words point blank to the heart-- (TS, 4.26.317).

As seen in Yorick's praise of preaching "to the heart," then, Sterne views the true function of pulpit eloquence as imparting the wisdom of the Scriptures instead of broadcasting the preacher's personal fame. To Sterne, moreover, good pulpit eloquence is not characterized by witty turns of phrase, metaphysical arguments, and elaborate diction, but by the simple, dramatic language found in the Scriptures, 
whose emotional force is furthered through the use of gestures and inflection. As Tristram points out in his comment upon Trim's dropping of the hat:

Ye who govern this mighty world and its mighty concerns with the engines of eloquence, --who heat it, and cool it, and melt it, and mollify it, --and then harden it again to your purpose --

Ye who wind and turn the passions with this great windlass, --and, having done it, lead the owners of them, whither ye think meet --

Ye, lastly, who drive--and why not, Ye also who are driven like turkeys to market, with a stick and a red clout--meditate --meditate, I beseech you, upon Trim's hat (TS, 5.7.362).

The contrast between the true wisdom of Trim's eloquence, modeled upon the direct language of the Scriptures, and the false wisdom of an eloquence modeled upon the convoluted rhetoric of the worldly wise, who might consider Trim "foolish," becomes more meaningful in light of the historical debate over the proper function of eloquence in the English pulpits. In heated debates from roughly the time of the Restoration, both Catholic and Protestant clergymen vied to assess the proper function of pulpit eloquence. R. F. Jones reminds

us that:

Prior to the restoration of Charles II . o the predominating style of preaching was characterized by affectations, fanciful conceits, metaphors, similes, plays upon words, antitheses, paradoxes, and the pedantic display of Greek and Latin quotations. After 1660 the scientific ideal of style--plainness, directness, clearness--steadily gained ascendancy over the
older manner of expression. 36

One of the first blows against the rhetorical affectations of the pre-Restoration pulpit style was struck by Charles II in his 1662 directive to the Archbishops of England concerning "the extravagance of preachers": 
The extravagance of preachers has much heightened the disorders, and still continues so to do, by the dilligence of factious spirits .... Young divines, in ostentation of learning, handle the deep points of God's eternal counsels, or wrangle about gestures and fruitless controversies. 37

The reaction against the "false" eloquence of the pre-Restoration pulpits was so acute, however, that it nearly stifled all forms of eloquence in the Anglican pulpits. ${ }^{38}$ In 1678, less than twenty years after Charles II had issued his royal decree, the Anglican apologist Joseph Glanvill pleaded for the return of some forms of pulpit eloquence.

Ironically, Glanvill had previously been one of the leading exponents of "plainness" 39 in the Established Church, but reversed his position towards the end of his career upon realizing that all forms of eloquence and displays of emotion were being suppressed from Anglican pulpits. "It is not so much our want, that we do not know our duty," he wrote in his Seasonable Defence of Preaching (1678), "as that we are dead, and cold, and averse to practice what we are acquainted with." 40 Reminding his fellow divines of the persuasive function of rhetoric, Glanvill urged the restoration of eloquence in order to "procure the affections to obey the reason." 41 Glanvili's criticism of the emotionally sterile Anglican pulpits resembles Sterne's complaint, expressed by Walter in Tristram Shandy, that while Anglican clergymen write "fine compositions," they fail to "take part in what they deliver" (TS, 2.17.141). As will be seen in the remainder of this chapter, Sterne's concept of pulpit eloquence, which Trim illustrates in his funeral oration, continues the trend established 
by Glanvill in the late seventeenth century 。

In his dramatic reading of Yorick's sermon upon abuses of conscience and in the direct appeal to the heart of his funeral oration, Trim exhibits neither the learned affectations of the pre-Restoration pulpit style nor the coldness of what $R$. F。 Jones called the "scientific ideal of style" of the Restoration. Rejecting both the stylized affectations of pre-Restoration pulpit eloquence and the unnatural severity of the post-Restoration pulpit, Sterne projects Trim as the ideal pulpit orator. Speaking in the rich but unaffected language of the Scriptures, Trim imparts wisdom despite his appearance as an intellectual simpleton. Alan McKillop reminds us of the effectiveness of Trim's funeral oration compared to Walter's attempt to gloss over death by uttering his "entire set" of "fine saying/s phy has .. f for Death" (TS, 5.3.353): "The gestures and words of Trim's oration . . acquire by incremental repetition and elaborate commentary a significance that Walter's learning never attains" (McKillop, pp。199-200). It remains for us to examine carefully the "words" of Trim's funeral oration, for his language exhibits the superiority of those wise in spirit to those learned in the false wisdom of this world.

Although Trim's non-verbal gestures, such as dropping his hat in order to illustrate man's mortality, exemplify what Martin Price has called "spontaneous movements of psychosomatic wisdom" (Price, p. 330), his wisdom most clearly manifests itself in his selection of the inspired "Word" of the Scriptures to convey the radical contingency 
of human existence. In examining Trim's use of the Scriptures in his funeral oration, we should keep in mind that Trim is no longer giving a dramatic reading of Yorick's sermon upon the abuses of conscience but is revealing both his dramatic and creative powers in his ability to weave the powerful language of the Scriptures into his own prose. For example, Trim paraphrases several Biblical texts, including I Peter 1.24 ("For all flesh is as grass, and all the glory of man as the flower of grass. The grass withereth; and the flower thereof falleth away"), when he asks:

- . are we not like a flower of the field--a tear of pride stole in betwixt every two tears of humiliation - . is not azl flesh grass? --'Tis clay, --'tis dirt (TS, 5.9.364). 42

In rejecting philosophical formulas for the wisdom of the Scriptures, Trim illustrates the Pauline concept of "the foolishness of preaching." In his First Epistle to the Corinthians, Paul explains that he was sent "to preach the gospel: not with the wisdom of words" (I Cor. 1.17). Since "the world by wisdom knew not God," Paul continues, "it pleased God by the foolishness of preaching to save them that believe" (I Cor. 1.21). In explaining Paul's meaning, Thomas Sherlock, one of Sterne's contemporaries in the Anglican priesthood, argues that when Paul discarded the "Wisdom of the World. . it took its Revenge of the Gospel, and called it the Foolishness of Preaching." The world's judgment of the gospel notwithstanding, Sherlock argues, "by this foolishness of Preaching God intends to save them who believe: For this Method is of God, and not of Man; and the Foolishness of God is wiser than Men." 43 
Henry Hammond, whom Johnson recommends to Boswell as the standard commentator on the New Testament, 44 Iikewise explains that while the substance of the Apostle's preaching--the belief in Christ crucified--"may seem a ridiculous thing to impenitent unbelievers," it is "the most glorious evidence of the power of God" to those who "have come in to Christ by repentance and faith" (Hammond, A Paraphrase, and Annotations Upon AII the Books of the New Testament, p. 511). For Hammond, the "foolishness" of preaching Christ crucified was paradoxically "wise" because the apostles gained converts to the new faith in spite of the oppositions of the worldly wise:

Let all the Philosophers and learned or searching men. . shew me so many men brought to reformation and virtuous living by their precepts, as we have done by this ridiculous way, as 'tis believed, of preaching the crucified Saviour . Doth it not appear, that all the deep wisdom of the world is become absolute folly in comparison with it? (Hammond, p. 511)

Paul's concept of the "foolishness of preaching" is not merely a subject for seventeenth- and eighteenth-century Biblical commentators. It is highly significant that Fenelon's influential rhetorical treatise Dialogues on Eloquence (1679), which "spoke against scholastic and ecclesiastical subtleties in the pulpit and recommended a flap upon the heart and imagination, "45 also advocates the "foolishness" of preaching Christ crucified rather than the "wisdom" of relying upon metaphysical arguments of philosophy. As speaker "A" points out in the "Third Dialogue" of Fenelon's treatise, Paul's "preaching.. . was founded neither upon human arguments nor human persuasions, [for 7 his was a ministry whose strength came from on high" (Dialogues, 
3.127).46 The essence of Paul's ministry, speaker "A" continues, was "the unique power of [Christ's] cross, / $[$ for 7 philosophers had argued without converting men and without being converted themselves" (Dialogues, 3.128).

Fenelon's Dialogues merit at least passing attention here because they illuminate the conviction of such traditional praisers of folly as Thomas a Kempis that the unlearned impart the lessons of Christian wisdom more effectively than the worldly wise because God has given "more understanding to meek persons, than can be given by man's teaching" (Imitatio, 3.43.173). Like Sterne, Fenelon "recognized that preaching is a phase of the larger enterprise of communication. 147 For Fenelon (speaking through "A" in the "Third Dialogue"), 48 the "power of the cross," and not "the words of men," should inform the ideal preacher's sermon:

Jesus Christ comes with his cross . . In order to silence our vain and presumptuous reason. He does not reason as do the philosophers; but he makes judgment with authority by means of his miracles and his mercy . . . To confound men's false wisdom he places before them the folly and the shame of his cross . . . What the world believes to be folly .. . is what must lead it back to God . . Walking in Christ's steps, his apostles preach him. They have recourse to no human means ... neither philosophy, nor eloquence, nor statecraft, nor riches, nor authority .... There you have human wisdom confounded and reproved. What must be the inference we draw from this? That the conversation of the peoples and the establishment of the church are not due to reasoning and to the persuasive words of men (Dialogues, 3.128-9).

Trim's use of Biblical language to remind man of the inherent corruption of his flesh dramatizes the principle set forth in Fenelon's "Third Dialogue" --that the ideal preacher rejects "the 
persuasive words of men" in favor of the inspired "Word" of the Scriptures. It is significant that during Trim's funeral oration Tristram observes that the corporal "was talking more like the chaplain than himself" (TS, 5.10.364). Tristram's observation about the similarity of Trim's speech to the chaplain's (Yorick) is no idle comment, for Trim's use of the flower image in his funeral oration is modeled upon the traditional Anglican burial service. According to "The Order for the Burial of the Dead" in The Book of Common Prayer, the priest shall read from Job 14.1,2 "whiles the corps is made ready to be laid into the earth":

Man that is born of a woman, is of few days, and full of troubles --He cometh forth like a flower, and is cut down; he fleeth also as a shadow, and continueth not.

Because Trim functions as an instrument for imparting the wisdom of Christ, Tristram's comparison of Trim to "the chaplain" in Volume $V$ becomes more significant in light of the fact that Job 14.1,2 provides Yorick with his text in "Job's Account of the Shortness and Troubles of Life Considered." "The comparison which Job makes use of, That man cometh forth like a flower, is extremely beautiful, "Yorick maintains, "and [is] more to the purpose than the most elaborate proof" (Sermons, I, 116-17)。Because Volumes V and VI of Tristram Shandy appeared in December, 1761, less than two years after Sterne published his first two volumes of sermons (which included the sermon upon Job's account of life), it appears possible that he intended Tristram's comparison between Yorick and Trim as a specific reminder of the similarity between The Sermons of Mr. Yorick and Tristram Shandy. In 
making this comparison between the Sermons and Tristram Shandy Sterne could very well, as John Traugott has remarked, be reminding his readers that "he was never really out of the preacher's habit" (Traugott, p. 99) when he was writing his novel.

Having demonstrated the brevity and contingency of human existence, Trim concludes his funeral oration by exhorting his audience to face death bravely. As will be seen, Trim's remarks at the conclusion of his funeral oration provide a frame of reference for the subject of the present study's next chapter--the contrast between Yorick's wise folly in dying fearlessly as a jester, and Tristram's unwise folly in fearfully attempting to flee from death. "I value not death at all," Trim says snapping his fingers, "What is he? A pull of a trigger--a push of a bayonet an inch this way or that--makes the difference" (TS, 5.10.365). Despite the radical contingency of man's life, Trim argues that"the best way is to stand up to him Ii.e., Death7 --the man who flies, is in ten times more danger than the man who marches up into his jaws. --I've look'd him... an hundred times in the face, --and know what he is" (TS, 5.10.365). In effect, both Trim's funeral oration and Yorick's sermon upon the brevity and troubles of Job's life dramatize the perilous uncertainty of human existence in order to remind man of his ultimately foolish attachment to the things of this world. In the last paragraph of "Job's Account of the Shortness and Troubles of Life Considered, "Yorick states:

When we reflect that this span of life, short as it is, is chequered with so many troubles, that there is nothing 
in this world springs up, or can be enjoyed without a mixture of sorrow, how insensibly does it incline us to turn our eyes and affections from so gloomy a prospect, and fix them upon that happier country, where afflictions cannot follow us, and where God will wipe away all tears from off our faces for ever and ever? (Sermons, I, 125)

In spite of the inevitablity of death, however, it is man's nature to wish to escape from it. As Trim says in the concluding sentence of his funeral oration, "And could I escape him by creeping into the worst calf's skin that ever was made into a knapsack, I would do it there . . but that is nature" (TS, 5.10.365). Whereas Sterne would not have man reject this world, he would have him recognize his folly in failing to realize his finiteness as a creature. By speaking through the compassionate Trim to remind man of his mortality and consequently of his foolish attachment to the things of this world, Sterne once again demonstrates his Erasmian double vision. Instead of philosophically inveighing against the ultimate folly of man's attachment to this world in light of the eternal joy afforded by the next, Sterne, through Trim, views man's natural attachment to the world with compassion and understanding. Whereas Sterne shares Erasmus' hope that by recognizing his own folly man will lead himself to wisdom, he also shares the humanist's conviction that "if it is... natural to be a fool, to be a fool is also to be natural. "49 Emblematic of Sterne's total acceptance of human nature, with all of its follies, is Tristram's comment upon an exchange between Trim and the chambermaid, Susannah, during Trim's funeral oration: 
--What is the finest face that ever man looked at! --I could hear Trim talk so for ever, cried Susannah, -what is it! (Susannah laid her hand upon Trim 's shoulder) --but corruption? --Susannah took it off.

--Now I love you for this--and 'tis this delicious mixture within you which makes you dear creatures what you are--and he who hates you for it--all I can say of the matter, is--That he has either a pumkin for his head --or a pippin for his heart, --and whenever he is dissected, 'twill be found so (TS, 5.9.364).

Thus far, we have seen that although various characters in Tristram Shandy are foolish, their foolishness is of different kinds. While Tristram claims to be a foolish narrator, professing ignorance of what he is about, his foolishness is wise because it exposes a different kind of foolishness--the foolish worldly wisdom exhibited by the novel's pedants. In his genuine benevolence and almost childlike trust in God, Toby demonstrates the wisdom of the "natural fool" in contrast to the worldly affectations of the novel's systematizers. Toby's constant companion, Trim, demonstrates the wisdom of the "foolishness of preaching" by exhibiting a natural eloquence far more effective than the stilted rhetoric of worldly wise orators such as Walter Shandy. In the next chapter we shall turn to what Sterne ideally viewed as the wisest folly of all in Tristram Shandy--Parson Yorick's Christian folly. 
Notes

1. For a discussion of the "fool of nature," see Kaiser, pp. 91-100. "From the Stoic point of view," Kaiser argues, "nature is foolish; from Stultitia's point of view, stoicism is folly because it denies nature" (p. 95).

2. Alan Howes points out that in the eighteenth century, "Uncle Toby was certainly the most universally admired and loved of Sterne's creations" ( $p .25)$ and quotes Leigh Hunt's observation, in his "Essay on Wit and Humour" (1846), that "even Shakespeare himself 'never arrived at a character' like that of Uncle Toby" (p. IIl).

3. A. R. Towers, "Sterne's Cock and Bull Story," ELH, XXIV (1957), 24.

4. For Sterne's hatred of the Church of Rome, see Life, pp. 86-7, 88.

5. Sterne's anti-Catholic sentiments echo those of Archbishop Tilloston who condemned the Roman Church for its "gross follies of superstition" (quoted by L. P. Curtis in Angican Moods of the Eighteenth Century New Haven, Conn., 1966/, p. 4).

6. Italics mine.

7. Walter was probably using the expression "in course" to mean "in order" or "in turn"--that is, in order or in turn of decreasing importance in a row or series (O.E.D.). Since Toby informed Walter of Trismegistus' priestly fame after Walter had praised the ancient Egyptian's fame as the greatest king, lawgiver, and philosopher, Walter's remark of "in course" shows Walter's desire to de-emphasize Trismegistus' fame as a religious leader at the expense of his more secular accomplishments.

8. I am indebted tc Philip Overton James, The Relation of 'Tristram Shandy' to the Life of Sterne (The Hague, 1966), for pointing out that in addition to those in St. Augustine, references to Trismegistus "can be found in the writings of . . . Clement of Alexandria, Lactantiu, Cyril, Stobeus, and Philo Judaeus" (p.60).

9. St. Augustine, The City of God, Book 8, chap. 24, p. 129 in The Basic Writings of St. Augustine, ed. Whitney J. Oates (New York, 1948), vol. II. AII subsequent references are to this edition and will be noted as above. 
10. Quoted by Howes, p. 112 .

11. In the chapter of his Sentimental Journey entitled "The Translation. Paris, "Yorick eulogizes the "philanthropy" of "Captain Tobias Shandy, the dearest of my flock and friends" (Journey, p. 170). All references to Sterne's A Sentimental Journey Through France and Italy by Mr. Yorick are to Stout's edition.

12. Quoted by Howes, p. 59.

13. Quoted by Howes, p. 114, n. 8 .

14. For a discussion of Sterne's emphasis upon benevolence and philanthropy in his Sermons, see Hammond, Fp. 94-98.

15. Sterne's remark that the divine injunction of loving one's neighbor extends to all men would have reminded the members of his congregation of their catechism, in which the baptismal candidate states that his duty towards his neighbor "is to love him as myself, and to do to all men as I would they should do unto me."

16. Sterne's remark is from his "dedication" of his"Charity Sermon" to Richard Osbaldeston, the Dean of York.

17. The degree of affection between the young Le Fever and Toby is indicated when the young man takes his leave of his foster parent in order to serve in the military: "The greatest injury could not have oppressed the heart of Le Fever more than my uncle Toby's paternal kindness; --he parted from my uncle Toby, as the best of sons from the best of fathers --both dropped tears--and as my uncle Toby gave him his last kiss, he slipped sixty guineas, tied up in an old purse of his father's in which was his mother's ring, into his hand, --and bid God bless him" (TS, 6.12.431).

18. Quoted by Hammond, p. 96.

19. David Owen, English Philanthropy, 1660-1960 (Cambridge, Mass., 1964), p. 11 .

20. Quoted by Owen, p. 11 .

21. "A Sermon of Christian Love and Charity, in two Parts" (1574) in The Two Books of Homilies Appointed to be Read in Churches (Oxford, 1859). Article XXXV of the Articles of Religion of the Anglican Church recommends both books of Homilies for "contain]ing] a godly and wholesome Doctrine. . necessary for these times." The first edition of the Second Book of Homilies appeared in 1563, but both books were bound up as one volume from 1623. 
22. TS, 6.7.421.

23. "An Homily of Almsdeeds and Mercifulness Toward the Poor and Needy," The Two Books of Homilies, p. 386.

24. Apocrypha (King James Version), ed. Manuel Komroff (New York, $1 9 3 7 \longdiv { \text { p. } 7 9 . }$

25. Traugott, p. 20 .

26. Stedmond, p. 84 。

27. Quoted by Curtis in Anglican Moods, p. 28.

28. Stedmond, p.83.

29. Kaiser, p.8.

30. Traugott, p. 56.

31. As Hammond has pointed out, "nearly every critic who has written about Sterne has called attention to the dramatic qualities inherent in the Sermons" ( $p .99)$.

32. Wilbur Cross has remarked of Sterne's love of the dramatic: "Sterne was more than an actor. His best sermons are embryonic dramas, in which an effort is made to visualize scene and character, as though he were writing for the stage ... For setting forth the character of . . men in Scripture, Sterne frequently impersonated them, spoke as he fancied they must have spoken, giving their points of view, their reasons for their conduct, in conversation or in monologue . . Everywhere Sterne thus lets his imagination play upon the few details furnished him by Scripture, building up scenes and character just as Shakespeare knew how to do from an incident or two out of Holinshed" (Life, pp.247-8).

33. Jonathan Swift, Gulliver's Travels, ed. Robert A. Greenberg (New York, 1961), Bk。 III, chap。ii, p. 132. All subsequent references are to this edition and will be noted as above.

34. Sterne's text for his sermon, "Our Conversation in Heaven," Sermons, II, pp.92-100。

35. In A Critical Commentary and Paraphrase on the Old and New Testament and the Apocrypha (Philadelphia and New York, 1849), vol. III, Symon Patrick points out that in Jeremiah, as in other books of the 0ld Testament, stocks and stones represent "senseless images, which are . 0 no better than what they appear to be, wood and stone" ( $p .382)$. 
36. Richard Foster Jones, "The Attack on Pulpit Eloquence in the Restoration: An Episode in the Development of the Neo-Classical Standard for Prose," in The Seventeenth Century: Studies in the History of English Thought and Literature from Bacon to Pope, ed. Richard Foster Jones (Stanford, Calif., 1951), pp. 112-13.

37. Cited by Jackson I. Cope, Joseph Glanvill: Anglican Apologist (St. Louis, 1956), po 155.

38. Jones, p. 124 .

39. For a discussion of Glanvill's position on the issue of pulpit eloquence, see Cope, pp. 144-69.

40. Cited by Cope, p. 165.

41. Cope, p. 153.

42. Cf. Ps. 36.2; Ps.102.15; Isa. 15.12; Isa. 40.6; Ecclus. 14.8; and Jas. 1.10。

43. Thomas Sherlock, D。D., Several Discourses Preached at the Temple Church (London, 1754), p. 101.

44. See Chapter One, above, p. 41, n. 54.

45. Traugott, p.87.

46. Fenelon's Dialogues on Eloquence, ed.Wilbur Samuel Howell (Princeton, N. J., 1951), "Third Dialogue," p。127. All subsequent references are to this edition and will be noted as above. On p. 37 of his "Introduction" to Fenelon's Dialogues, Howell points out that while the Dialogues were probably written in 1679, they first appeared in English in 1722.

47. Howell, "Introduction," p. 1.

48. Both speakers "A" and " $\mathrm{C}$ " believe in "rhetoric as a social instrument, not as an instrument of a speaker's personal ambition" (Howell, "Introduction," p. 5).

49. Kaiser, p. 95. 
Four: The Transcendent Wisdom of Yorick's Christian Folly

The successes of Tristram as a foolish, but wise narrator and Toby and Trim as unlearned instruments of divine wisdom anticipate the victory of Parson Yorick's Christian folly. In Chapter II of this study, it has been seen that Yorick, like Tristram, functions as a court jester in puncturing the pride of the worldly wise. This chapter will show that Yorick, in his capacity as a wise fool for Christ, goes beyond the satirical function he shares with Tristram. Yorick's Christian folly, manifesting itself primarily in his acceptance of death as the beginning of life, provides a norm against which Sterne asks us to test the various kinds of wisdom and folly represented in the novel. In particular, Yorick's Christian folly exposes Tristram's foolish lack of Christian wisdom in attempting to flee from death in Volume VII of his life and opinions.

The first section of this chapter will discuss the Christian dimension of Yorick's wise folly, particularly through Sterne's allusions to Hamlet and Don Quixote. Section two will discuss the "dialectic" between Tristram's foolish wisdom in fleeing death, and Yorick's wise folly in accepting death, in terms of such contrasting Christian motifs as the "OId Man" and the "New Man," and the "Old Dance" and the "New Dance." Section three will consider A Sentimental Journey as Sterne's final vision of Christian folly. 
One way in which Yorick's Christian folly becomes evident is in his embodiment of the "foolish" Christian virtue of humility, instead of the "wise" attribute of "affected gravity." Tristram points out that Yorick was not opposed to

. . gravity as such; --for where gravity was wanted, he would be the most grave or serious of mortal men for days and weeks together; --but he was an enemy to the affectation of it, and declared open war against it, only as it appeared a cloak for ignorance, or for folly (TS, 1.11.26).

In contrast to the pretentious kinds of worldly wisdom exhibited by Walter Shandy and by the polemic divines at the canonical dinner, Yorick exhibits Christian humility, as we have seen, by refusing to preach himself instead of the gospels and more generally, by choosing to "bear the contempt of his enemies, and the laughter of his friends, [rather] than undergo the pain of telling a story, which might seem a panegyric upon himself" (TS, 1.10.22).

Yorick's humility can best be understood as a kind of intellectual humility which exposes through contrast the pretentiousness of worldly wisdom and which results from his ability to make the Augustinian distinction between worldly knowledge (scientia) and true wisdom (sapientia). ${ }^{1}$ Although Yorick is "inquisitive after all kinds of knowledge" (TS, 2.17.142), he avoids Walter Shandy's error of equating worldly knowledge with the highest form of wisdom. An example of Yorick's ability to distinguish between knowledge and wisdom occurs when Walter is explaining part of his Tristrapoedia to Yorick, Toby and Trim. Citing the "first book of the Institutes of Justinian" as his authority, walter argues that the "son ought to pay [his mother7 
respect" in spite of "the natural relation between a father and his child" (TS, 5.31.391). Yorick's reply--"I can read it as well.. in the Catechism" (TS, 5.31.392) --indicates his wisdom in regarding the Scriptures as a superior source of wisdom. Unlike the "pretenders" to wisdom whom Sterne castigates in his sermon "Advantages of Christianity to the World" for mistakenly assuming that "our titles to wisdom [are] built upon the same basis with those of our knowledge, and that they will continue for ever" (Sermons, II, 55), Yorick wisely distinguishes between worldly knowledge and Christian wisdom.

The wisdom of Yorick's Christian folly becomes more evident in light of Sterne's allusions to Hamlet and Don Quixote at the beginning of Volume I of Tristram Shandy. Informing Yorick's satiric role in Tristram Shandy with an allusive richness of meaning, the relationship between Sterne's Yorick and Shakespeare's also points to the former's normative role as a fool for Christ. Carefully establishing Parson Yorick's Danish lineage, Tristram reports that the parson's ancestor "could be no other than... the king's chief Jester; --and that Hamlet's Yorick, in our Shakespear, . . was certainly the very man" (TS, 1.11.24). Yorick's "open war" on the "affectation of gravity" and his habit of "meditat/Ing7 . . delightfully de vanitate mundi et fuga saeculi" (TS, 1.10.20) probably corresponded to the satiric functions performed by Hamlet's chief jester. "Now get you to my lady's chamber," Prince Hamlet addresses Yorick's skull, "and tell her, let her paint an inch thick, to this favor she must come. Make her laugh at that" (Hamlet, V, i, 11.180-82)。 Like Hamlet's Yorick and other 
professional court fools of the Middle Ages and the Renaissance, who served as "commentators on the follies of mankind, "2 Parson Yorick of Shandy Hall reminded Sterne's readers of the vanity of human wishes.

The analogous functions performed by Parson Yorick, and his Danish ancestor in Hamlet's court, extend to the symbolic implications of their respective deaths. Yorick's skull in Hamlet recalls to the youthful prince the vanity of human wishes in light of universal mutability. "Symboliz/ing] all his disillusionment, ${ }^{3}$ the skull of Prince Hamlet's beloved court companion causes him to dwell upon the "base uses [to which7 we may return." Addressing Horatio, Hamlet asks: Why may not imagination trace the noble dust of Alexander till 'a find it stopping a bunghole?" (Hamlet, V, i, 11.190-92) ${ }^{4}$ Tristram's account of Yorick's fate at the hands of a vengeful world, together with the Shakespearean epitaph on his grave ("Alas, poor Yorick!"), and the black page at the end of Chapter twelve, likewise provide a memento mori for the reader about to commence his long journey through the story of Tristram's life and opinions.

Significantly, Yorick's grave with its Shakespearean epitaph is placed near "a foot-way crossing the church yard" (TS, 1.12.32), thus serving to remind all travelers of this world's mutability and vanity. Tristram's reference to the "passengers" traveling by Yorick's grave underscores the traditional theme of life as a long journey, which Tristram introduces to his story by referring to the "Homunculus" as a "young traveller" (TS, 1.2.6). 6 Strategically placing Tristram's description of Yorick's life and death at the beginning of the novel, 
Sterne seems to be providing us with a norm to judge the actions of the novel's other characters. ? Sterne's allusions to Shakespeare's Hamlet reinforce the wisdom of Parson Yorick's acceptance of death as a part of life. Dramatizing the message of Sterne's sermon upon Phillipians 3.20, Yorick's death reminds us that "our conversation is in heaven":

- . we must have our conversation in heaven, whilst upon earth, --make it the frequent subject of our thoughts and meditations, --let every step we take tend that way . . forgetting those things which are behind; --forgetting this world, --disengaging our thoughts and affections from it, and thereby transforming them to the likeness of what we hope to be hereafter (Sermons, II, 97).

Although Yorick's function in Tristram Shandy is similar to his ancestor's function in Hamlet, Parson Yorick's temperament differs from that of his Danish ancestor. Parson Yorick "seem'd not to have had one single drop of Danish blood in his whole crasis" (TS, 1.11.25), Tristram informs us. "Instead of that cold phlegm and exact regularity of sense and humours, you would have look'd for, in one so extracted," Tristram continues, Yorick "was, on the contrary, as mercurial and sublimated a composition, --as heteroclite a creature in all his declensions . . as the kindliest climate could have engendered and put together" (TS, 1.11.24). The difference in temperament between Parson Yorick and his Danish ancestor suggests the difference between the Renaissance and the medieval versions of the Christian fool. Like his Danish ancestor in the medieval court of King Hamlet, Yorick reminds man of the vanity of the world and the swift passing of time. In his ability to jest at death in the closing moments of his life, however, 
Yorick is, as we shall see, more akin to the Erasmian fool for Christ than to the medieval advocates of the idea of contemptus mundi. We recall that at the end of her praise of folly, Stultitia eulogizes the fool for Christ who manifests not a monastic withdrawal from the world but an indifference to the external things of this world resulting from his anticipation of the eternal joys of the next.

Sterne's allusions to Don Quixote, whom Walter Kaiser calls the "last of the great Renaissance fools" (Kaiser, p. 277), 9 further suggests Parson Yorick's kinship to the Renaissance fools for Christ. Early in the story of his life and opinions, Tristram claims that "with all his [Don Quixote's] follies," he loved the Don "more, and would actually have gone further to have paid a visit to, than the greatest hero of antiquity" (TS, 1.10.22). Like Don Quixote mounted upon Rosinante, the "spare ... figure" (TS, 1.10.19) of Yorick mounted upon his steed never failed to attract attention. In Yorick's "sallies about his parish," Tristram tells us, "he never could enter a village but he caught the attention of both old and young" (TS, 1.10.19). Tristram's comparison of Yorick and Don Quixote even extends to the similarity between their horses, for the parson's steed "was full brother to Rosinante," and "was as lean, and as lank, and as sorry a jade, as HUMILITY herself could have bestrided" (TS, 1.10.18). In spite of his humorous appearance, Yorick's "spiritual and refined sentiments" earn Tristram's praise, for they compare to "any of the honest refinements of the peerless knight of La Mancha" (TS, 1.10.22). 
Tristram's references to Don Quixote are examples of "the presence of Cervantes. . Which7 is felt in one place or another of every volume of Tristram Shandy $" 10$ Other well-known references to Cervantes occur in Tristram's praise of his "dear Rabelais, and dearer Cervantes" (TS, 3.19.191) and in his invocation to the "GENTLE Spirit of sweetest humour, who erst didst sit upon the easy pen $\overline{\overline{\text { of my }}}$ beloved CERVANTES" (TS, 9.24.628). Tristram's favorable comparison of Yorick to Don Quixote, and the explicit references to the genius of Cervantes in Tristram Shandy, support Stuart Tave's contention that together with Fielding, Sterne "must have been a major influence in teaching his readers to identify amiability with Cervantes."II

Pope's observation that Don Quixote was "the perfection of the MockEpick"12 epitomizes the earlier eighteenth-century view that Cervantes was, in Tave's words, "primarily . o a satirist" (Tave, p.153), with Don Quixote the butt of his satire.

In his study of "the function of the norm" in Don Quixote, Oscar Mandel shows that beginning with the eighteenth century, readers of Don Quixote have "tended to join one of two critical schools, depending on their interpretations of the role played by the knight." 13 According to the "hard school" of readers, Mandel argues, Quixote is merely an object of satire for attempting to revive the chivalric code in an unchivalrous age. To the "soft school," on the other hand, he is a noble exemplar of Christian virtue, for he ibegins [as] a buffoon, but ...ends [as7 a martyr."14 Tristram's favorable comparison between Don Quixote and Yorick, and his eulogies to Cervantes 
and Don Quixote, suggest that Sterne would fall into the so-called "soft school" of readers in his evaluation of Cervantes' knight. Similar to Don Quixote's dedication to the chivalric code of honor and virtue, Yorick's practice of Christian virtues is misunderstood by a world which has ceased to practice them. A case in point is the way in which the members of Yorick's parish maliclously distort his charity into pride. Tristram reports that Yorick, at his own expense, established a midwife in his parish, thereby saving his parishioners from the hardship of riding "six or seven long miles" (TS, 1.12.7) away in order to find one. Prior to his establishment of a midwife in his parish, Yorick was continually lending his horse to his parishioners to fetch the neighboring midwife. The upshot of Yorick's unselfishness, Tristram adds, was that he "had every nine or ten months a bad horse to get rid of" (TS, 1.10.21). Having established a midwife in his own parish, Yorick decided to discontinue his impractical and unnecessary custom of annually purchasing a new horse, because it

- . confined all his charity into one particular channel, and where, as he fancied, it was the least wanted, namely, to the child-bearing and child-getting part of his parish; reserving nothing for the impotent, --nothing for the aged, --nothing for the many comfortless scenes he was hourly called forth to visit, where poverty, and sickness, and affliction dwelt together (TS, 1.10.21).

As Tristram points out, however, the "world at that time was pleased to determine the matter otherwise" (TS, 1.10.17). Instead of appreciating Yorick's charity in providing them with a midwife, and respecting his good sense in distributing his help where it was most 
needed, his parishioners viewed Yorick's action as "a returning fit of pride" (TS, 1.10.22). For Yorick's parishioners, "'twas plain as the sun at noon-day, that] he would pocket the expense of the [midwifeis] license, ten times told the very first year" (TS, 1.10.22). As with Don Quixote, whose code of knight-errantry is mocked by the world while he lived, but praised by the world as he lay on his deathbed, ${ }^{15}$ so Yorick is misunderstood during his lifetime. It was "about ten years ago," Tristram reports, that Yorick "had the good fortune to be made entirely easy upon that score /his establishment of a midwife], it being just so long since he left his parish, --and the whole world at the same time behind him, --and stands accountable to a judge of whom he will have no cause to complain" (TS, 1.10.23).

To a great extent, then, Sterne's description of Yorick as a quixotic figure (TS, 1.10.18-20,22) conforms to the "soft" school's reading of Don Quixote as a hero who seeks the "eternal," but who "falls afoul of the persecutors of the world." of Yorick as a quixotic figure may be seen as an idealized projection of the kind of life that Sterne, with understandable reservations, saw himself leading. In a letter to Bishop Warburton, written in the summer of 1760, Sterne commented upon the consequences of his quixotic redressing of wrongs:

These strokes in the Dark, with the many Kicks, Cuffs and Bastinados I openly get on all sides of me, are beginning to make me sick of this foolish humour of mine of sallying forth into this wise and wicked world to redress wrongs, etc. of which I shall repent as sorely as ever Sancha Panca did of his in following his evil genius of a Don Quixote through thick and thin--but as the poor fellow apologized for it, --so 
must I: 1 t was my vile fortune and my Errantry and that's all that can be said on't (Letters, No. 63, p. 116).17

As seen in his letter to Warburton, and other epistolary allusions to his quixotic redressing of wrongs, 18 Sterne intended his readers to associate his maltreatment at the hands of critics and fellow clerics, idealized in Tristram's account of Yorick's life and death, with the world's maltreatment of Don Quixote.

In spite of the censure which he accurately foresaw in 1760 , Sterne did, of course, continue his knight-errantry in Tristram Shandy, by turning praise of worldly wisdom into blame, and blame of Christian folly into praise. Yorick's courage in "choosing rather to bear the contempt of his enemies. . than undergo the pain of telling a story, which might seem a panegyric upon himself" (TS, 1.10.22) reflects Sterne's rejection of what he contemptuously called the "understrapping Virtue of Prudence" (Letters, No. 38A, p. 76). Yorick's courage becomes more admirable in light of his disregard for Eugenius' "lecture upon discretion." Tristram reports that Eugenius, in his "lecture upon discretion" (TS, 1.21.28), repeatedly had warned Yorick of the vengeful "temper of the world":

- . trust me, Yorick, When to gratify a private appetite, it is once resolved upon, that an innocent and an helpless creature shall be sacrificed, 'tis an easy matter to pick up sticks enew from any thicket where it has strayed, to make a fire to offer it up with (TS, 1.12.29).

The fulfillment of Eugenius' prediction. Tristram reports, caught the unsuspecting Yorick completely by surprise. There was "so little suspicion in Yorick, of what was carrying on against him, -that when he thought.. . full surely preferment was o'ripining, -his enemies] had smote his root, and then he fell, as many a worthy 
man had fallen before him" (IS, 1.12.30). To a certain extent, Yorick's early death, at the age of twenty-six, may be viewed in the same way as A. R. Towers has aptly viewed the assortment of physical 1lls plaguing Tristram; that is, as the price that "the fool or jester, like the related figure of the holy simpleton, so often pays for his freedom."19 In spite of the price which he pays, however, Yorick achieves a victory over this world and its transitory rewards. Not only does Yorick now stand before "a judge of whom he will have no cause to complain" (TS, 1.10.23), but the "general pity and esteem" which travelers by-passing his grave express for him "ten times in a day" (TS, 1.12.32) when they utter his Shakespearean epitaph justify Yorick's faith in "trust/ing] to time and truth" (TS, 4.27.324) to vindicate him in the eyes of an unjust and ungrateful world.

The religious overtones of Eugenius' "lecture upon discretion," with its warning to Yorick about the world's indifference in "sacrificing" an innocent and an helpless creature, " recall the martyrdom to $\operatorname{truth}^{20}$ of the wise fool, Don Quixote. Although Don Quixote dies completely disillusioned by the failure of the world to accept the truth of his chivalric ideals, ${ }^{21}$ the world belatedly sees that the quest of Cervantes' knight-errant for truth has indeed led to the wisdom of Christ. After Don Quixote makes a dramatic deathbed renunciation of "those damnable Books of Knight-Errantry" which had cast "a Cloud of Ignorance" over his "Understanding" (Don Quixote, 2.74. 930), 22 his friends plead that he become a fool again and assure him that "the Lady Dulcinea is dis-inchanted [sic]," and that they are 
"upon the point of turning Shepherds, to sing, and live like Princes" (Don Quixote, 2.74.931). Although Don Quixote dies disillusioned, Walter Kaiser argues, "his foolish life has caused the world to see the wisdom of folly" (Kaiser, p. 296). The Christian wisdom of Don Quixote's folly is evinced in his advice to Sancho Panza, given while Don Quixote was still under the spell of knight-errantry: "First of all, $O$ my Son, fear God; for the Fear of God is the beginning of Wisdom -... Secondly, Consider what thou wert, and make it thy Business to know thy self, which is the most difficult Lesson in the World" (Don Quixote, 2.52.719). If Quixote is mad, his madness is that of the divine fool. Ironically, the bachelor Samson, who had been the spokesman of this world's contempt for Quixote's kind of folly, utters the final eulogy to the wisdom of folly, in the form of his epitaph on Quixote's grave:

The Body of a Knight lies here,

So brave, that, to his latest Breath, Immortal Glory was his Care, And makes him triumph over Death.

His Looks spread Terror every Hour:

He strove Oppression to controul;

Nor cou'd all Hell's united Pow'r Subdue or daunt his Mighty Soul,

Nor has his Death the World deceiv'd Less than his wondrous Life surpriz'd;

For if he like a Madman liv'd, At least he like a Wise One dy'd (Don Quixote, 2.74.935).

To say that Yorick, like Don Quixote, dies completely disillusioned with the world, however, would be to misrepresent Yorick's role as an Erasmian fool for Christ. While both Don Quixote and 
Yorick are fools in the Renaissance tradition, Yorick does not exhibit the "mournful countenance" which is associated with Cervantes' protagonist. Yorick, Tristram reminds us, exuded "as much life and whim, and gaité de coeur about him, as the kindliest climate could have engendered and put together" (TS, 1.11.25)。 In assessing Quixote's place in the Renaissance tradition of fools, Walter Kaiser writes: "In the close of the Renaissance, the fool's laughing face takes on an aspect of tragedy and sadness, and the last of the great Renaissance fools is known to the world for his mournful countenance" (Kaiser, p. 277). Although Yorick's dying words to his friend Eugenius suggest his disenchantment with the world, we shall see that both the tone of Yorick's words and the glint in his eyes inform his deathbed speech with an air of hopeful anticipation concerning his passage into the next world. "Take a view of my head," Yorick asks Eugenius, and - . let me tell you, that 'tis so bruised and mis-shapen'd with the blows which... have so unhandsomely [been7 given me in the dark, that I might say with Sancho Panca, that should I recover, and "Mitres thereupon be suffer'd to rain down from heaven as thick as hail, not one of 'em would fit it" (IS, 1.12 .31 ).23

Tristram's observation that Yorick uttered his last speech "with something of a cervantick tone" (TS, 1.12.31), however, mitigates our sorrow over Yorick's death because Tristram's observation suggests a distinction between quixotic disillusionment and Christian hope that the injustices of this world will be rectified in the next world. We recall that when Don Quixote returns to his senses and makes a deathbed renunciation of his books of knight-errantry, "the world prays him to become a fool again and assures him that his illusions were 
indeed realities."24 Quixote's inability to perceive either the fickleness of this world or the irony of hoping to achieve truth in such a fickle world is evinced in his solemn reply to the pleas and assurances of his friends:

No more of that, I beseech you ...; all the Use I shall make of these Follies at present, is to heighten my Repentence; and though they have hitherto prov'd prejudicial, yet by the Assistance of Heaven, they may turn to my Advantage at my Death: I find it comes fast upon me, therefore, pray Gentlemen, let us be serious (Don Quixote, 2.74.931).

Unlike Don Quixote, the Knight of the Mournful Countenance, Yorick "saw himself in the true point of ridicule" (IS, 1.10.19), and his ability to see the folly of his own actions prevents him from falling into quixotic disillusionment. Yorick's ability to perceive the irony of hoping to achieve truth and justice in a deceitful and unjust world is not only evinced in the "cervantick tone" of his dying words, but also in the "stream of lambent fire" which Eugenius observed "lighted up for a moment in [Yorick's] eyes; --faint picture of those flashes of his spirit, which (as Shakespeare said of his ancestor) were wont to set the table in a roar!" (TS, 1.12.31) By describing the tone of Yorick's last speech as "cervantick" rather than "quixotic," Tristram seems to suggest that in his final moments Yorick exhibits a degree of perception about the world which Don Quixote does not exhibit in his final moments. At the end of Don Quixote, in other words, Cervantes makes the reader see what the character, Don Quixote, does not: the irony of the world's encouragement of the very knight-errantry which it had previously condemned. At the end of Yorick's life, however, both the reader and Yorick are aware of this world's injustice 
and inconstancy and perceive the wisdom of preparing for the immutable joys of the next world.

Thus, while Tristram's placement of Yorick's death at the beginning of the novel reminds man of mutability and the transitoriness of life, his description of Yorick's manner of accepting death suggests Yorick's role as a Christian fool. From the point of view of the Christian fool, Walter Kaiser has argued, "external things become in themselves indifferent, neither good nor bad except as our mind or heart deems them good or bad" (Kaiser, p. 180). The Christian fool's ultimate perception of the indifference of external things is his last jest. While the conventional clown has traditionally viewed death as life's last joke, 25 the fool for Christ has the last laugh, because only he sees death as the beginning of a more meaningful life.

\section{II}

While the allusions to Hamlet and Don Quixote illuminate Parson Yorick's normative function as a Christian fool, the analogy between the Tristram-Yorick relationship in Tristram Shandy and the PanurgePantagruel relationship in Book III of Rabelais is particularly instructive in distinguishing Tristram's imperfect folly from Yorick's perfect folly in Christ. Sterne's debt to his "dear Rabelais" (TS, 3.19.191) has often been considered deeper than his debt to cervantes. 26 In his Dictionnaire philosophique (1771), Voltaire went so far as to refer to Sterne as "le second Rabelais d'Angleterre." 27 Alan B. Howes notes that the anonymous reviewer for the Critical Review II (April, 
1761) summarized a general view of Sterne's debt to Rabelais when he contended that "Rabelais rather than Cervantes has furnished the 'pattern and prototype' for Tristram Shandy 'in the address, the manner, and colouring '" (Howes, p. 14).

Functioning as a foil to Parson Yorick, Tristram, like Panurge, fails to achieve the wisdom of Christian folly even after experiencing the folly of worldly wisdom. We recall that Panurge fails to achieve Pantagruel's Christian folly in his inability to accept God's will in determining the future. "As long as he tries to determine the future," Walter Kaiser says of Panurge, "so long will the future worry him and prevent his will from being free" (Kaiser, p. 174). Tristram exhibits a striking similarity to Panurge's inability to accept God's will in determining the future when he vaunts to Eugenius at the beginning of Volume VII that he "will lead [Death7 a dance he little thinks of" (TS, 7.1.480). Tristram's vaunt is occasioned by Death's unexpected knock upon his door. "There is no living," Tristram tells Eugenius, . . at this rate; for as this son of a whore has found out my lodgings... and as thou seest he has got me by the throat... and that I am no match for him in the open field, had I not better, whilst these few scatter'd spirits remain, and these two spider legs of mine . . are able to support me... fly for my life? (TS, 7.1.480) ${ }^{28}$ Tristram's inability to defer his will to the divine will in this matter of his death prevents him from achieving the wisdom of Parson Yorick's Christian folly, just as Panurge's inability to defer to God's will prevents him from achieving Pantagruel's Christian folly. 
Tristram's failure in Volume VII to follow Yorick's example has been prepared for in Volume IV where Tristram wavers between "esteem" and "blame" (TS, 4.27.324) of Yorick's refusal to abandon his quixotic redressing of wrongs in the name of prudence and discretion. "All I blame him for," Tristram says of Yorick, "or rather, all I blame and alternately like him for, was that singularity of his temper, which would never suffice him to take pains to set a story right with the world, however in his power" (TS, 4.27.324)。 To Tristram, for whom Yorick's fate at the hands of the world is another example of this world's maltreatment of its fools, Yorick's flaw was his chronic lack of discretion. "He was a man unhackneyed and unpractised in the world," he writes of Yorick, "and [he] was altogether - . indiscreet and foolish on every .. . subject of discourse where policy is wont to impress restraint" (TS, 1.11.26-27).

Tristram's failure to become wise in the foolishness of Christ becomes evident in his failure to prepare for the next world while journeying through this one. Tristram's failure to prepare himself for what Sterne called, in his sermon, "The House of Feasting and the House of Mourning Described, "man's "main errand" in "Jerusalem" (Sermons, I, 15) is seen in Tristram's inability to maintain a proper balance between the houses of feasting and of mourning in his journey through France in Volume VII. Sterne's sermon, which he described in a letter as "one of the best" of his efforts (Letters, No. 183, p. 301), is based upon Ecclesiastes 7.2,3: "The heart of the wise is in the house of mourning; but the heart of fools is in the house of mirth." 
Carefully attempting to impart a sense of balance between the houses of feasting and of mourning, Sterne observes that although we are "mournful traveller s" on a "weary pilgrimage," we "may surely be allowed to amuse ourselves with the natural or artificial beauties of the country we are passing through, without reproach of forgetting the main errand we are sent upon" (Sermons, I, 14-15). Not to amuse ourselves in this way "would be a nonsensical piece of saint errantry" Sterne adds, "if we can so order it, as not to be led out of the way, by the variety of prospects, edifices, and ruins which solicit us" (Sermons, I, 15).29 As if to emphasize the importance of his qualification to man's enjoyment of worldly pleasure, Sterne reminds his congregation in the very next paragraph of his sermon that man's "main errand" is to prepare for the next world:

Let us remember, various as our excusions are, --that we have still set our faces towards Jerusalem ... and that the way to get there is not so much to please our hearts, as to improve them in virtue; --that mirth and feasting are usually no friends to atchievements sic] of this kind--but that a season of affliction is in some sort a season of piety . . because our sufferings... allow us what the hurry and bustle of the world too often deny us, --and that is, a little time for reflection, which is all that most of us want to make us wiser and better men (Sermons, I, 15-16). 30

As in his sermon, Sterne employs the journey motif in Volume VII of Tristram Shandy. Tristram's prediction at the beginning of the novel that his "life and opinions.. . will . . be no less read than the Pilgrim's Progress itself" (TS, 1.4.7) indicates Sterne's intention of employing the journey motif in Volume VII in its medieval and Renaissance sense, as "a form of pilgrimage.. . from this world to the next," as well as in its typically eighteenth-century sense, 
as "an occasion for a kind of Lockean discovery." 31 Although Tristram Shandy is by no means a solemn imitation of Bunyan's Christian allegory, Tristram's allusion to Pilgrim's Progress at the beginning of his story announces Sterne's intention of writing a Shandean version of the "pilgrimage of the soul" theme. He presents his version of the pilgrimage of the soul theme by contrasting Yorick's Christian folly in preparing for "Jerusalem" to Tristram's unwise folly in "forgetting the main errand we are sent upon" in his flight to France to escape Death.

One way in which this contrast between the kinds of folly exhibited by Tristram and Yorick may be viewed is by analogy to the distinction between the Pauline figures of the "Old Man" and the "New Man" (Col。3.9-10; Eph. 4.22-4; and Rom。6.6). ${ }^{32}$ In summarizing the distinction between the "Old Man" and the "New Man," Robert Po Miller points out:

As an aspect of the nature of man, the vetus homo represents the flesh and its manifold lusts, opposed to the novus homo: that is, the spirit and reason, by which these are subdued. In terms of the Biblical history of man, the Old Man in any human being, is the image of fallen Adam, unregenerate in accepted grace and unredeemed by Christ, Who is called the "New Man." As the result of original sin, all men are said to be born in the image of the vetus Adam. By baptism, however, we are said to die to sin and to be reborn in the image of Chrisst; and he who adopts this image is termed the New Man。

In his deathbed indifference to the rewards of this world and in his anticipation of the immutable joys of the next, Yorick may be likened to Paul's "New Man." It remains for us to identify the links between Tristram and Paul's "01d Man." 
One of the possible links between Tristram and the Biblical "Old Man" is evinced in Tristram's interest in gambling throughout his flight from Death in Volume VII. One step in the "Old Man's" "progression along the road to spiritual death," D. W. Robertson, Jr. has pointed out, is "the submission to Fortune implied by gambling." 34 In spite of Tristram's frantic flight from Death, epitomized in his observation that he was "pursued. . like a hundred devils" (TS, 7.7.287), Tristram remains long enough in Boulogne with two of his fellow "debtors and sinnersbefore heaven" to comment upon their throws in a dice game: "Well thrown size-ace .. well thrown, size-Ace, again!" (TS, 7.7.487) Tristram's interest in gambling is further indicated in his use of terms from piquet, a two-handed card game, to describe an inn-keeper's daughter named Janatone to the reader: "She has a little of the devote: but that, sir, is a terce to a nine in your favour" (TS, 7.9.491). ${ }^{35}$ Commenting upon his own infatuation with Janatone, Tristram adds:

-- L help me! I could not count a single point: so had been piqued and repiqued, and capotted to the devil (TS, 7.9.491). 36

Although the evidence presented in the three passages above does not in any way prove that Sterne was overtly comparing Tristram to the Biblical "Old Man," the evidence does indicate enough similarity between the two figures to justify further examination of the relationship between them.

Another example of Tristram's kinship with Paul's "Old Man" is evinced in Tristram's invocation to the pagan deities. Predicting 
that the phallic rites of classical antiquity will replace the practice of Christianity in "half a century" (TS, 7.14.495), 37 Tristram regrets that he will not live long enough to participate in them:

Blessed Jupiter! and blessed every other heathen god and goddess! for now ye will all come into play again, and with Priapus at your tails--what jovial times! --but where am I? and into what a delicious riot of things am I rushing? I--I who must be cut short in the midst of my days, and taste no more of 'em than what I borrow from my imagination (TS, 7.14.495).

Unlike Yorick, whose "gaité de coeur" (TS, 1.11.25) did not manifest itself in an obsessive attachment to the joys of this world at the expense of his ultimate duty toward the next, Tristram becomes more and more associated with the "Old Man" who, D. W. Robertson points out, traditionally represents "the inherited evil habit of the flesh" (Robertson, p. 127).

A less conclusive but no less admissible piece of evidence in the case for linking Tristram with Paul's "Old Man" appears in Tristram's promise, made while he is traveling through Calais, that "naked" as he is, he will not burden the reader with a fifty-page account of the siege of Calais in 1346 :

- . ere I would force a helpless creature upon this hard service, and make thee pay, poor soul! for fifty pages which I have no right to sell thee, --naked as I am, I would browse upon the mountains, and smile that the north wind brought me neither my tent or my supper (TS, 7.6.486-87).

In the passage quoted above, Tristram seems to be using "naked" to refer figuratively to the physical hardships of hunger and poor living quarters traditionally experienced by authors because of their unstable incomes. Within the context of the analogies already presented between 
Tristram and the "Old Man," however, Tristram's admission of nakedness may also refer to his moral bankmptcy before God in foolishly attempting to flee Death. D. Wo Robertson reminds us that in traditional Christian iconography, the "Old Man" is seen as "a naked fool, or man without the spiritual clothing of virtue" (Robertson, p. 132).

Sterne uses both the physical and the moral senses of nakedness in his sermon "The Prodigal Son" when he observes that the young man who leaves his homeland for foreign parts at too early an age "may . . be said to escape well--if he returns to his country, only as naked, as he first left it" (Sermons, I, 235). For Sterne, one of the chief potential advantages of traveling is that by "seeing the difference of so many various humours and manners," we may "look into ourselves and form our own" (Sermons, I, 235). However, Sterne continues, "the impulse of seeing new sights . . carries our youth too early out, to turn this venture i.e., traveling 7 to much account" (Sermons, I, 235). In view of Sterne's use of nakedness in "The Prodigal Son" to suggest a lack of moral growth, then, Tristram's admission of nakedness in Volume VII may well be taken not only as an admission of his physical hardships but also as an admission of a moral failure before God similar to that of the "Old Man."

Perhaps the most striking example of Tristram's association with Paul's "Old Man" is seen in the salacious nature of his journey through France. We recall his observation in Chapter nine that he had been "piqued... repiqued, and capotted to the devil" by Janatone. A similarly implicative experience occurs in Chapter forty-three when he 
conducts an "affair of trade" with a Provencal "gossip" for a basket of figs. Upon purchasing the figs, Tristram discovers that "there were two dozen eggs cover'd over with vine leaves at the bottom of the basket" which he "had no intention of buying" (TS, 7.43.535). A "short contention" ensues between buyer and seller because Tristram has no intention of parting with the basket, which he needs to carry the very ripe figs, and the woman wants the basket back in order to hold her eggs. Commenting upon the outcome of their "contention," Tristram says to the reader:

--How we disposed of our eggs and figs, I defy you, or the Devil himself, had he not been there (which I am persuaded he was) to form the least possible conjecture (TS, 7.43 .536$)$.

In spite of Tristram's defiant challenge to the reader, one may well conjecture, in view of the sexual connotations of eggs and figs, 38 that Tristram's "affair of trade" was concerned with more than just eggs and figs.

Still another example of Tristram's salaciousness is evinced in his flirtation with a "chere fille" whom he compliments as she emerges from matins in Boulogne: "Ah! ma chere fille! . . you look as rosy as the morning .. (she made a curt'sy to me--I kiss'd my hand)."39 In this particular incident, Tristram exhibits not only his attachment to the "house of feasting" but also the spiritual impoverishment to which his preoccupation with that house alone has led him, for he suggests that the "chere fille" is responsible for the figure of Death whose shadow stalks him throughout his journey through France. He says to her: 
--How can you be so hard-hearted, MADAM, to arrest a poor traveller going along without molestation to any one, upon his lawful occasions? do stop that death-looking, longstriding scoundrel of a scare-sinner, who is posting after me--he never would have followed me but for you (TS, 7.7.487).

On the one hand, Tristram's words might indicate a perception that his obsession with the flesh, of which this girl becomes merely a symbol, has actually hastened his physical decline and perhaps has even contributed to his spiritual death. Since there is no other real indication that Tristram does perceive his folly in these matters, however, it might be more to the point to interpret Tristram's absurd suggestion that the "chere fille" is responsible for the stalking figure of Death as a failure either to recognize or accept the role of divine will in determining matters of life and death.

Furthermore, this failure to recognize and defer to the will of God and the inevitability of death is indicative of Tristram's failure to meet his responsibility of properly preparing himself to enter Jerusalem by keeping a balance between the houses of feasting and mourning. As sterne points out in his sermon, the "house of mourning" is a "more instructive school of wisdom" than the "house of feasting" because, by revealing to a man the "miseries and misfortunes, the danger and calamities to which the life of man is subject... the "house of mourning"7 forces [him] to see and reflect upon the vanity, --the perishing condition and uncertain tenure of everything in this world" (Sermons, I, 22). Unlike Yorick who sat "mechanically" on his horse in order to meditate.. delightfully de vanitate mundi et fuga saeculi" (TS, 1.10.20), 40 Tristram has neglected the "house 
of mourning" on his journey since he has not gained a clearer perception of the "uncertain tenure" of humanly ordered affairs than that indicated by his suggestion that the "chere fille" rather than God is responsible for his impending death. Tristram has failed to achieve the Christian wisdom necessary to enter Jerusalem because, Sterne points out in the same sermon, he has not allowed "a little time for reflection, which is all that most of us want to make us wiser and better men" (Sermons, I, 15-16).

Tristram's lack of Christian wisdom is further indicated in this same scene by his assertion, in connection with his desire to remain and court the "chere fille" that he has "no debt but the debt of NATURE" (TS, 7.7.487). "I want but patience of her, "Tristram adds about his "debt of nature," and "I will pay her every farthing I owe her" (TS, 7.7.487). In not only failing to recognize God's disposition of these matters of life and death, but also in foolishly believing that he can exercise some measure of control himself, Tristram further exhibits a kinship with Paul's "Old Man."

Tristram's sexual desire for Nannette, whom he meets at the end of his journey in southern France, epitomizes the salacious nature of his journey and his kinship with Paul's "Old Man." While traveling by mule between Nismes and Lunel, Tristram stops and dismounts when he sees Nannette, "a sun-burnt daughter of Labour" (TS, 7.43.537), and a group of peasants preparing to dance. Sterne's description of Tristram's stay with Nannette and the peasant dancers abounds with images of sexual suggestiveness, from the "cursed slit" (TS, 7.43.537) in Nannette's petticoat, to the oath uttered by Tristram's mule to "saint Boogar, and all the saints at the 
back side of the door of purgatory" (TS, 7.43.537). 41 Observing that the peasants are "running at the ring of pleasure," Tristram tells his mule that he will "take a dance" (TS, 7.43.537). In noting Sterne's use of the phrase "running at the ring of pleasure" in A Sentimental Journey, Gardner Stout points out that "'running at the ring' [is] a chivalric exercise in which a rider attempted to pass the point of his lance through a suspended ring," while "ring" is "a slang term for the female pudendum" (Stout, ASJ, p. 156, n. 14). Sterne's use of the phrase "running at the ring of pleasure" in A Sentimental Journey to connote participation in the joys of the flesh suggests that his employment of the phrase in Tristram Shandy was intended to underscore Tristram's attachment to the pleasures of this world.

After leading him by the hand to the group of dancers, Nannette, all of whose hair, but for a tress, was bound up in a knot, infatuates Tristram with her "self-taught politeness" and natural ease:

Tie me up this tress instantly, said Nannette, putting a piece of string into my hand--It taught me to forget I was a stranger--The whole knot fell down--We had been seven years acquainted (TS, 7.43.537-38).

The sexual connotations of "Boogar," "slit," and "knot"l2 all suggest, then, that Tristram's desire to "take a dance" is a symbolic expression of his sexual desires.

Tristram's preoccupation with the flesh throughout Volume VII, epitomized in his desire to end his days dancing with Nannette, may be viewed in terms of the "Old Man's" desire to participate in the sexual pleasures of what was known in medieval art as the "Old Dance" rather 
than in the spiritual joys of the "New Dance."43 In his "preface" to the study of Chaucer, D. W. Robertson points out that the Pauline tradition of the "New Man" versus the "Old Man" is related to the medieval traditions of the "New Song" (charity) versus the "Old Song" (cupidity) and the "New Dance" versus the "Old Dance" (Robertson, p. 127). Pictorial representations of the "Old Dance" often depicted the devil leading a group of dancers, Robertson informs us, while representations of the "New Dance" often featured "an angel leading some saints... in a dance" (Robertson, p. 130). 44 The "Old Dance is the dance of formication, spiritual or physical," Robertson adds, and "this is the sense in which it appears in the Roman de la Rose" (Robertson, p. 131). While we cannot prove that Sterne was alluding to or even barely hinting at the tradition of the "Old Dance" in his depiction of Tristram's dance with Nannette, we can, on the basis of the links between Tristram and the "Old Man," view Tristram's desire to end his days dancing with Nannette in terms of the sexual symbolism of the "Old Dance."

In the middle of his dance with Nannette, Tristram becomes even more linked with Paul's "Old Man" when he addresses an impossible petition to heaven:

--Why could I not live and end my days thus? Just disposer of our joys and sorrows, cried $I$, why could not a man sit down in the lap of content here--and dance, and sing, and say his prayers, and go to heaven with this nut brown maid? (TS, 7.43.538)

Tristram's petition to heaven exemplifies his kinship with Paul's "Old Man" because it reveals the foolishness of his hope to earn salvation 
after actively participating in the transitory joys of this world without contemplating the necessity of preparing himself for the eternal happiness of the next world. As indicated by his references to the figure of Death throughout his travels in France, and in his references to various symptoms of his mortal sickness, such as the "vile cough" which he dreads "worse than the devil" (TS, 7.1.479), ${ }^{45}$ Tristram should, particularly as an Anglican priest, be directing his thoughts toward preparing himself for his imminent state.

Tristram's failure to fulfill the spiritual imperative of the journey--preparing himself for the next world--may be measured by the standards for "spiritual traveling" which Sterne himself set forth in his sermon "The House of Feasting and the House of Mourning Described." As seen in his desire to spend the remainder of his days dancing with Nannette, Tristram is a fool from the perspective of God because he has neglected his "main errand" in Jerusalem, as reflected in his failure to maintain a proper balance between the houses of mourning and of feasting. As we have seen, through the links between Tristram and the Biblical "Old Man," Tristram has become obsessed with the "house of feasting" throughout his journey through France in Volume VII. In his sermon upon Ecclesiastes 7.2.3., Sterne warned that even "the most cautious" and the "most circumspect" of men are not free from the danger of committing "indiscretion--perhaps... folly" while visiting the "house of feasting" (Sermons, I, 19). Even though Tristram is far from cautious or circumspect, as seen in his desire to "live and end Khis days" in "the lap of content" with Nannette, he 
still thinks he can "go to heaven with [his] nut brown maid" (TS, 7.43.538). According to the precepts expressed in Sterne's sermon, Tristram cannot have the best of both worlds until he demonstrates an awareness that his "main errand" is in Jerusalem. Tristram's failure to maintain a proper balance between the houses of mourning and of feasting has rendered him incapable of amusing himself "without reproach" (Sermons, I, 15) with the pleasures of this world and perhaps has even rendered him unworthy of entering Jerusalem.

Up to this point, I have suggested, through the analogies between Tristram and Paul's "Old Man," that Tristram's flight from physical death has ironically hastened his "progression along the road to spiritual death. $1{ }^{46}$ Tristram's progress along the road to spiritual death, characterized by a pre-occupation with the "house of feasting" to the exclusion of the "house of mourning," becomes increasingly more evident in Sterne's allusions to La Danse Macabre, or the "Dance of Death" in Tristram Shandy. In his study of the Dance of Death, James M. Clark informs us that:

By the Dance of Death we understand literary or artistic representations of a procession or dance, in which both the living and the dead take part. The dead may be portrayed by a number of figures, or by a single individual personifying Death. The living members are arranged in some kind of order of precedence, such as pope, cardinal, archbishop, or emperor, king, duke. The dance invariably expresses some allegorical, moral or satirical idea.47

The first reference to the Dance of Death in Tristram Shandy occurs in Walter's philosophical oration upon Bobby's death when Walter re-minds Toby that "'monarchs and princes dance in the same ring with us'" (TS, 5.3.353). While La Danse Macabre, which Barbara Swain has called 
a "pageant of human folly" in medieval art and literature (Swain, p. 65), is unrelated to the traditions of the "Old Man" and the "Old Dance," it merits our attention here because of its significance in placing Tristram's attempt to avoid death within a context of human folly.

As Walter's reminder to Toby about "monarchs and princes" suggests, one of the ideas which La Danse Macabre has traditionally conveyed is the equality of all men before death. 48 In the famous painting of the "Dance" which embellished Old Saint Paul's in London, for example, Death led a row of dancers comprised of "the King, the beggar, the old man, the child, the wise man, and7 the fool. "49 In other representations of La Danse Macabre, such as the Holbein woodcuts, the "Dance" consisted of "a series of isolated groups," in which Death is depicted in the process of escorting individuals, one at a time, from every social level. 50 One of the individuals whom Death was often depicted leading away from this world was the fool. In one such striking pictorial representation, probably from the early Renaissance, Death is wearing the fool's cap and bells as he sardonically leads his foolish victim away. 51

Within the context of the above information about La Danse Macabre, Tristram's vaunt of leading Death on "a dance he little thinks of . . to the world's end (TS, 7.1.480) accmes a dimension of folly even greater than that apparent in his association with the "Old Man." Because Tristram is, by his own admission, a fool, his Flace in the line of dancers in Ia Danse liacabre should be behind, not in front of, Death. Yet, throughout his ;ourney throush France. 
Tristram maintains the original vain assumption, expressed to Eugenius in the first chapter of Volume VII, that he, Tristram, was going to "lead" (TS, 7.1.480) Death on a dance in order to gain more time in which to write his life and opinions" 52 and in order to enjoy the "house of feasting." Tristram's foolishness in attempting to flee from Death in order to gain time is seen in two of his direct references to the figure of Death. Before his arrival in Ailly au clochers, Tristram laments that he "must be cut short in the midst of my days" (TS, 7.14. 495) and then begs Death to let him continue his journey: "Peace to thee, generous fool! and let me go on" (TS, 7.14.495). The irony of Tristram's description of Death as a "generous fool" is that Tristram, not Death, is the "fool" for presuming that he is worthy of any special dispensation from Death.

Another example of Tristram's foolish vanity in presuming that he can avoid Death occurs toward the end of his journey in southern France. After slowing down the frantic pace which has characterized his journey in France, Tristram observes:

--for I had left Death, the lord knows--and He only--how far behind me--"I have followed many a man thro' France, quoth he-but never at this mettlesome rate" --Still he followed, --and still I fled him--but I fled him cheerfully--still he pursued-but like one who pursued his prey without hope--as he lag'd, every step he lost, softened his looks--why should I fly him at this rate? (TS, 7.42 .534 )

Tristram's foolishness here is evinced in his failure to act wisely in accordance with his realization that only the "lord knows" how far Death is trailing behind him. As we have seen in the case of Parson Yorick, the Christian fool wisely defers his will to God's, thereby achieving freedom from anxiety about such humanly indeterminable issues 
as life and death. Tristram, on the other hand, is like the unwise fool Panurge because he continually wants to determine the future. "As long as he tries to determine the future," Walter Kaiser says of Panurge, in a statement which could just as easily have been made about Tristram, "so long will the future worry him and prevent his will from being free" (Kaiser, p. 174).

The foolishness of Tristram's attempt to determine the future may be measured in terms of Sterne's praise for the Biblical figure of Jacob in his sermon "The History of Jacob Considered." Praising Jacob for trusting in God during the "few and evil" days of his earthly pilgrimage, Sterne speaks to his congregation as he fancied Jacob might have prayed to his creator:

--Grant me, gracious God! to go cheerfully on, the road which thou hast marked out; --I wish it neither more wide or more smooth: --continue the light of this dim taper thou hast put into my hands; --I will kneel upon the ground seven times a day, to seek the best track I can with it--and having done that, I will trust myself and the issue of my journey to thee, who art the fountain of joy, --and will sing songs of comfort as I go along (Sermons, II, 8-9).

Tristram's fallure to trust in God's gracious plan for the duration of his temporal journey prevents him from achieving the blissful calm exhibited by Jacob in his prayer and the fearless acceptance of death exhibited by Yorick in his dying speech to Eugenius.

Failing to trust God, Tristram is imprisoned by a mood of anxiety throughout most of his journey. Ironically, he has never really "led" Death as he boasted he would, but has run from Death; thus, Death has been the master all along--an inevitability suggested in all the representations of La Danse Macabre. The anxiety-ridden 
nature of Tristram's journey is evident in his words which continually indicate that he is a man pursued rather than a free man in command of his fate. For instance, he says that he left his study "like a cannon" (TS, 7.3.482), and calls himself a "man in haste" (TS, 7.3.482), and says he "wrote galloping" while being "pursued like a hundred devils" (TS, 7.7.487). Even towards the end of his journey in Southern France he says of Death, "still he followed, --and still I fled him" (TS, 7.42.534).

In such haste, Tristram's journey becomes frustrating to the extent that he never manages to see all the sights he had planned on seeing, such as the thirty-volume history of China contained in the Jesuit library in Lyons. When Tristram claims that "nothing can prevent us [from7 seeing" the Chinese history, his servant François replies: "except the time . . f for 'tis almost eleven--then we must speed the faster, said I, striding it away to the cathedral" (TS, 7.39. 531). Francois' reminder about the time proves correct because in realizing that "my time was short" (TS, 7.39.532), Tristram loses interest in seeing the Chinese history:

Now it is with the project of getting a peep at the history of China in Chinese characters--as with many others I could mention, which strike the fancy only at a distance; for as I came nearer and nearer to the point--my blood cool'd--the freak gradually went off, till at length I would not have given a cherry-stone to have it gratified--The truth was, my time was short (TS, 7.39.532).

This incident typifies the effect of Tristram's anyiety about his lack of time in this world on his ability to enjoy his journey.

Another example of the effect of Tristram's anxiety on his ability to enjoy himself is that he is unable to enjoy fully even those 
pleasures of the flesh with which he is so obsessed. In the cases of the three young women previously discussed as objects of Tristram's desires, he abbreviates his visits because he feels compelled to keep running from Death. His haste prevents him from remaining with either the "chere fille" or Janatone (he tells the reader that his "reason for haste" in fleeing from her is a "bad" one--i.e., Death). 53 Even in the case of Nannette his anxious haste is evident in his reaction to her nearly successful attempt to seduce him into spending the rest of his days with her "in the lap of content" (TS, 7.43.538).

Capriciously did she bend her head on one side, and dance up insiduous--Then 'tis time to dance off, quoth I; so changing only partners and tunes, I danced it away from Lunel to Monpellier--from thence to Pescnas, Beziers-I danced it along through Narbonne, Carcasson, and Castle Naudairy, till at last I danced myself into Perdril $\overline{l o ' s}$ pavillion, where pulling a paper of black lines, that I might go on straight forwards, without digression or parenthesis, in my uncle Toby's amours--

I begun thus-- (TS, 7.43.538).

The final irony of Tristram's flight from Death, then, is that it becomes a flight from life. In attempting to win more time for himself in this world, Tristram, at the end of Volume VII, has paradoxically lost time by wasting it in frantically racing from the "son of a whore" Death. Freedom from the fear of death, and consequently, freedom to enjoy this world and use his allotted time to its fullest advantage, would have resulted from deference to God's will and from contemplation of the eternal joys of the next world. But Tristram has not even allowed himself enough time for "reflection" (Sermons, I, 16) in the "house of mourning." In rejecting the spiritual imperative of his journey Tristram has failed to achieve the 
Christian wisdom which would have given him that freedom. In his folly, then, Tristram has not only come nearer to spiritual death, but has even lost this world in the process. In A Sentimental Journey, as we shall see in the concluding section of the present chapter, the "Sentimental Traveller" Yorick is able to participate in the pleasures of the "house of feasting" without losing sight of his main errand in Jerusalem. Like the Christian fool, Parson Yorick of Shandy Hall, the "Sentimental Traveller" Yorick likewise demonstrates that folly in the eyes of man may lead to wisdom in the eyes of God.

\section{III}

According to Richard Griffiths, the editor of the Monthly Review, Sterne referred to A Sentimental Journey Through France and Italy By Mr. Yorick 54 as his "Work of Redemption." 55 "Perhaps, "Gardner Stcut has recently noted, "Sterne's reference to A Sentimental Journey as his 'Work of Redemption' was not simply a jesting expression of hope that the book would redeem his reputation and fortune" (Journey, Introduction, " p. 40, n. 43), both of which were suffering from the lukewarm critical reception of Volumes III-VIII of Tristram Shandy. 56 In his Sentimental Journey, the "Sentimental Traveller" (Journey, p. 83) Yorick, unlike Tristram in his flight from Death, redeems the time that is his in this world by cultivating "all the benevolent sentiments widely regarded during the eighteenth century as the essence of virtue. ${ }^{57}$ Because he cultivates these benevolent sentiments, Yorick fulfills Paul's exhortation to the Ephesians to "walk circumspectly, 
not as fools, but as wise, Redeeming the time" (Eph. 5.15,16). By properly utilizing his time in this world to help prepare himself for the eternity of the next world, moreover, the "Sentimental Traveller" Yorick continues the program of wise folly in Christ initiated by Parson Yorick of Shandy Hall. 58

Yorick's achievement of Christian folly in his Sentimental Journey becomes evident when seen against the background of Tristram's foolish flight from Death in Volume VII of Tristram Shandy. 59 Unlike Tristram, who travels to flee Death, Yorick views travel "as one step towards knowing himself" (Journey, p. 83). At the end of Volume I of the Journey, Yorick meets an old French officer at the Opera Comique, who tells him that "the advantage of travel, as it regarded the sçavoir vivre, was by seeing a great deal both of men and manners; it taught us mutual toleration; and mutual toleration. . . taught us mutual love" (Journey, p. 181). Commenting upon the French officer's advice, Yorick says "'twas my own way of thinking--the difference was, I could not have expressed it half so well" (Journey, p. 181). We may recall that Tristram, in order to maintain his furious pace, "cannot stop a moment to give... the character of the people--their genius--their manners --their customs--their laws" (TS, 7.19.502). Only towards the end of his journey, when it is too late to redeem all the time he has wasted, does Tristram slow his pace to seize "every handle.. . which chance held out to me in this journey" (TS, 7.43.536).

In the first chapter of Volume II of his Journey, Yorick says that the French officer's advice upon traveling reminds him of 
Polonius' advice to Laertes upon the same subject in Shakespeare's Hamlet: "This above all, to thine own self be true" (Hamlet, I, iii, 78). Yorick's recollection of Polonius' advice to his son is a reference to the theme of self-knowledge which runs throughout A Sentimental Journey. As Gardner Stout has pointed out, "Yorick's Sentimental Journey can - . be regarded as a kind of 'parable' or 'fable' illustrating the perplexities, and the possibility, of fulfilling the eighteenthcentury moral imperative to know thyself" (Journey, "Introduction," p. 43). Unlike Tristram, whose lack of identity is indicated by his inability to identify himself to the French tax collector (TS. 7.33. 525), Yorick describes himself as a "Sentimental Traveller," thereby fulfilling his conviction that determining one's "own place and rank in the catalogue /of travelers 7 . . Will be one step towards knowing himself" (Journey, pp. 82-83).

As Alan McKillop and Gardner Stout have recently shown, however, Yorick is not only a benevolent sentimentalist, or "man of feeling," but also, like his Shakespearean ancestor, and like Yorick of Shandy Hall, a man of infinite jest. ${ }^{60}$ Yorick's jesting nature is perceived by the lover of Shakespeare, "the Cornt de B B interview with the Count in Versailles. The purpose of Yorick's interview is to solicit the Count's help in applying to the Duke of Choiseul, who has the legal authority to deny or grant Yorick a passport allowing him to continue traveling in France without fear of imprisonment. At the start of the interview, Yorick indicates his jesting nature when he introduces himself by opening the Count's copy of Hamlet and placing his own finger upon the name of Yorick in the grave-digger's scene in 
Act V. "Me, Voici!" Yorick exclaims (Journey, p. 221). The Count, in spite of Yorick's protestations, literally takes Yorick at his word, refusing to distinguish between the flesh and blood Yorick with whom he is talking and the "king's chief jester" in Hamlet. "'Twas all one," the Count insists (Journey, p. 227).

The Count de $\mathrm{B}$ **her probably insists that his guest and the character Yorick in Shakespeare's Hamlet are "one" because of the unorthodox and entertaining manner in which Yorick introduces himself and because of the reason which Yorick gives for desiring to remain in France. "I have come laughing all the way from London to Paris," he explains to the Count, "and I do not think Monsieur le Duc de Choiseul is such an enemy to mirth, as to send me back crying for my pains" (Journey, p. 216). Because the Count considers Yorick a jester, like his Shakespearean namesake, he is able to persuade the Duke of Choiseul to grant Yorick a passport permitting him to remain traveling in France. "Un homme qui rit," the Duke tells the Count, "ne sera jamais dangereus" (Journey, p. 226).

Gardner Stout's suggestion that "perhaps the Count is right in replying "Twas all one'" (Journey, p. 223 n) has important implications for the concept of Christian folly as it appears in Yorick's Sentimental Journey. The fact that Yorick is "un homme qui rit," as we shall see in the love-feast he shares with a peasant family near Lyons, is a sign that he possesses the spirit of joy in the creation which is akin to the ardor of the early Christians whom Stultitia praised at the end of her Praise of Folly: 
Take the example of the first founders of religion. Embracing simplicity they became the most severe enemies of learning. And, finally, what fool could possibly act more foolishly than those whom the ardor of religion has totally consumed? They throw away their wealth, they neglect injuries, permit themselves to be deceived, fail to discriminate between friend and foe... . What is this other than insanity? It gives credence to the fact that the Apostles appeared drunk on new wine and Paul seemed mad in the eyes of the Judge Festus" (Folly, p. 169).

Having been allowed by the Duke to continue his "quiet journey of the heart in pursuit of NATURE, and those affections which rise out of her, which make us love each other--and the world, better than we do" (Journey, p. 219), Yorick is able to put into practice his thesis that a man should travel as "one step towards knowing himself" (Journey, pp. 82-83). For example, in the chapter entitled "The Temptation. Paris," he exhibits an admirable degree of self-knowledge by admitting to carnal desire for a young fille de chambre who has come to his hotel room to enquire about him on behalf of her mistress. As Yorick sits next to the young girl on his bed, he says, in reference to an earlier lecture he had given her about virtue (Journey, p. 189), "I felt the laurels shake which fancy had wreath'd about my head" (Journey, p. 236). Like Yorick in Tristram Shandy, who "saw himself in the true point of ridicule" (TS, 1.10.19), the "Sentimental Traveller" Yorick exhibits the potential to achieve Christian wisdom because he knows himself and thus can view objectively the foolishness of his own pretentions to wisdom.

By knowing himself, Yorick, unlike Tristram, is able to utilize his time in this world to his best advantage in preparing for the eternal joys of the next world. This does not mean, however, that 
Sterne intended life's traveler to renounce the God-given joys of the world while undertaking his journey through life. On the contrary, Gardner Stout points out:

Parson Yorick consistently affirms his belief that participation in the God-given joys and pleasures of our present state is a redemptive process, in two principal senses: first, it enables us to achieve a measure of temporal blessedness and, thereby, to strengthen the virtues which will enable us to participate in the joyful beatitude of eternal blessedness. And second, it saves us from the vices which can deprive us of the joys of this world and even, perhaps, of the next (journey, "Introduction," pp. 30-31).

As we shall soon see, Yorick's ability to maintain a proper balance between the houses of "feasting" and "mourning" sharply contrasts with Tristram's failure to maintain such a balance, thereby further underscoring the distinction between the former's wise folly and the latter's foolishness.

Among the virtues cultivated by Yorick on his Journey, which will enable him to "participate in the joyful beatitude of eternal blessedness," are benevolence and compassion for all forms of creation. In a manner reminiscent of Toby, the exemplar of Christian charity in Tristram Shandy, Yorick exhibits compassion for the starling trapped in its cage, the dwarf at the Opera Comique, the beggars who invariably surround his coach when he stops at an inn, the distinguished recipient of the Order of St. Louis ${ }^{62}$ who was reduced by circumstance into selling pastries on a Paris street corner, and the peasant weeping for the death of his faithful donkey. The analogy between the "Sentimental Traveller" Yorick and Tristram's uncle Toby is instructive here, because in his Sentimental Journey, Yorick refers to "Captain Tobias Shandy [äs] the dearest of my flock and friends, whose philanthropy 
I never think of at this long distance from his death--but my eyes gush out with tears" (Journey, p. 170).

While Yorick's "heart" may be "as erratic as Tristram's head," Rufus Putney points out, 63 it is, nonetheless, a compassionate one. Yorick's compassion for all who suffer confinement is initiated by his hearing the plaintive lament of the starling trapped in its cage-"'I can't get out--I can't get out'" (Journey, p。197). "I never had my affections more tenderly awakened," he says as he reflects on the "bitter draught" of slavery which "thousands in all ages" have been made to swallow (Journey, p. 199). ${ }^{64}$ Yorick's reflections on the universality of human suffering "within this little span of life" (Journey, $p .114$ ) cultivates the virtues of benevolence and compassion within him, thereby inspiring him to go "like the Knight of the Woeful Countenance, in quest of melancholy adventures" (Journey, p. 270).

Yorick's description of himself as a quixotic knight-errant not only recalls Tristram's description of Parson Yorick's quixotic cast in Tristram Shandy, but also provides a context for establishing the wisdom of the "Sentimental Traveller's" folly. For some readers of the Journey, represented most notably by Rufus Putney, Yorick's self-portrait as a quixotic knight-errant underscores his role as the butt of Sterne's "comic purpose." 65 According to Putney, "Yorick is a Cervantic hero led into ludicrous extravagances by the hyper-sensibility of his heart." 66 In view of Stuart Tave's statement that together with Fielding, Sterne "must have been a major influence" (Tave, p. 159) in transforming Don Quixote from a satiric butt to "a noble symbol" (Tave, p。 155), Yorick's "ludicrous extravagances" may be 
viewed as another illustration of the Pauline paradox that what appears to be folly in the eyes of man is really wisdom in the eyes of God.

In support of Tave's contention about Steme's attitude toward Don Quixote, Gardner Stout has recently shown that Yorick's quixotic search for melancholy adventures indicates his interest in cultivating those "virtues which will enable him7 to participate in the joyful beatitude of eternal blessedness" (Journey, "Introduction, " p. 31). Yorick most clearly exhibits these virtues, particularly those of compassion and benevolence, when he digresses from his established route and seeks out the deranged Maria, the same "luckless maiden" (Journey, p. 276) whom Tristram encountered in Volume IX of his life and opinions. The reactions of Tristram and Yorick to the plight of Maria epitomize the differences between their two journeys. As Tristram points out to his "dear Jenny" towards the end of his story, "Time wastes too fast: every letter I trace tells me with what rapidity Life follows my pen" (TS, 9.8.610). Still haunted by the spectre of Death which followed him in Volume VII, Tristram is unable to spend more than a few passing moments listening to the "tale of woe" which Maria plays to him on her pipe: "Adieu, Maria! --adieu, poor hapless damsel! -some time, but not now, I may hear thy sorrows from thy own lips" (TS, 9.24.631).

In contrast to Tristram, who chanced upon Maria on his way to Moulins, Yorick deliberately seeks her out, "like the Knight of the Woeful Countenance, in quest of melancholy adventures"(Journey, p. 270). Ordering his servant and his postilion to go on without him, Yorick compassionately shares the maiden's grief for the loss of her 
faithless lover and of her father, who died "of anguish for the loss of [his daughter's7 senses" (Journey, p.270).

Maria's physical appearance and her description of her pilgrimage to Rome suggests that Sterne intended Maria to serve as an analogue of the "lamb of God." "She was dress'd in white," Yorick observes, and attached to "a pale green ribband . . . hung a pipe" (Journey, p. 271), with which she "play'd her service to the Virgin" (Journey, p. 274). Maria's description of her pilgrimage to Rome explicitly identifies her as a "lamb of God":

She had . . . stray'd as far as Rome, and walk'd round St. Peter's once--and return'd back--that she found her way alone across the Apennines--had travell'd over all Lombardy without money--and through the flinty roads of Savoy without shoes--how she had borne it, and how she had got supported, she could not tell--but God tempers the wind, said Maria, to the shorn lamb (Journey, p. 272).

Because simple-minded innocents like Maria were considered by the Middle Ages to be under the special dispensation and protection of God, 67 Yorick's solicitous care for her suggests his role as an agent of Christian charity and of divine providence.

Yorick's compassionate desire to "shelter" Maria and his willingness to have her "eat of [his] own bread, and drink of /his cup" (Journey, p. 273), 68 illustrates the idea of the Good Samaritan which informs Sterne's sermons. ${ }^{69}$ Yorick's realization of the ideal of the Good Samaritan is particularly evident in his farewell remarks to Maria, which are paraphrased from Luke 10.33-34:

Adieu, poor luckless maiden: --imbibe the oil and wine which the compassion of a stranger, as he journieth on his way, now pours into thy wounds--the being who has twice bruised thee gan only bind them up for ever (Journey, p. 276). 
Unlike Tristram, then, Yorick cultivates the virtues of compassion and benevolence, thereby enabling himself to maintain an ideal balance between the houses of "feasting" and of "mourning." As epitomized by his first remark upon leaving Maria, a curious ejaculation about the "excellent inn at Moulins!" (TS, 9.24.631), Tristram is incapable of the kind of compassion exhibited by the "Sentimental Traveller" Yorick.

Rufus Putney's comments upon the Marla episode in A Sentimental Journey 1llustrate the argument of those who view Yorick's displays of sentiment as ludicrous and foolish. For Putney, the Maria episode "has given the] most of fense to those who have thought Sterne serious," for it is "the one in which the extravagance of Yorick's feelings and the pseudo-solemnity of his comments render him most humorous." 71 As I have tried to show in this concluding section of my study, however, the foolishness of Yorick's sentiments is indicative less of the ludicrous excesses of a self-deluded fool than of the wise folly of the Sternean fool for Christ. As he passes through the province of Bourbonnais at the height of the harvest season, Yorick cannot forget the impression left upon him by Maria's sufferings: "in every scene of festivity I saw Maria in the back-ground of the piece, sitting pensive under her poplar" (Journey, p. 277). Unlike Tristram, upon whom Maria's sufferings make no visible impression, Yorick cannot forget the "house of mourning," as represented by "this gate of sorrow, "through which he has passed in his "journey in the vintage" (Journey, p. 277). 
The fact that Yorick's famous apostrophe to "the great--great SENSORIUM of the world!" (Journey, p. 278) occurs during his trip through the Bourbonnais, further indicates his ability to cultivate those "virtues which will enable /him7 to participate in the joyful beatitude of eternal blessedness" (Journey, "Introduction," p. 31). In his apostrophe, which is partially "adapted from Matthew 10: 29-31," "72 Yorick recognizes that his compassion for his fellow man reflects God's infinite love for all of His creation:

--Dear sensibility! source inexhausted of all that's precious in our joys, or costly in our sorrows! thou chainest thy martyr down upon his bed of straw--and 'tis thou who lifts him up to HEAVEN--eternal fountain of our feelings! --'tis here I trace thee--and this is thy divinity which stirs within me---not, that in some sad and sickening moments, "my soul shrinks back upon herself, and startles at destruction" --mere pomp of words! --but that I feel some generous joys and generous cares beyond myself--all comes from thee, great--great SENSORIUM of the world! which vibrates, if a hair of our heads but falls upon the ground, in the remotest desert of thy creation (Journey, pp.277-78).

By recognizing that his compassionate feelings for his fellow man manifest the divinity within himself, Yorick exhibits the perfect joy of the Christian fool. Like the patriarch Jacob in Sterne's sermon on "The History of Jacob," for whom "gracious GOD" is "the fountain of joy" (Sermons, I, 8-9), and, like the wise fool, Stultitia, Yorick recognizes Christ as "the flowing fountain of eternal happiness." 73

This perfect joy in Christ is emblematic of the spirit of joy in the creation which characterizes the concluding section of Yorick's Sentimental Journey. Exhibiting the happiness of the primitive Christians who, Stultitia points out, "appeared drunk on new wine" (Folly, p. 169), Yorick shares a supper of bread and wine with a peasant family 
in the Bourbonnais. His description of the supper is reminiscent of the feast of agape, practiced among the early Christians as a symbol of affection and brotherhood: 74

They were all sitting down together to their lentil-soup; a large wheaten loaf was in the middle of the table; and a flaggon of wine at each end of it promised joy thro' the stages of the repast--'twas a feast of love (Journey, p. 281). Yorick's participation in the love feast, in the chapter significantly entitled "The Supper," recalls an earlier instance of his reference to another practice of the early Christians. While departing from the young fille de chambre who has accompanied him from the Parisian bookseller's shop, Yorick expresses a desire to seal their departure "with a kiss of charity, as warm and holy as an apostle" (Journey, p. 191). Although his desire to revive an established practice of the early Christians may only mask less exalted motives, his previous questions to the fille de chambre--"Tut!. . . are we not all relations?" (Journey, p. 191)--captures the spirit of the "natural bond of brotherhood" between men which Sterne praises in Christ's disciples. 75

In the next chapter of his Sentimental Journey, entitled "The Grace," Yorick once again exhibits the perfect bliss of the Sternean fool for Christ in the God-given joys of creation. As he watches the festive dance of the children and grandchildren of the peasant couple, he shares with the dancers a kind of transcendent joy in the creation:

It was not till the middle of the second dance, when, from some pauses in the movement wherein they all seemed to look up, I fancied I could distinguish an elevation of spirit different from that which is the cause or the effect of simple jollity. --In a word, I thought I beheld Religion 
mixing in the dance--but as I had never seen her so engaged, I should have look'd upon it now, as one of the illusions of an imagination which is eternally misleading me, had not the old man, as soon as the dance ended, said that this was their constant way; and that all his life long he had made it a rule, after supper was over, to call out his family to dance and rejoice; believing, he said, that a cheerful and contented mind was the best sort of thanks to heaven that an illiterate peasant could pay--

---Or a learned prelate either, said I (Journey, pp. 283-84).

Yorick's passionate expression of joy as he watches the peasants give thanks to heaven exemplifies Sterne's observation in his sermon "The Prodigal Son" that "when the affections. . kindly break loose, Joy, is another name for Religion" (Sermons, I, 233) and Stultitia's description of the happiness of the primitive Christians. 76 In his comment upon Yorick's description of the peasant dance, Gardner Stout even suggests "that there is a vital correspondence between the spirit of temporal blessedness which invests the supper and the grace, and the kindred spirit which presides over the Lord's Supper" (Journey, "Introduction," p.39).

Unlike Tristram, whose frantic flight from Death does not leave him time to participate without anxiety in the God-given joys of creation, and whose kinship to Paul's "Old Man" results in his imposing a prurient cast upon innocent pleasures, Yorick illustrates the Christian fool's conviction that, "with God's wisdom, external things become - . neither good nor bad except as our mind or heart deems them good or bad." 77 "Let every man be fully persuaded in his own mind, "Paul exhorts the Romans (Rom. 14.5), in a phrase which, Walter Kaiser has pointed out, is echoed in Book III of Rabelais and Hamlet. 78 So, too, in Yorick's Sentimental Journey, the achievement of self-knowledge 
enables the "Sentimental Traveller" to attain the greater knowledge that his cultivation of the virtues of compassion and benevolence, while appearing to be foolish in the eyes of men, is wisdom in the eyes of God. As Gardner Stout reminds us at the conclusion of his "Introduction" to A Sentimental Journey,

Yorick's Sentimental Journey illustrates the truth of St. Paul's observation that by "professing themselves to be wise, -men become7 fools," and also demonstrates that by professing themsèlves fools, men can become wise. (Journey, p. 46).

Because he is both a "man of infinite jest" and a "Sentimental Traveller," then, Yorick is distinctively a Sternean fool for Christ, personifying a combination of some of the various aspects of Christian folly exhibited by Sterne's other characters: Parson Yorick's ability to laugh in Tristram Shandy, and Toby and Trim's benevolence and compassion for the sufferings of their fellow men. Yorick's Sentimental Journey thus demonstrates the redeeming force of benevolence and compassion, virtues traditionally dismissed by worldly wisdom as foolish in their failure to profit man in his temporal pursuits. One of the truths which we have seen reverberate throughout all of Sterne's writings, however, is that "the foolishness of God is wiser than men" (I Cor. 1.25). 
Notes

1. See Chapter I, above, p。39, n. 32.

2. Enid Welsford, The Fool: His Social and Literary History (London, 1935), p. 128 .

3. Kaiser, p. 273.

4. William Shakespeare, The Tragedy of Prince Hamlet of Denmark ed. William Farnham (Baltimore, 1957).

5. In "Tristram Shandy's Wit," JEGP, LXV (January 1966), Eugene Hnatko points out that "of all the recurrent similitudes, the two most often resorted to are those centering on the journey and those about military action. Some forty similitudes come from the nexus of journey, road, travel" (55).

6. For a full discussion of Sterne's use of the "Homunculus," see Louis Landa, "The Shandean Homunculus: The Background of Sterne's "Little Gentleman'" in Restoration and Eighteenth-Century Literature, ed. Carroll Camden (Chicago, 1963), pp. 49-68.

7. "We seem to have in Yorick," John Stedmond argues, "the closest thing to a 'norm' against which to test the clown-hero's world" (p. 69). Stedmond does not develop his suggestive insight.

8. Cf. Sterne, "Our Conversation in Heaven," Sermons, II, 94: "It is observable, that St. Peter represents the state of Christians under the same image, of strangers on earth, whose city - . is heaven: --he makes use of that relation of citizens of heaven."

9. See Kaiser, pp. 277-96, for his discussion of Don Quixote as "the last of the great Renaissance fools."

10. Life, p. 140. For a catalogue of Sterne's borrowings from Cervantes, see Gardner D. Stout, Jr., "Some Borrowings in Sterne from Rabelais and Cervantes," ELN, III (1965), 111-17.

11. Stuart M. Tave, The Amiable Humorist: A Study in the Comic Theory and Criticism of the Eighteenth and Early Nineteenth Century (Chicago, 1960), p. 159. 
12. Quoted by Tave, p. 153.

13. Oscar Mandel, "The Function of the Norm in Don Quixote," MP, LV (1957-58), 153.

14. Mandel, 154.

15. I am generally indebted in this section to Kaiser's discussion of Don Quixote as the last Renaissance fool, particularly pp. 295-96.

16. Mandel, 154.

17. In "Some Borrowings in Sterne from Rabelais and Cervantes," Gardner Stout has shown that Sterne, in his letter to Warburton, was paraphrasing Sancho Panza's admission of folly in following his foolish master, Don Quixote: "I am a Fool that's certain, for if I'd been wise, I had left my Master many a fair Day since; but it was my Luck and my vile Errantry, and that's all can be said on't'" (116). As we have seen, Sterne's fears about the outcome of his role as knight-errant were not ill-founded. Notwithstanding his claim to "have Burn'd More wit, then [sic7 I have publish'd" (Letters, No. 38A, p. 77), he retained a sufficient amount of wit in Tristram Shandy to guarantee the censure of both critics and fellow clerics, including Warburton himself.

18. Letters, pp. 386, 406.

19. A. R. Towers, "Sterne's Cock and Bull Story," 18.

20. Kaiser, p. 280 .

21. As Kaiser points out, "the final disillusionment of Don Quixote actually does kill him" (p。295).

22. Miguel de Cervantes Saavedra, Don Quixote, Ozell's revision of the translation of Peter Motteux (New York, 1930), Part II, chap. Ixxiv, p.930. All subsequent references are to this edition.

23. Yorick's references to "mitres" allude to his frustrated hopes for preferment and may well reflect, as Wilbur Cross has suggested (Life, pp. 93-110), Sterne's own bitterness in being discriminated against in ecclesiastical circles because of his refusal to continue supporting his uncle's political aspirations in the Church of York.

24. Kaiser, p. 296.

25. In discussing Tristram's "preoccupation with Death," John Stedmond argues that "Death, in the clown's sense, is life's last joke" (p. 123). 
26. See Alan Howes, pp. 4, 13ff., 20ff., 25, 37f., 50, 53, 56f., $71 f ., 77,81,82-83,86,91,103,114,114,121,125,127,136$, $142,145,151,154,171$.

27. Quoted by Howes, p. 83, n. I.

28. The above reference to Death is one of the many which, John Stedmond points out, "weave a sober counterpoint" (p. 122) through Tristram's journey to France. During his voyage across the English channel, for example, Tristram asks the ship's captain if "a man is7 never overtaken by Death in this passage"(TS, 7.2.481). At Montreuil, Tristram says that "Death 。. omight be much nearer me than I imagined" (TS, 7.10.491), and at Boulogne he refers to that "deathlooking, long-striding scoundrel of a scare-sinner who is posting after me" (TS, 7.7.487).

\section{Italics mine.}

30. Bishop Joseph Hall (1574-1656), to whose Occasional Meditations and Self-Conferences Tristram refers in TS, $7 . \overline{13.493, \text { and whom Lansing }}$ Hammond cites as an important influence on Sterne's sermons (Hammond, pp. 125-32), offers a similar reflection on the houses of mourning and feasting: "And why should it be better to go to the house of mourning then /sic7 to the house of feasting?. . . The house of mourning hath here principally respect to a funerall. . a man is - . thus put feelingly in mind of his mortality, which in an nouse of feasting and jollity is utterly forgotten" (Contemplation on the Historical Passages of the Old and New Testaments, quoted by Hammond, p. 131). For notes on Sterne's borrowings from Bishop Hall, see Gardner D. Stout, Jr., "Sterne's Borrowings from Bishop Hall.'s Quo Vadis, ELN, II (1965), 196-200.

31. Paul Fussell, The Rhetorical World of Augustan Humanism (Oxford, 1965), pp. 263-64.

32. As I hope to show, the analogy of Tristram to Paul's "Old Man," together with Sterne's allusions to La Danse Macabre, should justify the extensive treatment accorded Volume VII of Tristram Shandy in this study. In his study of Sterne's critical reception, Alan Howes has shown that Sterne's contemporaries often dismissed Volume VII as a biographical account of his first journey to the Continent from January, 1762 to June, 1764 (Howes, p. 18). One eighteenth-century reviewer, anonymously writing in the Critical Review (January 19, 1765), summarily dismissed Volume VII as "an unconnected, unmeaning, account of our author's journey to France" (quoted by Howes, p. 18). In the twentieth century, as James Work has pointed out (TS, "Introduction," p. Ixiii and TS, p. 484, n. I), Volume VII has traditionally been read as a satiric "burlesque" upon the kind of Grand Tour proposed by the authors of the popular eighteenth-century guide-books. Both Work and Cross (Life, pp. 355-56) share Curtis' 
contention that Volume VII "is in substance a burlesque of the French guide-book of this period, the Nouvelle Description de la France, by Piaganiol de la Force" (Letters, p. 232). To read Volume VII strictly as a biographical account of Sterne's first trip to the Continent, or as a satiric "burlesque," however, is to neglect Sterne's motto to the title page of Volume VII: "For this is not an excursion from it, but is the work itself."

33. Robert P. Miller, "Chaucer's Pardoner, The Scriptural Eunuch, and the Pardoner's Tale," reprinted in Chaucer Criticism, Vol. I (Notre Dame, Indiana, 1960), p.230. Miller's essay (pp 221-224) informatively discusses the Pauline tradition of the "Old Man" versus the "New Man."

34. D. W. Robertson, Jr., A Preface to Chaucer (Princeton, N. J., 1963), p. 333.

35. Work notes that these are terms from piquet "indicating a slight advantage" (TS, P. 491, n. 3).

36. Work notes that these are "terms from piquet signifying complete defeat" (TS, p. 491, n. 4).

37. Cf. TS, 7.9.490: Tristram here wonders aloud "if the belief in Christ" will continue for "these fifty years to come."

38. In A Dictionary of Slang and unconventional English, I (London, 1961), Eric Partridge points out that one of the meanings of "fig" is the female pudendum (274).

39. TS, 7.7.487.

40. "On the vanity of the world and the swift passing of time," Work, TS, P. 20, n. 6 .

41. Work notes that "the verb bouger, to move, budge, $\sqrt{a}$ s in the act of copulation 7 was not in polite usage during the eighteenth century" (TS, p. 510, n。1). Cf. English "bugger." "Boogar," Work notes, is a "phonetic coinage from the French bougre bouger7 or English bugger" (TS, p. 537, n. 2).

42. Partridge lists "to coit" as one of the meanings of the verb knot, and John S. Farmer and W. E. Henly in Slang and its Analogues (London, 1890-1904), IV, 130 cite "to copulate" as an "old" meaning of the verb knot. Farmer and Henly give the following passage from Othello as an example of the sexual meaning of knot: "Keep it as a cistern for foul toads to knot and gender in!" (IV, 11, 60-6I)

43. See D. W. Robertson, A Preface to Chaucer, pp. 130-32, 382, and L84, for a brief treatment of the "Old Dance" and the "New Dance," and the "Old Song" and the "New Song" traditions. 
44. It is interesting to note Robertson's observation that "variations on what may be thought of as a New Dance to accompany the 'New Song' and what was actually called the $101 d$ Dance' were common in late medieval art" and that this "theme . . . remained prominent in art well into the eighteenth century" ( $p .132$ ).

45. Cf. TS, 7.34 .527 where Tristram describes himself as a "person in black with a face as pale as ashes."

46. D. W. Robertson, p. 333.

47. James M。Clark, The Dance of Death in the Middle Ages and the Renaissance (Glasgow, 1950), p。l.

48. Clark points out that "poet and artist alike intended to portray in allegorical form the inevitability of death, and the equality of all men in death" (Tbid., p. lll).

49. Swain, p. 45 .

50. James M. Clark, Hans Holbein's The Dance of Death (London, 1947), p. 27. Clark's "Introduction" to these Hans Holbein woodcuts entitled The Dance of Death, provides a briefer and more general survey of the Dance of Death tradition than does his book-length study noted above (n. 47).

51. Bodleian Library, Douce Portfolio 137, Leaf 443, No. 444 (Frontpiece to Welsford, p. 129).

52. Tristram makes clear that his main purpose in fleeing Death is to gain more time in which to continue his life and opinions when Death knocks on the door of his study at the beginning of Volume VII. After Eugenius concurs with his observation that Death is a "son of a whore" because he entered the world by sin, Tristram says: "I care not which way he enter'd . . . provided he be not in such a hurry to take me out with him--for I have forty volumes to write, and forty thousand things to say and do" (TS, 7.1.480).

53. TS, 7.9.491.

54. Throughout this last section, I will use the abbreviated titles "A Sentimental Journey," "Yorick's Sentimental Journey," and "Journey," interchangeably.

55. Quoted by Stout, p. 18 .

56. See Howes, pp. 12-15, 17-19.

57. Stout, "Introduction, " p. 25. 
58. It should be made clear at this point that the "Sentimental Traveller" Yorick is the same character as Parson Yorick in Tristram Shandy insofar as they are both dramatic representations of aspects of Laurence Sterne's character. As Gardner Stout has recently shown, Yorick in A Sentimental Journey is related to what R. S. Crane in "Suggestions Toward a Genealogy of the 'Man of Feeling, " ELH, I (1934), 205-230, has called the "man of feeling." Not only does Yorick display what Crane has called most of the "benevolent sentiments" of "most of the representative 'men of feeling" " (Crane, 229-30), but he displays them with what Stout calls "manifest self-approval" (ASJ, "Introduction," p. 25). In the final analysis, the difference between Parson Yorick of Shandy Hall and the "Sentimental Traveller" Yorick as masks of Sterne is, I think, one of degree not kind: the former is a more jestful than "sentimental" dramatic representation of Sterne; the latter, a more "sentimental" than jestful dramatic representation of the novelist.

59. While this entire section of my study is greatly indebted to Stout's "Introduction," I disagree with his contention that "by sending Tristram on a Shandean variation of the Grand Tour governed by the principles of laughter and good humor, rather than by spleen, Sterne took an important step toward Yorick's Journey" ("Introduction," p. 11).

60. McKillop, The Early Masters of English Fiction, pp. 215-16; Stout, "Introduction," pp. 24-28.

61. As Stout points out in an explanatory note, "England and France were. . . engaged in the Seven Years War" at the time of Yorick's journey through France, thereby necessitating his procurement of a passport in order to continue traveling and avoid imprisonment (p. $192 \mathrm{n})$.

62. "Instituted in 1693 by Louis XIV, the Order of St. Louis was awarded to Catholic officers for distinguished military service" (Stout, p. $209 \mathrm{n}$ ).

63. Putney, "Laurence Sterne: Apostle of Laughter," p. 168.

64. Cf. Sermons, I, 122: "Consider slavery--what it is,--how bitter a draught, and how many millions have been made to drink of it; --which if it can poison all earthly happiness when exercised barely upon our bodies, what must it be, when it comprehends both the slavery of body and mind?" (cited by Stout, p. $199 \mathrm{n}$ ).

65. Rufus D. S. Putney, "The Evolution of A Sentimental Journey," PQ, XIX (1940), 367.

66. Tbid., 368 .

67. Kaiser, p. 8 . 
68. Stout notes that Steme paraphrased this passage from II Samuel 12.3 (Stout, p. $275 \mathrm{n}$ ).

69. See Hammond, pp. $94-98$.

70. Stout notes that Sterne paraphrased here from Luke 10.33-34: "But a certain Samaritan, as he joumeyed, came where he was: and when he saw him, he had compassion on him, And went to him, and bound up his wounds, pouring in oil and wine" (quoted by Stout, p. $276 \mathrm{n})$.

71. Putney, "The Evolution of A Sentimental Journey," 365.

72. Stout, p. $278 \mathrm{n}$.

73. Erasmus, The Praise of Folly, p.172.

74. For a study of the feast of agape in the primitive Church, see Richard Lee Cole, Love-Feasts: A History of the Christian Agape (London, 1916).

75. "Follow Peace," Sermons, II, 223. I am again indebted to Stout for pointing out the similarity between Yorick's question to the fille de chambre and Sterne's declaration about the "natural bond of brotherhood" between men in the Sermons (Journey, pp。190-91 n)。

76. See p. 160 , above.

77. Kaiser, p. 180 。

78. In chap. 7 of Book III, Pantagruel says to Panurge: "Everyone is full of his own ideas, especially on external, peripheral, and indifferent matters, that are neither good nor bad in themselves because they do not proceed from our hearts and minds, which are the factory of all good and all evil" (R., 3.7.306). Cf. Hamlet, II, ii, 255-57: "there is nothing either good or bad but thinking makes it so" (quoted by Kaiser, p. 180). 
Amiot, François. The Key Concepts of St. Paul. Translated by John Dingle. New York, 1962.

Anonymous. "An Homily of Almsdeeds and Mercifulness Toward the Poor and Needy." In The Two Books of Homilies Appointed to be read in Churches. Oxford, 1859.

- "A Sermon of Christian Love and Charity, in two Parts." In The Two Books of Homilies Appointed to be read in Churches. Oxford, 1859 .

Apocrypha, or, Non-Canonical Books of the Bible. The King James Version. Edited by Manuel Komroff. New York, 1937.

Augustine, Saint. The City of God. In The Basic Writings of St. Augustine, Edited by Whitney J. Oates. 2 vols. New York, 1948.

- The Divination of Demons. Translated by Charles T. Wilcox, M. M. and Others. In The Fathers of the Church. Edited by Roy Joseph Deferrari. Washington, D C.,1947-。 Vol. XXVII.

- Letters (83-130). Translated by Sister Wilfrid Parsons, S.N.D. In The Fathers of the Church. Edited by Roy Joseph Deferrari. Washington, D.C., 1947-. Vol. XVIII.

- Letters (131-164). Translated by Sister Wilfrid Parsons, S.N.D. In The Fathers of the Church. Edited by Roy Joseph Deferrari. Washington, D. C., 1947-. Vol. XX.

- Letters (165-203). Translated by Sister Wilfrid Parsons, S.N.D. In The Fathers of the Church. Edited by Roy Joseph Defarrari. Washington, D. C., 1947-. Vol. XXX.

- "On the Resurrection of the Body, against the Pagans." Translated by Sister Mary Sarah Muldowney, R.S.M. In The Fathers of the Church. Edited by Roy Joseph Deferrari. Washington, D. C., 1947-. Vol. XXXVIII.

Bibliorum Sacrorum. Iuxta Vulgatum Clementinam. Nova Editio. The Vatican, 1959. 
Blanchard, Rae. "Introduction" to The Christian Hero. Edited by Rae Blanchard。 London, 1932。

Boas, George. Essays on Primitivism and Related Ideas in the Middle Ages. Baltimore, 1948.

The Book of Common Prayer, and administration of the sacraments, and other rites and ceremonies of the church, according to the use of the Church of England. London, 1762 .

Boswell, James. The Life of Samuel Johnson, LL.D. Edited by George Birveck Hill. 6 vols. Oxford, 1934-1950.

Cervantes, Saavedra, Miguel de. Don Quixote. Ozell's revision of the translation of Peter Motteux. The Modern Library edition. New York, 1930.

Clark, James M/idley7. "Introduction" to The Dance of Death by Hans Holbein. London, 1947.

Clark, James M/idley]. The Dance of Death in the Middle Ages and The Renaissance. Glasgow, 1950 .

Cole, Richard Lee. Love-Feasts. A History of the Christian Agape. London, 1916.

Cope, Jackson I. Joseph Glanvill: Anglican Apologist. St. Louis, 1956.

Crane, Ronald S. "Suggestions Toward a Genealogy of the 'Man of Feeling," ELH, I (1934), 205-230.

Cranz, F。 Edward. "Saint Augustine and Nicholas of Cusa in the Tradition of Western Christian Thought, " Speculum, XXVIII (1953), 297-316.

Cross, Wilbur L. The Life and Times of Laurence Sterne. Third Edition. New Haven, Conn., 1929.

Curtis, Lewis Perry. Anglican Moods of the Eighteenth Century. New Haven, Conn., 1966.

Cusanus, Nicolas. Of Learned Ignorance. Translated by Germain Heron. New Haven, Conn, 1954.

da Todi, Jacopone. "How It Is The Highest Wisdom To Be Reputed Mad For The Love of Christ." Translated by Mrs. Theodore Beck. In Jacapone da Todi: A Spiritual Biography. By Evelyn Underhill. London, 1919. 
Dyson, A. E. "Sterne: The Novelist as Jester," Critical Quarterly, IV $(1962), 309-320$.

Edie, James M. "Faith as Existential Choice." In Christianity and Existentialism. Edited by William Earle et al. Evanston, IIl., 1963.

Ellis, Earle E. Paul's Use of the Old Testament. Edinburgh, 1957.

Erasmus, Desiderius. The Praise of Folly. Translated by John P. Dolan. In The Essential Erasmus. Edited by John P. Dolan. New York, 1964.

Farmer, John S., and W. E. Henley, eds. Slang and its Analogues, 7 vols. London, 1890-1904.

Fenelon, François de Salignac de la Mothe. Dialogues on Eloquence. Translated and edited by Wilbur Samuel Howell. Princeton, New Jersey, 1951.

Fluchere, Henri. Laurence Sterne. From Tristram to Yorick. An Interpretation of 'Tristram Shandy.' Translated and abridged by Barbara Bray. London, 1965.

Fussell, Paul. The Rhetorical World of Augustan Humanism. Oxford, 1965.

Gilson, Etienne. Reason and Revelation in the Middle Ages. New York, 1938.

Hall, Joan Joffe. "The Hobbyhorsical World of 'Tristram Shandy, " MLQ, XXIV (1963), 131-43.

Hammond, Henry. A Paraphrase, and Annotations Upon all the Books of the New Testament. London, 1659.

Hammond, Lansing van der Heyden. Laurence Sterne's 'Sermons of Mr. Yorick.' New Haven, Conn., 1948.

Hnatko, Eugene. "Tristram Shandy's Wit," JEGP, LXV (January, 1966), $47-64$.

Holland, Norman N. "The Laughter of Laurence Sterne," Hudson Review, IX (1956), 422-430.

The Holy Bible. King James Version. Cleveland and New York, 1966.

Howard, Donald R. "The Contempt of the World: A Study in the Ideology of Latin Christendom with Emphasis on Fourteenth Century English Literature." Unpublished dissertation. University of Florida, 1954. 
Howes, Alan B. Yorick and the Critics: Sterne's Reputation in England, 1760-1868. New Haven, Conn., 1958.

James, Philip Overton. The Relation of 'Tristram Shandy' to the Life of Sterne. The Hague, 1966.

Jerome, Saint. B. Pauli ad Corinthios prima. In Patrologiae Cursus Completus. . series latina. Edited by

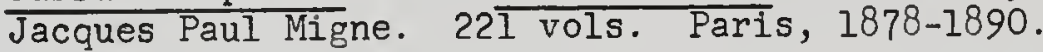

- The Dialogue Against the Pelegians. Translated by John N. Hritzu. In The Fathers of the Church. Edited by Roy Joseph Deferrari. Washington, D. C., 1947-. Vol. LIII.

Jones, Richard Foster. "The Attack on Pulpit Eloquence in the Restoration: An Episode in the Development of the NeoClassical Standard for Prose." In The Seventeenth Century: Studies in the History of English Thought and Literature from Bacon to Pope. Edited by Richard Foster Jones. Stanford, California, 1951.

Kaiser, Walter. Praisers of Folly: Erasmus, Rabelais, Shakespeare. Harvard Studies in Comparative Literature. Cambridge, Mass., 1963.

Kempis, Thomas à. The Imitation of Christ. Translated by Richard Whitford. Edited with an Introduction by Edward J. Klein. New York, London, 1941.

Landa, Louis. "The Shandean Homunculus: The Background of Sterne's 'Little Gentleman. '" In Restoration and EighteenthCentury Literature. Edited by Carroll Camden. Chicago, 1963.

Locke, John. A Paraphrase and Notes on St. Paul's First Epistle to the Corinthians. In The Works of John Locke. 10 vols. London, 1823.

Malebranche, Nicolas. Father Malebranche's Treatise concerning the Search after Truth. Translated by T. Taylor. Oxford, 1694.

Mandel, Oscar. "The Function of the Norm in Don Quixote," MP, LV $(1957-58), 154-163$.

McKillop, Alan Dugald. The Early Masters of English Fiction. Lawrence, Kansas, 1956.

Miller, Robert, P. "Chaucer's Pardoner, The Scriptural Eunuch, and the Pardoner's Tale." In Chaucer Criticism. 2 vols. Notre Dame, Indiana, 1960. Vol. I. 
Milton, John. Paradise Lost. In The Student's Milton. Edited by Frank Allen Patterson. Patterson, N. J., 1930.

Owen, David. English Philanthropy, 1660-1960. Cambridge, Mass., 1964.

Partridge, Eric. A Dictionary of Slang and Unconventional English.

Fifth edition. 2 vols. London, 1961.

Patrick, Symon, et al. A Critical Commentary and Paraphrase on the old and New Testament and the Apocrypha. 4 vols. Philadelphta and New York, 1849.

Pope, Alexander. Correspondence of Alexander Pope. Edited by George Sherburn. 5 vols. Oxford, 1956.

- The Dunciad. Edited by James Sutherland. In The Twickenham Edition of The Poems of Alexander Pope. 6 vols. London, New Haven, Conn., 1963. Vol. V, 3rd ed.

Price, Martin. "Sterne: Art and Nature." In To the Palace of Wisdom. Garden City, N. Y., 1964.

Putney, Rufus D. S. "Laurence Sterne, Apostle of Laughter." In The Age of Johnson: Essays Presented to Chauncey Brewster Tinker. Edited by Frederick W. Hilles. New Haven, Conn., 1949. - "The Evolution of A Sentimental Journey," Prilological Quarterly, XIX (1940), 349-369.

Rabelais, Francois. The Histories of Gargantua and Pantagruel. Translated by J. M. Cohen. Baltimore, 1955.

Rice, Eugene F., Jr. "Nicholas of Cusa's Idea of Wisdom," Traditio, XIII (1957), 345-368.

- The Renaissance Idea of Wisdom. Cambridge, Mass., 1958.

Robertson, D. W., Jr. A Preface to Chaucer. Princeton, N. J., 1963.

Roper, William. The Life of Sir Thomas Moore, Knight. Edited by Elsie Vaughan Hitchcock. London, 1935.

Shakespeare, William. The Tragedy of Hamlet Prince of Denmark. Edited by William Farnham. Baltimore, Md., 1957.

Sherlock, Thomas, D.D. Several Discourses Preached at the Temple Church. London, 1754 .

South, Robert. Twelve Sermons Preached upon Several Occasions.

2 vols. London, 1715. 
Stedmond, John M. The Comic Art of Laurence Sterne: Convention and Innovation in 'Tristram Shandy' and 'A Sentimental Journey.' Toronto, 1967.

Steele, Richard. The Christian Hero. Edited by Rae Blanchard. London, $19 \overline{32 .}$

- The Spectator. Edited by George Aitken. 8 vols. London, 1932.

Stephen, Leslie, and Sidney Lee, eds. Dictionary of National Biography. 22 vols. London, 1855-1900.

Sterne, Laurence. A Sentimental Journey through France and Italy By Mr. Yorick. Edited by Gardner D. Stout, Jr. Berkeley, Los Angeles, 1967.

- The Letters of Laurence Sterne. Edited by Lewis Perry Curtis. Oxford, 1935.

- The Life and Opinions of Tristram Shandy, Gentleman. Edited by James A. Work. New York, 1940.

- The Sermons of Mr. Yorick. 2 vols. In The Shakespeare Head Press Edition of The Writings of Laurence Sterne.

7 vols. Oxford, New York, 1927.

- The Writings of Laurence Sterne. The Shakespeare Head Press Edition. 7 vols. Oxford, New York, 1927.

Stout, Gardner Do, Jr. "Introduction" to A Sentimental Journey through France and Italy by Mr. Yorick. Edited by

Gardner D. Stout, Jr. Berkeley, Los Angeles, 1967.

- "Some Borrowings in Sterne from Rabelais and Cervantes," English Language Notes, III (1965), 111-117.

- "Sterne's Borrowings from Bishop Joseph Hall's Quo Vadis," English Language Notes, II (1965), 196-200.

Swain, Barbara. Fools and Folly During the Middle Ages and the Renaissance. New York, 1932.

Swift, Jonathan. Gulliver's Travels. Edited by Robert A. Greenberg. New York, $\overline{1961 .}$

Tave, Stuart M. The Amiable Humorist: A Study in the Comic Theory and Criticism of the Eighteenth and Early Nineteenth Century. Chicago, Illo, 1960. 
Tertullian. The Body of Christ. Translated by Dr. Holmes. In The Ante-Nicene Fathers. Edited by Alexander Roberts and James Donaldson. 10 vols. Buffalo, N. Y., 1885-1896.

Towers, A. R. "Sterne's Cock and Bull Story," ELH, XXIV (1957), 12-29.

Traugott, John. Tristram Shandy's World: Sterne's Philosophical Rhetoric. Berkeley, Los Angeles, 1954.

Tuveson, Ernest. "Locke and Sterne." In Reason and the Imagination: Studies in the History of Ideas, 1600-1800. Edited by J. A. Mazzeo. New York, 1962.

Underhill, Evelyn. Jacapone da Todi: A Spiritual Biography. London, 1919.

Welsford, Enid. The Fool: His Social and Literary History. London, 1935.

Whitby, Daniel. A Paraphrase and Commentary upon all the Epistles of the New Testament. London, 1700.

Williams, Aubrey L. Pope's 'Dunciad': A Study of its Meaning. London, 1955.

Work, James A. "Introduction" to The Life and Opinions of Tristram Shandy, Gentleman. Edited by James A. Work. New York, 1940.

Wycherley, William. Works. Edited by Montague Sumers. 4 vols. Soho, 1924.

Zanta, Leontine. La Renaissance du Stoicisme au XVI Siecle. Paris, 1914. 
Byron Petrakis was born in Haverhill, Massachusetts on September 2, 1941. After graduating from Haverhill High School in June, 1959, he entered Colby College, Waterville, Maine in September of the same year. In 1963 he received his B.A. degree from Colby and entered the University of Florida to do graduate work in English. He worked as a graduate assistant in the Department of English until April, 1965, when he received his M.A. degree in English from the University of Florida. From 1965 to 1967 he was an interim instructor in English at the University of Florida while pursuing his work toward the degree of Doctor of Philosophy. In September, 1967, he became an Instructor of English at the University of Kentucky。

Byron Petrakis is married to the former Gayle Speliotis. 
This dissertation was prepared under the direction of the chairman of the candidate's supervisory committee and has been approved by all members of that committee. It was submitted to the Dean of the College of Arts and Sciences and the Graduate Council, and was approved as partial fulfillment of the requirements for the degree of Doctor of Philosophy.

August, 1968

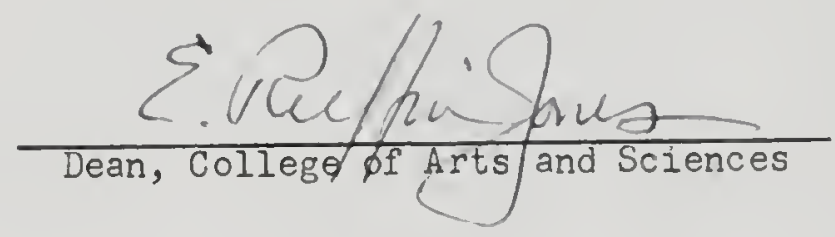

Dean, Graduate School

Supervisory Committee:
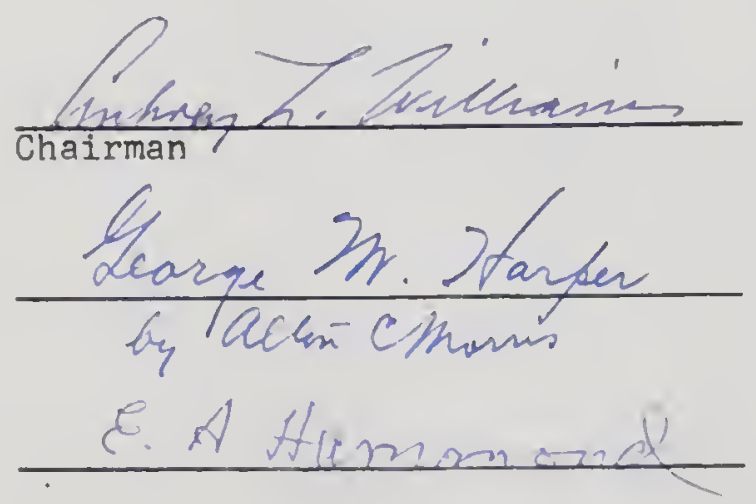
6015 